\title{
ÜBER DIE FREQUENZVERSCHIEBUNG NACH DER TYMPANOPLASTIK
}

\author{
Von \\ Miсніко GOMI \\ Aus der Universitätsklinik für Hals-, Nasen. und Ohrenkrankheiten in Nagoya
}

(Vorstand: Prof. Dr. S. Goto)

Der postoperative Hörschwellenwert in verschiedenen Stadien wurde nach der Tympanoplastik gemessen, um einige Mechanismen der Hörverbesserung nach der Operation zu erklären.

Die Ergebnisse sind folgende:

1) Eine Woche nach dem Eingriff zeigte sich bei jedem Fall im ganzen Frequenzbereich, besonders deutlich im oberen, ein Absinken der Hörsch. wellenkurve ohne Innenohrschädigung. Darauf kehrte die Hörschwellenkurve innerhalb vier Wochen allmählich zum praeoperativen Wert zurück oder die Hörschwellenkurve ging bei einigen Fällen über den praeoperativen Wert hinaus und hielt sich ungefähr vier Wochen lang bis sie zu diesem Wert zurückkehrte.

2) Bei vielen Fällen wurde durch Erhaltung der gesunden Gehörknöchelchenketten bei der Operation ein unter $30 \mathrm{db}$ Hörverlust und besserer Hörgewinn erreicht.

3) Der postoperative Schwellenwert im Mitteltonbereich blieb in den meisten Fällen über ein
Jahr nach der Operation stabil, dagegen zeigte der Schwellenwert in tieferem und höherem Tonbereich weiter Veränderungen.

4) $50 \%$ aller Fälle kamen dem experimentellen theoretischen Schwellenwert nahe, aber bei einigen Fällen, obwohl bei denen die drei Gehörknöchelchen erhalten waren, ergaben sich etwas schlechtere Resultate.

5) Bei den Fällen, die vor der Operation über $60 \mathrm{db}$ Hörverlust zeigten, wurden keine guten postoperative Resultate festgestellt.

6) Die Beschaffenheit des Neutrommelfells ist vermutlich eine der Ursachen für den schalleitungsbedingten Hochtonverlust nach der Operation.

Das zeigte sich durch Vergleichung und Untersuchung der postoperativen Verläufe und der verschiedenen Operationsmethoden.

Gegenstand künftiger Forschungen wird sein :

1) Der postoperative Zustand der Gehörknc̈chelchenketten.

2) Beschaffenheit des Neutrommelfells.

\section{鼓室成形術による周波数移動についての研究}

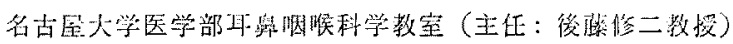

$$
\text { 五 味道年 }
$$

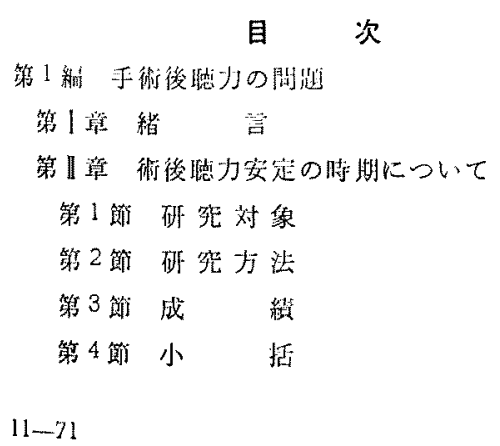

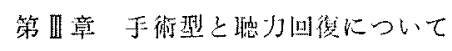

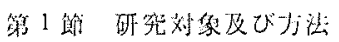

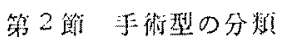

第 3 節 成㮰

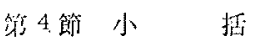

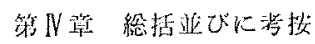

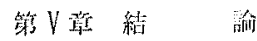

第 2 秒術後埴力周波数特性について 


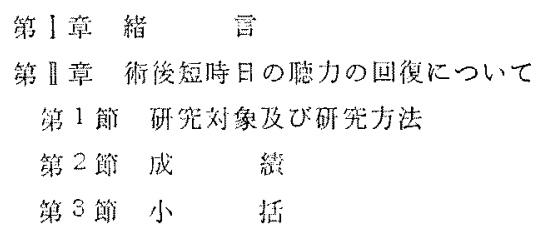

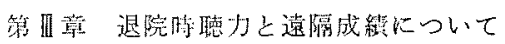

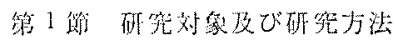

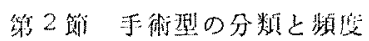

第3節 成热

i) 退院特恥力について

ii) 1 年後の媤加について

第4 節 小括

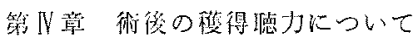

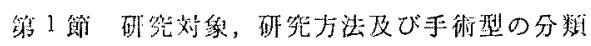

第2 籍 成粈

i) 在例の分粸及びその此度

ii) 聎力像について

符了解小括

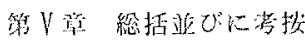

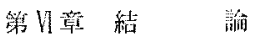

第了編 伝音䧛碍による高音低下について

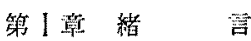 \\ 第】慞 監床例による研究 \\ 第 1 節 研究対象及び研究方法 \\ 第 2 節 成倠

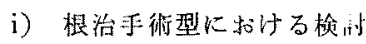 \\ ii) 外耳道保存症例に括ける検討 \\ iii）街後経過に上る高音域の移恥について
}

第3符 小插

第 III章 高音低下の実験的研究

符1節奏跧方法

第 2 節夷龄条件

第 3 節 来䮖成綃

i）上䩳室への硬石露注入

ii) 落膜変化とその回得
a) 喊膛䟝離
b) 跂膜穿孔とその修復

第 4 節 小括

第 N章 総括业びに教按

第、算 結槅

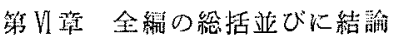

\section{第 1 編 手術後聴力の問題}

\section{第1章 緒言}

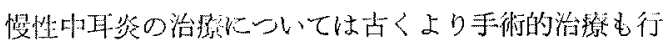
はれ，その手術々式及び治嫄後の聴力像についても幾多 の報告がある。しかるに慢性中耳资惔症性病変である と其に伝音器官の障碍であるがために，その治療を完壁 にするにはこの病变と阽碍の二つを取り除がぱならな

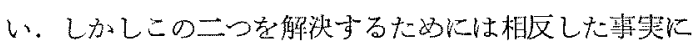
遇遇する事矿少くない，そのために往来小炎症の消失に

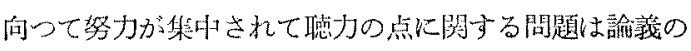
印心となり得なからケ。

この聴力心関する問題が主目標としてとり挙げられた のは1951年からであり，欧州においては Wullstein， Zöllner 等に上り，我が国においては1952年名大後藤 教授によつてこれが行和れ成功を怙さめるに至つた。一

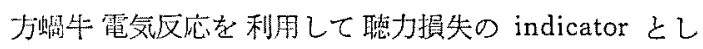

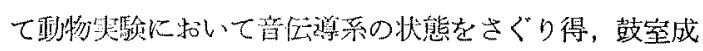
北術発展の上に大きな貣荫をなしたのは Wever, Lawrence \& Smith の実験である.
しかしながら動物缺験により得られた垁験值と臨床的 に鍺室成形術により得られた成績との間にはかなりの相 違がある。更にこの相違の原因を究明する䞒は鼓室成形 術を進歩させる一つの足がかりになると信ずる。

そこで名大耳率咽唤科教空で施行した鼓室成形術後患

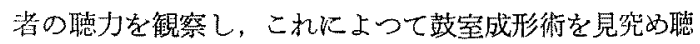
力改善についてなんらがの因子を見出さんとしたのが本 論文の目的である。

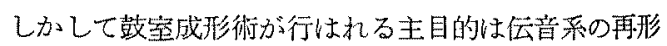
成であり，それに基つく槙力の回復にある，伝望系の再 形成の問題は慢性中耳炎に虬いてはその病変が複雑であ るばかりでなく，症例によつて相違するので単純ではな い，裁膜緊張部を残存世しめ得る症例もあり，又耳小骨 を残存せしめ得る症例もある、病変の诸明である場合は 蹬骨をも術中発見できない例字ある。跂室を正常の状態 に近づければしからざるものより恥力の回復を期待で きると考えるのは労識的ではある。しかしこうして種々 の手術操作を施行し，夫々の術後絟過から得られた聴力 
像を目の前にして，これら聴力は安定した状態にあるか 又は不安定な状態であるのか，更には安定した聴力像に いていかなる手術操作をなすことが理想であるかが新 しい問題となってくるのは当然であり，我々の教空では 䩳室成形術を始めてより数多くの症例についてその聴力 回復状熊を钼察してきている．教室の研究によれば鼓室 成形術後 1 年に批いて子聴力变動のあることを明らかに しているので，術後 1 年及び 2 年の聴力を比校すること によつてこの点を一層明らかにしようとした。勿論炎症 の消失していない場合は別であるが，術創の治渝と㯖力 の安定はどのような関係にあるか，安定の時期を判定し 得るか，又手術操作の差が安定した㯖力像に反映してい るか、このような問題点を明らかにしてみたいと考えて 篗察したのが本編である.

\section{第 II 章 聴力安定の時期について}

第 1 節 研究対象

研究対象としては昭和 29 年より昭和 31 年にわたつて 名大耳鼻科㸶啒科教室で鼓室成形術を受けた患者で，術 後 1 年及び 2 年後汇術創の状態良好で，からその時期に 聴力検查を施行し得た 45 耳である. 45 耳中男子 26 例， 女子 19 例，右耳 22 例，左耳 23 例で年令は 10 才上り 54 才に及s゙.

\section{第 2 節 研究方法}

術後 1 年の聴力と術後 2 年の聴力を比較するためには 聴力の量的表現を比䩒し易い上うにしなければならな い.そこで聴力を示す方法として $125 \mathrm{c} / \mathrm{s}$ と $250 \mathrm{c} / \mathrm{s}$ を 低音域, $500 \mathrm{c} / \mathrm{s}, 1000 \mathrm{c} / \mathrm{s}, 2000 \mathrm{c} / \mathrm{s}$ を中音域, $3000 \mathrm{c} / \mathrm{s}$, $4000 \mathrm{c} / \mathrm{s}, 8000 \mathrm{c} / \mathrm{s}$ 高音域として三君洋分け，各周波数 の閔值の相加平均值を以つて夫々低音，中音，高音閥值 として代表させた，この值について 1 年後のbのと 2 年 後のものをを比較してその差 $\pm 10 \mathrm{db}$ の範囲内にあるも のを不变, $+10 \mathrm{db}$ 以上のものを聴力低下, $-10 \mathrm{db}$ 以 上のるのを聴力上舁とした。

\section{第 3 節 成 結}

a）低音域の変動について

この成績は表 1 に示す通りである. 即ち 2 年後の方が 1 年後より更に改善しているもの 3 例，不変 27 例，低 下 15 例である. 従つて術後 1 年から 2 年の絽過中に拉 いて，低音域の聴力は変化をきたさないものが多いので あるが，1 年閂に $1 / 3$ に低音域の聴力は低下している。

b）中音域の変動について

この成績は表 2 に示す通りである．即ち 2 年後のもの と 1 年後のむのを比較して上鼠 3 例，不变 36 例，低下

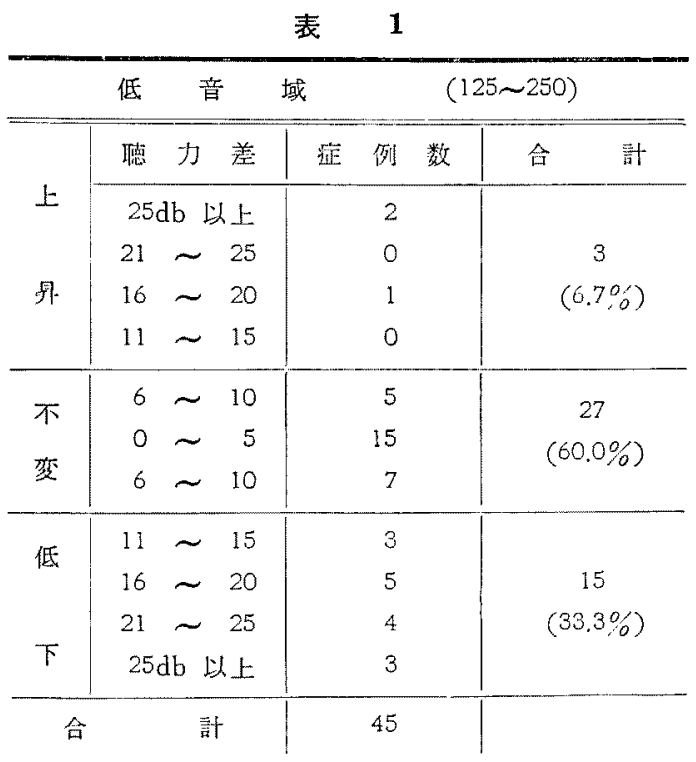

表 $\quad 2$

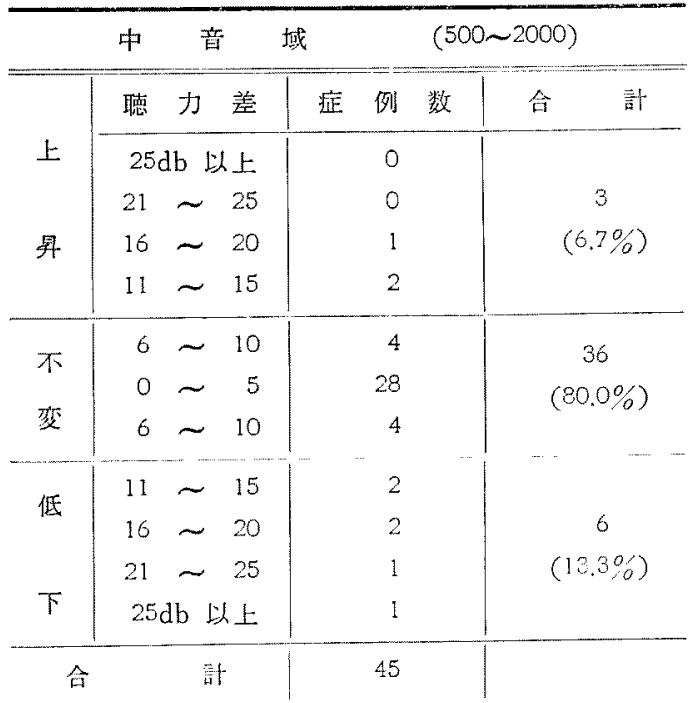

6例である，低音域の变動に比べて不卒例が增加し低下 例が減少している。これにより中音域の周波数に対する 聴力闖值山 1 年後上 2 年後の閂は㱠んど変化をきたさな

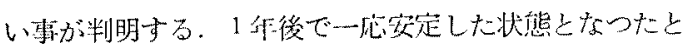
想像さ机る。

c）高音域の変動について

この成績は表 3 に示与通りである。即ち2 作後の值を

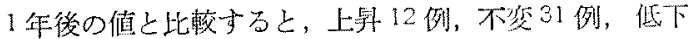
2例となり，上鼠例がかなり多い，この柰は注目すべき 
表 $\quad 3$

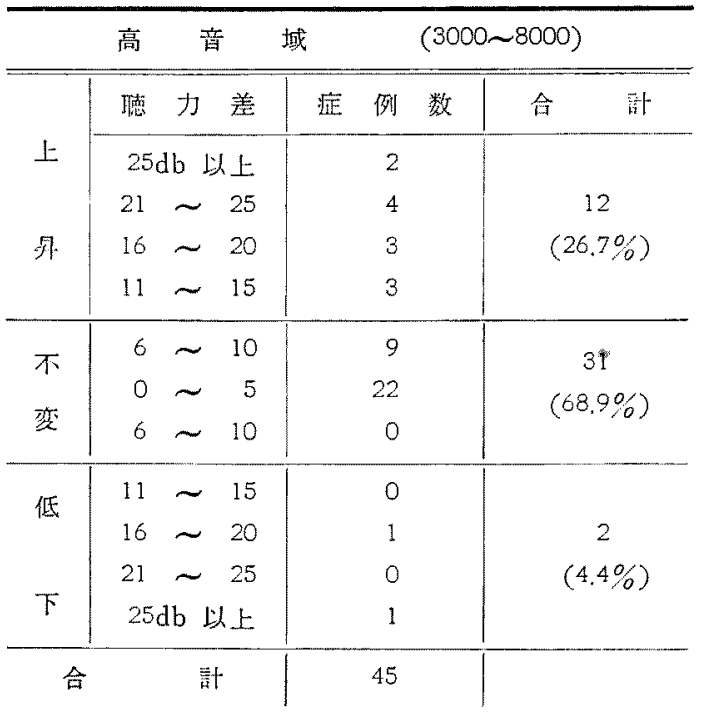

东或で低音域の変動とは全く逆の状態を示している。

又低下例が非常に少くなつているのも特徽である.

d）中音域の低下例について

中音域は日常会話に重要であるので 2 年後の值が 1 年 後の值より低下する例のあることは極めて間題である。 そこで中音域の低下例について特に検索した。症例は6 例ありこれらの低下の原因となり得るものは術前聴力, 手術方法, 手術時の病変, 再愉時所見, 特以耳管病变及 び鼓膜，所謂澵生鼓膛の病变である。この6例の所見そ の他は表4に示してある。

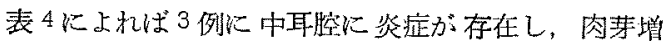
殖，第孔，発赤等を認めている. 又鐙骨の破壞された症 例においては骨獐德力も低下しているので内耳障碍によ

表 4 中音域の低下例

\begin{tabular}{|c|c|c|c|c|c|c|}
\hline & $\begin{array}{l}\text { 衍前 } \\
\text { 聑聴力 }\end{array}$ & 手術方法 & 手 術 归 見 & 現 & & 所 見 \\
\hline 1 & 58 & 䟾室成形 & 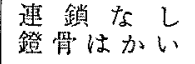 & 良 & & \\
\hline 2 & 68 & " & $\begin{array}{l}\text { 連銷な } \text { し } \\
\text { 鐙骨板のみ }\end{array}$ & $\begin{array}{l}\text { 肉 } \\
\text { 発 }\end{array}$ & $\begin{array}{l}\text { 芽 } \\
\text { 赤 }\end{array}$ & $\stackrel{+}{+}$ \\
\hline 3 & 62 & " & 三耳小骨全欠損 & 良 & & \\
\hline 4 & 37 & " & 耳小骨残 存 & $\begin{array}{l}\text { 穿 } \\
\text { 焱 }\end{array}$ & $\begin{array}{l}\text { 孔 } \\
\text { 赤 }\end{array}$ & $\stackrel{+}{t+}$ \\
\hline 5 & 33 & $"$ & 連 鎖除去 & 良 & & \\
\hline 6 & 47 & " & 建鎖な し & 小穿 & 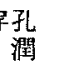 & $(t$ \\
\hline
\end{tabular}

るものと考えられる，以上のように中耳腔に炎症のある もの及び内耳障碍によるものに拈ける聴力の悪化は当然 である. 従つてここで我々の問題とすべきるのは術創の 治瘾状態が良好であるのに低下をきたした2 例である。 しかしてこの 2 例のらち1例は鐙骨も欠除していたるの であり，他の1例は連鎖存在していたものを手術によっ て破墙したものである。この2 例が 1 年経過後に招いて 更に聴力低下した理由として考光得る事は次の事項であ る.

i） 結合織|性硬化が更に進行したのではないか？

ii）形成された鼓膜の性状が変化しているのではない か?

である、しかしこの二つの事項は臨床例に扎いて実証す る事は不可能であり推論するのみである。

第 4 節 小 括

我が教室に打ける鼓室成形術施行例の退院後 I 年閒の 聴力变動を観察して聴力の回復の経過を 6 型に分類した 結果, 術後 1 〜力月で著明に回復するものと，6力月な い乙1 力年にわたつて回復を示するのがあり，郝後短時

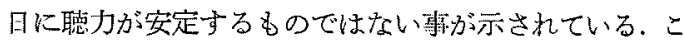
のために術後 1 年及び 2 年の㯖力を比較䂙究した．雨渚 の間值に差を認めない例が 各音域に最も多いのである が，2年経過した後低音域では低下例が，融音域では 上升例が少なからず見られる。この就は術後の中耳腔あ るいは鼓嗼におこつたなんらかの变化が低音に不利で高 旨に有利である事を物語つている。故衍後聴力は 1 年 以上を経過してもな注变化し，その変化は中音域では比 較的安定しているが低音域では变化例が多い，これによ つて 1 年後の中音域の誾波数に刘する聴力は安定した㭙 期のもの之考兄得る。

\section{第 III 章 手術型と聴力の回復について}

第 1 節 研究刘象及び方法

炤和 29 年上り炤和 30 年の 2 年間に名大耳畚咽喉科教 室で鼓室成形術を施行した患者について1年後再検查し， 中耳腔が乾燥し耳漏が停止して経過良好な117耳である。

砸究方法は前章と同様である。

第 2 節 手術型の分類

耳小骨の存否に重点を和いて分類した，先の結果恃第 5 表に示す如く運鎖良好で耳小骨をすべて保存したもの を耳小骨保存型，赖骨はなく砧骨と鐙骨の連鎖良好でそ れを保存したものを砧骨と鐙骨保存型，鐙骨の灭保存し たものを鐙骨保存型としたが，鐙骨保存型を更に 2 型に 分類した１つは連鎖健全であつたが病変除去のために 


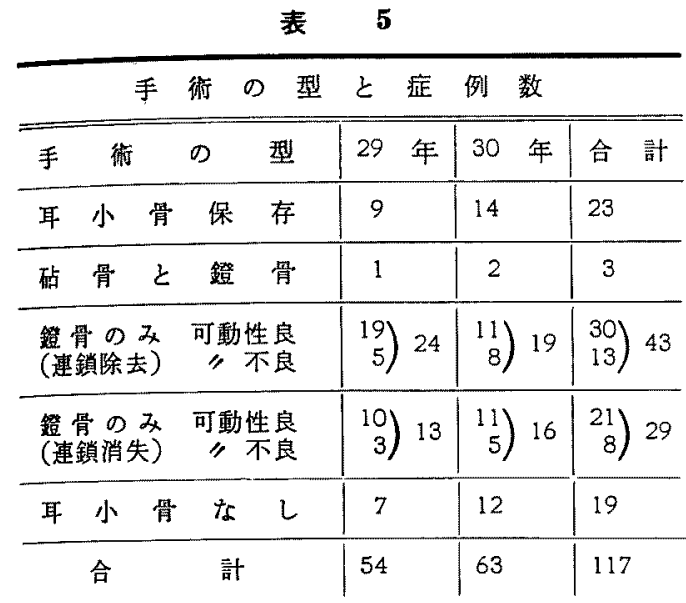

健全な戟骨，砧骨を除去して鐙骨のみ保存した場合で 連鎖除去と記したものであり，他の一つは既にカリェス 等によつて連鎖が謧断されていて竳骨のみ保存した連鎖 消失之記したものである，最後の一群は鐙骨も認められ ない場合で残存耳小骨愉去又はすで飞存在していなか つた例である。

第3節 成績

分類した手術型の頻度も文表 5 に示してある. 30 年 度仙 29 年度に比して耳小骨保存型が增加し 連鎖除去の 例数が減少している。この事は鼓室成形術に対する找術 的な進歩によつて連鎖を保存しても上鼓室の病变を除去 し得られるに至つた事を物語るものである。

a）低音域柿て

衍後 1 年の低音域の変化と手術型との関係を表 6 に示 してある.これによるといずれの型でも聴力回復の割合 が多く $45 \%$ １\% である．聴力低下例は鐙骨の久で連 銧除去のものに多い.

\section{表 $\quad 6$}

\begin{tabular}{|c|c|c|c|}
\hline 聴力 回 复 & 状 態 & （低音域） & \\
\hline 術 & 不 変 & 上 算 & 低 下 \\
\hline 耳 小骨 保 存 23 & $6(2$ & $11(48 \%)$ & $6(26$ \\
\hline 骨のみ（連鎖除去）43 & $10(23 \%)$ & $22(51 \%)$ & $11(26 \%)$ \\
\hline 鉃骨の及（連鎖消失）29 & $12(41 \%)$ & $13(45 \%)$ & $4(14 \%)$ \\
\hline 耳 小 骨な し 19 & $4(21 \%)$ & $9(47 \%)$ & $6(32 \%$ \\
\hline
\end{tabular}

b）中音域について

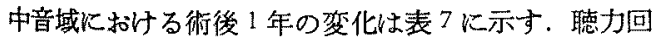
復は 47\% 70\% 亿認めら机 低音域の成績より少しく良

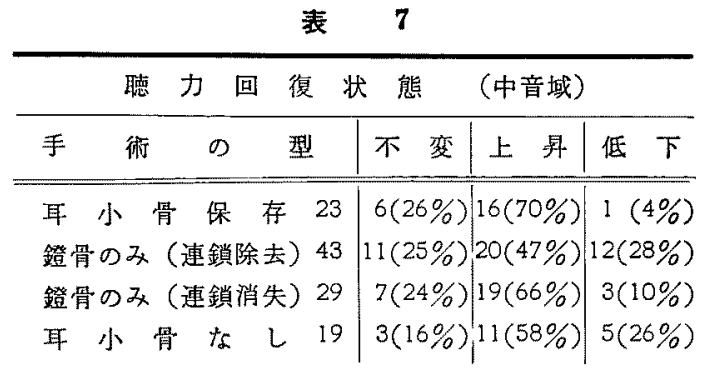

好であり，低下例は低音域より少いが連鎖除去例てお゙い ては低音域と同程度に低下例が多くみられる。

c）高音域について

術後 1 年の高音域の回復については表8に示す. 即ち 聴力良好となつたるのは37\% 65\%であり中音域の回 復と類似している．低下例は全く中音域と同じく連鑈除 去のもの及び鐙骨もないるのに打いて低音域と同程度に 低下例が多く認められる。

\section{表 8}

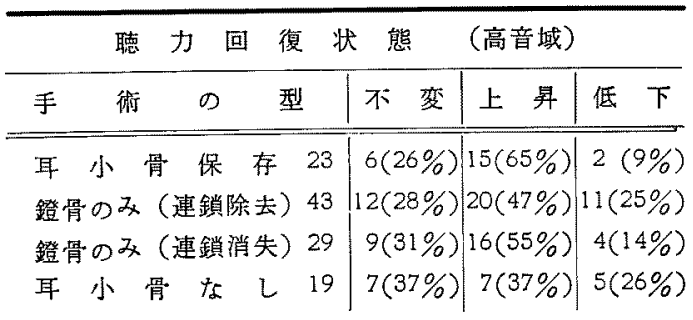

d) 術後 hearing level について

上述の術後聴力の回復の傾向とは別に, 術後何 $\mathrm{db}$ の hearing level であるかが患者にとつては重要である. 即ち術後聴力が低下したものであつても hearing level が $25 \mathrm{db}$ であれば日常会話は支障をきたさないし，聴 力が術後回復したものでも hearing level が $50 \mathrm{db} て ゙$ は支障をきたす。故に実用聴力は社会生活に扎いては非

\section{表 $\quad 9$}

\begin{tabular}{|c|c|c|c|c|c|}
\hline \multicolumn{4}{|c|}{ 聴力が何 $\mathrm{db}$ K達したか } & \multicolumn{2}{|l|}{ （中音域） } \\
\hline $\mathrm{db}$ & $\begin{array}{l}\text { 耳小骨 } \\
\text { 保 存 }\end{array}$ & 砧 骨 & $\begin{array}{c}\text { 鐙 骨 } \\
\text { の灭 } \\
\text { 連鎖除去 }\end{array}$ & 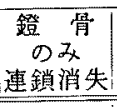 & $\begin{array}{c}\text { 耳小骨 } \\
\text { なし }\end{array}$ \\
\hline $0 \sim 15$ & 2 & 1 & & & \\
\hline $15 \sim 30$ & 9 & 2 & 7 & 4 & 2 \\
\hline $30 \sim 45$ & 10 & & 17 & 13 & 6 \\
\hline $\begin{array}{l}45 \mathrm{db} \\
\text { 以 上 }\end{array}$ & 2 & & 19 & 12 & 11 \\
\hline
\end{tabular}


常に重大である，そこで会話領域としての中音域の実用

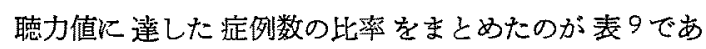
る.

この表によれば耳小骨を゙保存したものは䄪半数が 30 $\mathrm{db}$ 以内の聴力損失に止つているが，連鎖が失はれるに 従つて聴力損失は增大してきている。

\section{第 4 節 小 括}

豉室成形衍は位音系の修復を目的としており，このた めに正常の伝音形態に近づけんとする努力が払はれてい るが，その努力が無駅でない事を数値が示していると洘 える。

術後の聴力回復の点からみて，連鎖健全のbのは䇅す ベきであり，それによつて実用㯖力を保存する症例が增 加し, 鼓室成形術の目的を達すると云う基本線が示され た.

しかし耳小骨連鎖を保存した症例に扎いても亳用聴力 に達しない症例がかなりあり，これは技術的な問題の他 に残存した耳小骨連鎖の中耳伝音機構に扣ける役割及び 新生豉膜の生理学的な問題解決を必要とする。

\section{第 IV 章 総括並ひに考按}

現在においては跂室成形術と中耳根治手術の優劣をと りたてて論義する人はいない，抗生物質の非常な発達。 その使用により一次的植皮の可能性は充分に满足世ら れ，何人の目にもその優位性は認められている.

根治手術後の治痛し難き原因について古来幾多の報告 があるように，鼓室成形術に和いても現在の段階は完全 治瘉の状態に導くにはこの手術をどのよらに発屡させた らよいか，聴力の保持，よりよい致善はいかにしたら得 られるか，更にはその遠隔成續に目が向げられてきてい る事恃周知の通りである。

過去以特いては手術の目的が耳漏の停止，頭蓋内合 併症の预にあつたため中耳根治手術後の聴力について は現在程の data はないが, それです Keen, White, Pressmann, Maxwell \& Richter, Ascherson 等の報 告がある. 又 Stacke 自身も中耳根治手術後の㯖力回復 を咡語検㭗により行つている.

我が国に拈いては，丸山，添野，河辺等の赧告があ り，中耳根治手術において術前德力損失軽度のすのは悪 化する率が多く, 術前悖力損失大なるるのは増進する場 合が少なくないと言う。

これらの報告により中耳根治手術後に执いても少数例 ではあるが奏用的喯力䦪值を有するるののある事の記載 あり，河迅は1953年耳管通気度の 良好なものにかなり
よい聴力を有している事を報告している，又 Wullstein

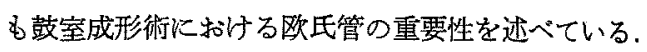
松岡は術啳聴力 $35 \mathrm{db}$ 以上の群では手術創空が比較的 薄く上皮化しているのが $77.8 \%$ ありと記载しているが， 又これが術後婹力を良好にする第１の因子ではないかと も云つている，この薄く上皮化させるのが大腿植皮片に よつて行つている我々の施行している鼓室成形術の特幑 なのである。

従つて根治手術を全く耳の手術としては不用のむので あるときめてしまらのは早計であり, その徹底した病変 の除去は未だ考える余地のあるところである. 又事実慢 性中耳炎においてはその病变によつて手術時に耳小骨を すべて残し得ない症例もあり，根治手術と本質的に異つ ていない場合子ある、しかしながら鼓室成形術後の聴力 については根治手術と異つて伝音形態が変化に富み，舆 味深く検索せねねばならぬ点がそこにある。

A) 聴力安定の時期について

鼓室成形術後の症例についての報告は，この手術の歴 史の浅いところから現在までをれに対する文塥は数少 いこえまで報告された中耳根治手術後の聴力について も, その測定時日が明確に記載されていないるのむあ

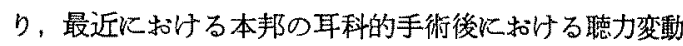

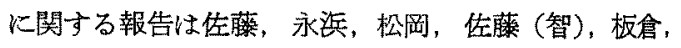
風間，神尾等がある．松岡は手術後 1 年以上経過したも のについて検索し種くの検討を加え，佐藤（智）は術後 1 カ月の聴力像について報告している.

板倉は術後約 1 力年の聴力像を 1 力月毎に再検查し, 聴力の回復状態を 6 型に分類した．術後直らに聴力の固 定する症例や，1〜3力月で変化するむの，更に6力月 ないし1年に至るまて回復する症例のある牙を報告し， 術後 1 力年は聴力は固定し難いものである玡を过ぺてい る.このため私は術後 1 年経過時之 2 年絟過時の聴力を ほ注同一の条件と考光られる状熊で测定した。症例数は 非常に多数であつたが，2 年間観察し得た症例は45例

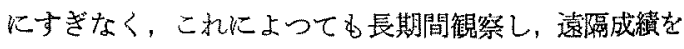
長年にわたつて集める事のいかに困難かを知る、この data から考えられるのは先つ贺一に聴力は常に変動し て扰り，测定誤差も含めて退院時の埴力，術後短時日释 過後の聴力は必ずしも永久的でない雨を示している。半 年から1年の間に変動あり，又更に1年を経過すれば又 変化していくょ5である。唯中音域を形成する周波数に おいて 1 年を経過すれぱ大体安定した閶值をとると考学 られる。しかし低音域と高音域では必ずしもこの考えは 
成り立たす更に变動がある。即ら低音域は低下し高音域 は上昇して行く．Békésy は伝音障偟に対する解秎に stiffness 及び mass なる概念を導入し， stiffness の減 少が $1000 \mathrm{c} / \mathrm{s}$ 以上の高音汶対して最も意味があると述 ベている.ここで stiffness と mass は相反する性質を 有するるのであり， stiffness の減少と mass の㙕加及 び stiffness の增加と mass の減少は同一の現象として 考えられると云う。しからば得られた私の成績からして との場合に执いては中耳腔はその手術的侵愳が加つた場 合，更に 1 年を経過してもな湾化し stiffness の增加 及び mass の減少をきたすのであらうか。これがなに に原因するかを主張すべき確実な実験的根拠を持ち得な w.

以上恃あくまでも統計的な観察結果であり，これらの 問遁については個々の症例について検討する必要を痛感 する．最も安定していると考えられる中音域群の低下例 をとり上げると，耳管狭窄，中耳腔の炎症の存在，術中 の鐙骨の破罗等に注目せねねばならない，中耳腔に资症の 見られる事は豉室成形術が成功しなからた例であり，い がその変化が僅かであるとはい光検討を要する問題で ある. 全く原則諭ではあるが聴力改善の問題はそれ以前 任先つ炎症を消失させるのが先決問題であるのを痛感す る. 又镫骨の破塄は必ず内耳の刺㦸应状をひき扎こして 枋り，これによつて生した内耳障碍は回復し難く 2 年経 過してもな活䒯癖の一途をたどつており，手術時の慎重 な操作を要求せられる．しかしこの 2 年間観察の症例は 昭和 29 年及び昭和 30 年施行のもので，当時は我が教室 に执いては未だ中期の段階にあり，今日に括いては接術 的進歩によつてこの上らな症例は見られで，この問題の 解決は容易である事を知る。

次に中耳腔が良好なるにも拘らず低下をきたしたもの に連鎖鉒去がある．即ち煡全な連鎖があるに拘らず肉芽 除去の操作が不完全となるのを扣それて桘骨，砧骨を除 去したものである、これは次に述べる手術型の種類と聴 力の回復に関係がある.

B）手術型と聴力回復について

聴力回復判定の基潐は報告者によつて夫々の方法がと られて物り必ずしも一定ではない。Fowler は256c/s $\sim 4096 \mathrm{c} / \mathrm{s}$ を平均して $5 \mathrm{db}$ 以上の変動を意味あるるの としてとり上げ，中耳根治手術症例で $5 \mathrm{db}$ 以上增進 19 例, 不変 13 例, $5 \mathrm{db}$ 以上の覀化 13 例を報告している。 河辺は術後の，検查に打いて $5 \mathrm{db}$ 以上の闌值の上昇或い は低下を夫々增進及び悪化とした，大和田等は各周波数
平均で $11 \mathrm{db}$ 以上，又は $3 っ の$ 周波数について $20 \mathrm{db}$ 以上の差があつたとき聴力が变化したと記載しだ、又永 浜等は純音聴力のみならず語音聴力の雨観点にたつて判 定基準の決方学考案し，純音聴力では平均聴力損失 $11 \mathrm{db}$ 以上の変動を, 又語音聴力としては社会適応㐿数 15 以上の変動を基淮に採用している. 松岡は中耳根治 手術後の聴力変動てついて推計学的数值を報告してい る. 佐藤（智）は平均聴力損失値として会話音域平均值 を使用し 純音による成績判定は $\pm 9 \mathrm{db}$ 以内を不变とし た．著者もこれらの基潐を参都し $\pm 10 \mathrm{db}$ 以内を不 变と考えて観察した成績を判定した．しかしこれは平均 聴力損失値であり，変動の原因に多くの因子の含まれる ところから個々の症例について検討すべきでありここの 方向へるつてゆくべきである.

先にむ述べたように昭和 29 年, 30 年は我が教室に括 ける鼓室成形術の中期之も云光る状態であり細かい手術 操作を加えた症例は多くないしいしこのような状態に あつてもこの 2 年間を此較するに，年を追らに従つて耳 小骨を残存させ連鎖は除去しないよらにする努力が払は れている.

C）聴力の回復状態

低音域，中音域，高音域の3群の表に示されている上 うに，特に鼓室成形術型に批、て明らかな如く，耳小 骨の操作に関しては良好な連鎖を除くことは極力さける べきである. Dingley は根治手術の限界について論じ た諭文の中で，手術時の Amboss に重点を执きAmb・ oss 消失例で $91 \%$ に術後聴力增加をきたしているのを知 つて驚き，しかしながらこれらの症例の大多数が手術前 後に低い聴力閔值を有していたため，これにより早期手 術の必要性を強調している，更に彼はその論交の中で A mboss 除去例中 3 例に聴力增進, 3 例聴力低下をき たし，Amboss 保存例では11 例中の2例が術前，術後 共に殆んど正常に近い聴力閶値を示していた事によりそ の成功の原因は Amboss を注意深く残した事により得 たと信じている.

中耳根治手術後の聴力 level については夫今の 報告 があることは既に述べたが，一般的に言つて良好な症例 で 40 50db, 大体 50 60db とみてよいであらう.こ れに反して鼓室成形術では Wullstein は1956 年43 例 の手術例を報告し $45 \%$ K 30db level, ?1\%に $15 \mathrm{db}$ level となり，全症例の $75 \%$ が害用的価值を有する聴力 であつたと述べている，Zöllner は1957年 Wullstein

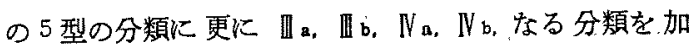


之，特に一型においては94\%にも及ら゙良好な結果を示し ている. 更に Proctor, Schuknecht 等もこれと少らな い結果を出している.

一方 Tauno Palva \& Kari Pulkkine は window. plasty (Wullstein V) を施行した123例について useful hearing に達したものは31\%で pars tensa を 保存すると敨膜欠損の症例に比して41\%と良好になる事 を示している，佐藤（智）の報告に颃いてもI型，四型 は良好な結果を示しているがその結論として最も聴力改 善を期待できるのは術前 41 50db の範囲であり，術 後聴力の社会啇応の立場から見るならぱ，術前 30〜50 $\mathrm{db}$ の場合が非常に有効な成績を期待し得るとしてい る、著者の成續はこれらの成績と此べて悪い，30db以 内の聴力損失澡着いたものは耳小骨保存例に和いてさ え約半数である．乙かし簦骨のみ残存例には $15 \mathrm{db}$ 以 内の損失例の認められない事から耳小骨残存の意義はあ る、最む理想的な伀音修復形態をとつている例におい て，これらの残存した耳小骨連鎖がその役割を充分果し ていないと想像される症例もある.勿諭術前聴力の点も 問題にすべきである事は各々の報告によつても明らかで あるが，連鎖の癒着，離断，或いは植皮片によつて新し く形成されれた膜の性状も考えねばならないＷullstein は新生膜の生理学, 病理学的性質について問題を提起 し，植皮片が新しい膜として使用された場合，ぞのよう
に働くかを解明せねばならないとしているが全くそれに 対する解決を与えてはいない，膜で以つて覆はれた一旦 耳漏停止した中耳腔の構造をおしはかる事は困難であり 手術時の所見をるつて術後の伝音機構をさぐるの㒄理 がある. 新生膜は正常鼓膜とは異り，種々の点に称いて 支持されている膜と考えられ, それが振動体として作用 する際は正常鼓膜より更に複雑な運動をなすであららと 想像される.手術後の伝音形態を追求する事は更に今後 残された課題である。

\section{第 5 章 結 諭}

聴力安定の時期を判定し, 豉室成形術はいかなる手術 型をとる事が理想であるかを知るため長期にわたつて観 察し次の結果を得た。

中音域の周波数に対する聴覚間值は 1 年を経過して始 めて治症と判定すべきである.しかし1年を経過しても な泜音域は低下，高音域は上年する傾向が認められ， この二つの音域に沶いては 1 年後に治瘉安定と判定する のは困難である．

手術型の選択については耳小骨の病变を詳細に観察し 病変の除去が可能ならば連鎖を保存して無理な侵璂は避 けるべきである。これ依つて聴力の上犁が期待され る. 根本的な問題として忘れてならないのは资应の消失 であり、これを度外視して連鎖の保存を論ずる事は無意 味である。

\section{第 2 編術後聴力周波数特性について}

\section{第 I章 舶言}

第 1 編第 』章に括いては鼓室成形術に淤ける聴力全体 の推移をみるために便宜上聴力検查に使用した周波数を 低音域, 中音域, 高音域の3群に分けてとの損失を $\mathrm{db}$ の相加平均値をるつてその音域を代表するものとの仮定 の上にたら研究した，その結果第』章で述べたような結 論へと到着するのであり，鼓室成形術の基本線はここに 示されたと考える.

しかし平均值で代表する事に問題があり，種々の形を とる audiogram を適確に表現しているのではない，又 今迄は術後の聴力变動に重点がおかれてきたが, 術前聴 力損失 $15 \mathrm{db}$ の症例が変動なければ術後 $15 \mathrm{db}$ の㬰用 聴力䦨値を有し, 術前聴力損失 $30 \mathrm{db}$ が $15 \mathrm{db}$ まで改 善された場合と同一の状態になる.しかし後者の場合は 伝音機構の変化は著しいるのがあり同等の価値を有しな い.ここに近年とみに発達してきた microphnicsによ
る中耳伝音機構の障碍実験によつて徐々に解明しつつ, 臨床と実験的中耳伝音形態を結び合はせて考える事は與 味深い。

このような見地から各周波数についての检討及び術後 穕得した聴力 level 飞焦点をあてて検索すると共にこ の聴力が大体何時頃形成されるかを追求した．

第 1 編に拈いては 1 年以上経過した術後聴力について 観察し，この結果同しような手術操作を行つても同じ らな結果を示さず全く異つた像を呈する症例もある。こ の点は術中の観察で同じ所見を呈する病变が術前聴力に おいては差を示し得る事を念頭におかねばならない，又 一方我々の 観察能力の 限度を示しているとる考克られ る. しかし術後の聴力については植皮後の肉芽形成の状 態，皮弁ののせ方等、跾密に計測し得ない大きな壁があ る.それでもなほこの術後聴力がいかなる経過の後に生 れ出るか忙興味あるところである。 
植皮片をのせた時急者は自覚的に㙏力の改盖された事

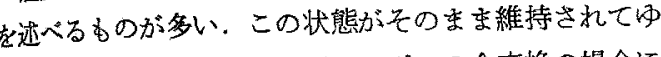
くものなのかしかしガーゼタンポンの全交換の場合に は聴加良否に対寸る閏には確答を与古人は少い。 のため術後 1 週間後にガーゼタンポンの全交愌を施行し てその際に聴力検査を行いその後退院時までの変化を観 察せんとしたのが本編の第1の日的である。

第 20 目的は各手術型相互の関係及びその意㼁を知る うとした．攱室成形術後の聴力の状態を一言で表現する のは不可能化近い，術前の聴力損失，伝音系修復の程度 いかん等によつて全くその条件は異つてくるのである。

及他の一面から考光ると我々の笑生話に括いては散室成 形術後の聴力変動がどの程度に存在するかよりるむしろ

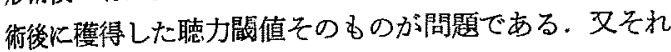
が患者にとつても非常に重要である事は勿論である。

伀音䅸碍については C.M. を指針としてかなりの 範围まで契験的に検索されて抢り，このようにして得ら れた結果を臨床結果に数きか支て考支てみる事もでき る. 㩾室成形術は一般に外耳道の变形, 孚様洞の削開に よる腔の抬大を伴つて扣り，更に部膜の状態の変化なと から敬室成形術後の值をそのまま実鈳值と比較する事に 無理があるけれども，比較観察して術後どの程度の結果 を期待し得るかるみるのが策3の目的である，以上三つ の目的は鼓室成形術においてはきわめて意義ある事と考 亮る。

第 II 章 術後短時日の聴力回復について

第 1 節 䂰究対象及び研究方法

昭和 34 年に名大耳鼻咽知科 教室にて 部室成形術を施 行した13耳である，術前の聴力検査を施行し，鼓室成 形術後 1 週間每にガーゼの全交換を行い聴力検査を施行 し聴力の推移を钼察した。

\section{第 2 節 成績}

13 例を手術型によつて分類した１型4 例、【型1例，

型 5 例，N型了例である。

A) 【型群

No. 1 (図 1)

この症例は弛緩部の穿孔で緊張部を保存せしめたもの

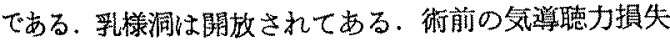
は 20db 前後である、1週間後のガーゼタンポン全交換 時, 聴力像梳音の低下を認め，低，中音は術前と同し

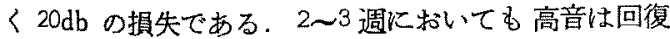
していない，低音の变化は諗めないが高音のみ低下し， 退院時まで遂に回復しない症例である。3週間で退院し
图 1

No. 1

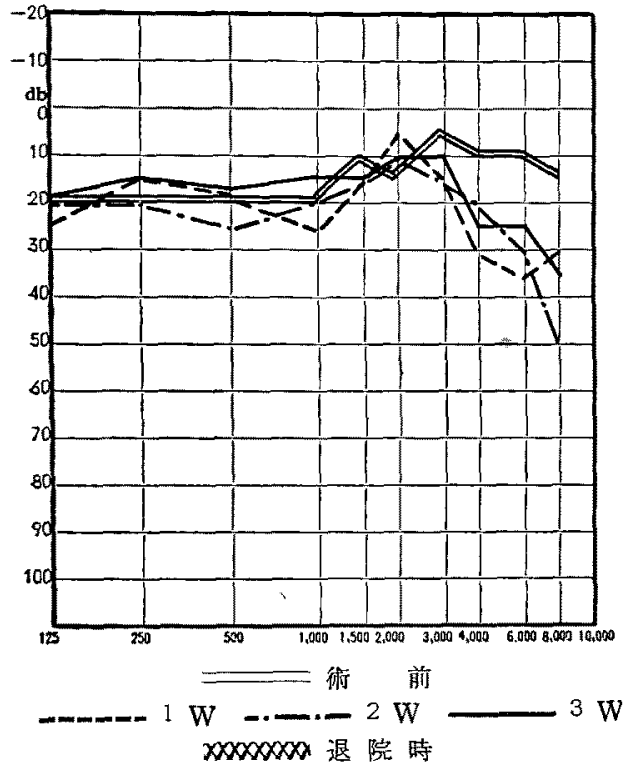

t

No. 2 (図 2)

術前の骨㾞聴力は大体正常である。術中所見は救骨, 砧骨共に正常で固有豉空の粘膜も殆んど肥厚はないが鐙 骨が運動不良であるため可動術を行つたとこる眩䍐を生 した，乳様洞は開放した，䁙最を生したため術後骨導䍡

图 2

No. 2

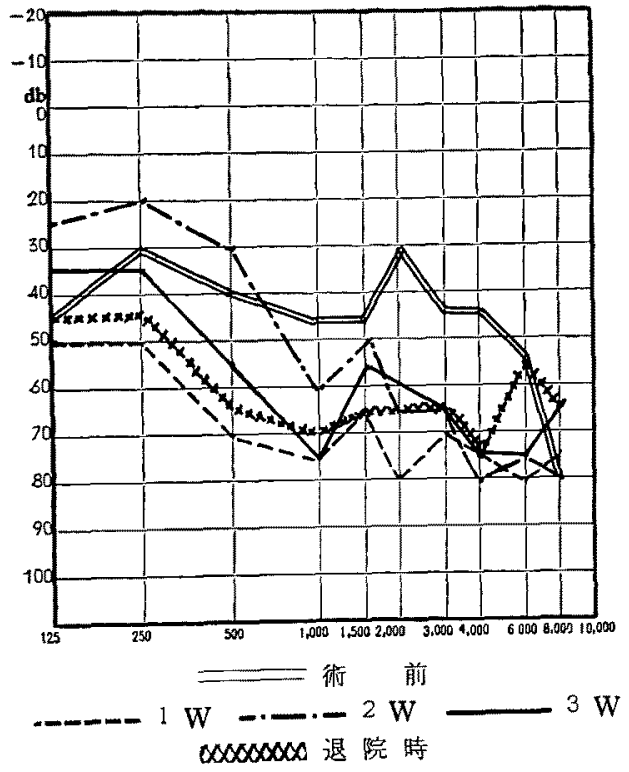


力值は低音て $15 \mathrm{db}$ ，中，高音で 20〜40db の低下を示 した，2 週目に小第孔を認め大が低音の聴力は此較的良 好である. 3週目に小穿孔の部に油絉を貼布するが低音 部の回復はさ汪ど認められない，穿孔を残したまを乾燥 し，術剑の乾喿之同時に 低音部の上昇が認められてい る.

\section{No. 3 (四 3)}

術前の気導聴力損失は 20 30db で実用聴力閶値であ る.この症例も乳様洞は開放してある．鼓膜は大穿孔を 認めたため全部除去し.三耳小骨は保存した。術後 1 週 目骨尊聴力の変動は認められないが気尊聴力は全体に低 下し，40db 前後となつた. しかし2週後に扣いては $2000 \mathrm{c} / \mathrm{s}$ までの低, 中音部は術前の 值までと回復した が，高音部の回復は余り良好ではない，ところが 3 週目 に至つて高音部も含めて術前と同じレベルにまで回復し て実用聴力闒値となつている。

\section{図 3}

No. 3

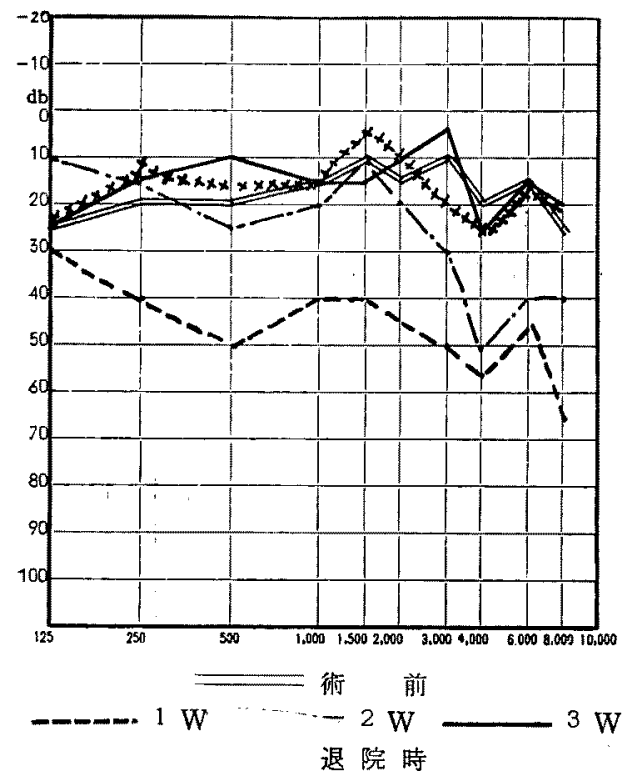

No. 4 (図 4)

乳様洞を開放し，残存揊膜を全部除去して三耳小骨は 保存し，植皮片をのせた症例である，骨導聴力低下は認 められない，術後 1 週目は高音の 低下のみが著明であ る. 2 週目に高音の低下が更に著明となつたが，3週目 には高音も回復し，4週目には聴力は安定してゆく傾向 にある。
図 4

No. 4

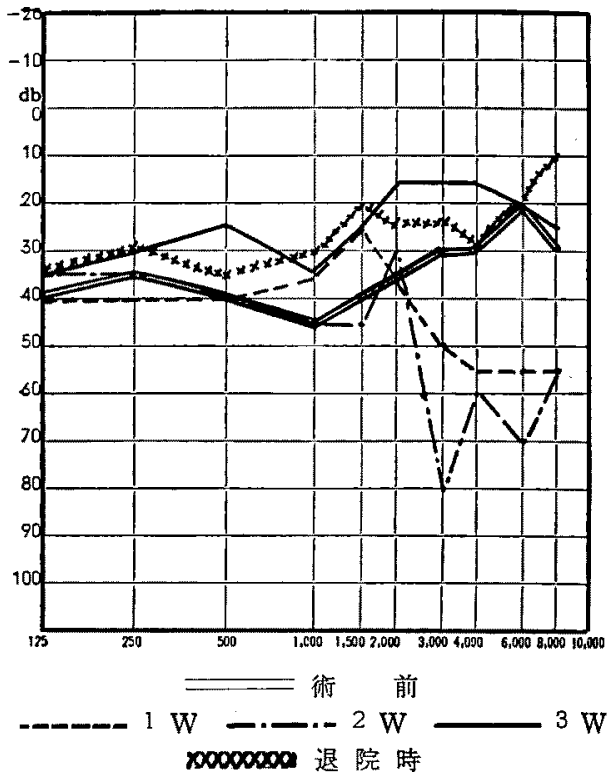

No. 5 (図 5)

この症例は乳様洞を開放し，桘骨がすでに欠存してい ていたため，砧骨と鐙骨を残存させたものである，術前 すでて低音域の聴力損失が著明である。1 週目聴力は一 様に軽度低下している，2 週目には $500 \mathrm{c} / \mathrm{s}$ 以外明明 が回復している．３週目には少しく一様に低下し術前

图 5

No. 5

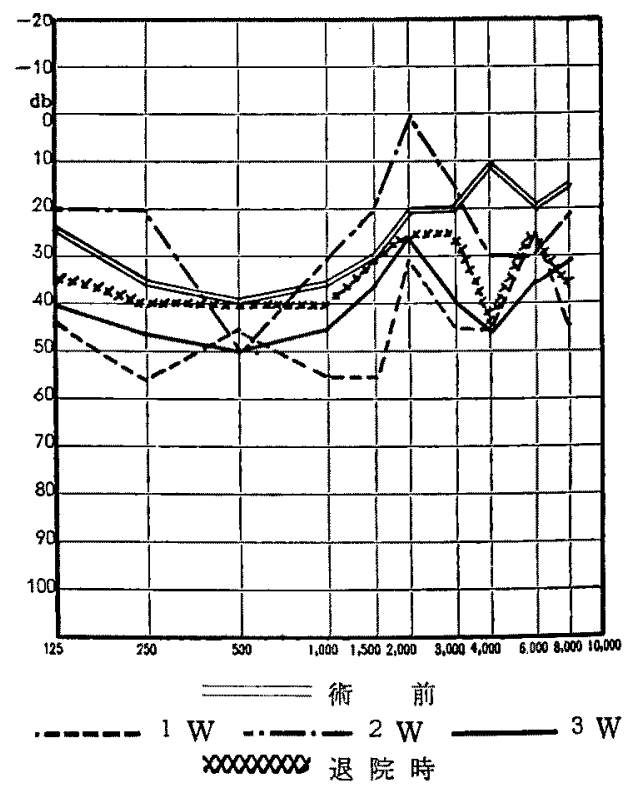


と同程度までに 回復しているが，高音は回復していな い.

\section{No. 6 (図 6)}

この症例は三耳小骨は残存していたが肉著除去の操作 が不完全となるため連鎖を除去し，乳様涧を開放した症 例である.術後 1 週目は聴力は低下したが，2 週目には 回復に向い，3週，退院時には $30 \mathrm{db}$ 損失 まで回復し たが高音は回復しない。

图 6

No. 6

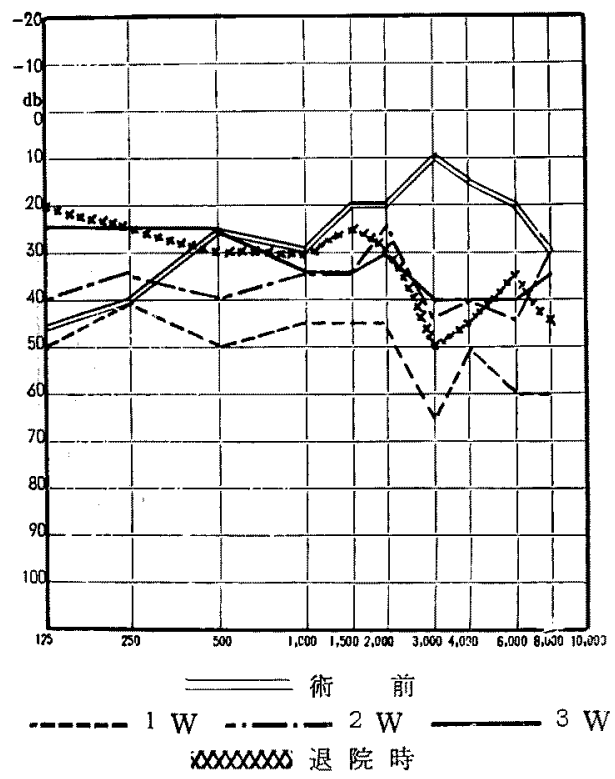

No. 7 (図 7)

乳様洞を開放し，砧鐙関節の離断によつて鐙骨のみを 残存せしめた症例である. 1 週後の聴力は 5〜20db 低 下しているが，2〜3週目にはそれか゚更に低下をきたし た.しかし 4 週目に至り術前及びそれ以上に回復した.

No. 8 (図 8)

墭骨，砧骨健全なるも除去し鐙骨の久残存せしめた症

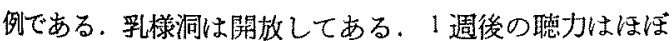
術前と同しであり，2週には中音部 10〜20db 良好とな り 3 週後には術前と同程度にまで再び低下したが，退 院特性中音部が 2 週の時より更に良好で $1000 \mathrm{c} / \mathrm{s}$ 及び $2000 \mathrm{c} / \mathrm{s}$ は $10 \mathrm{db}$ 損失まで回復しているが高音は常に殆 んと変化していない．

No. 9 (困9)

乳様洞を開放し，槌骨頭除去，砧骨脚消失し連鎖離断 あり，鐙骨は健在であつたが操作により前脚の骨折をひ
图 $\quad 7$

No. 7

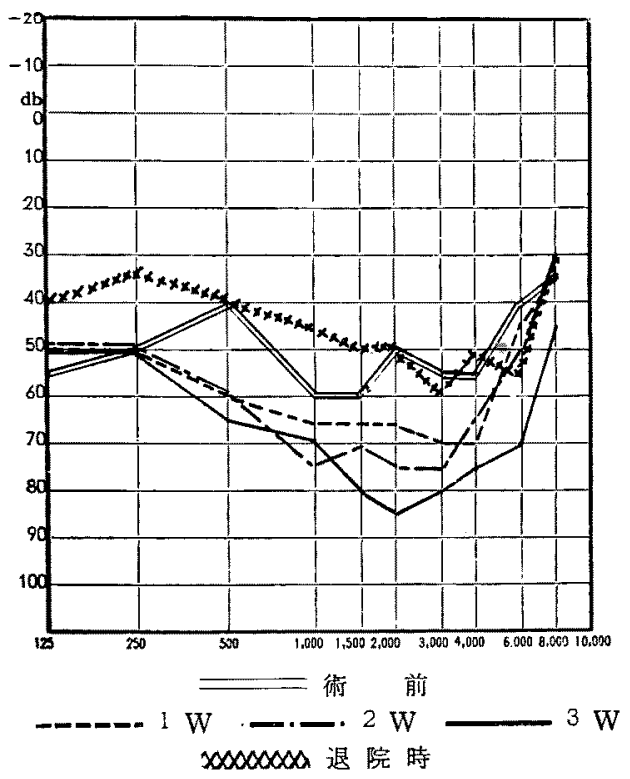

图 8

No. 8

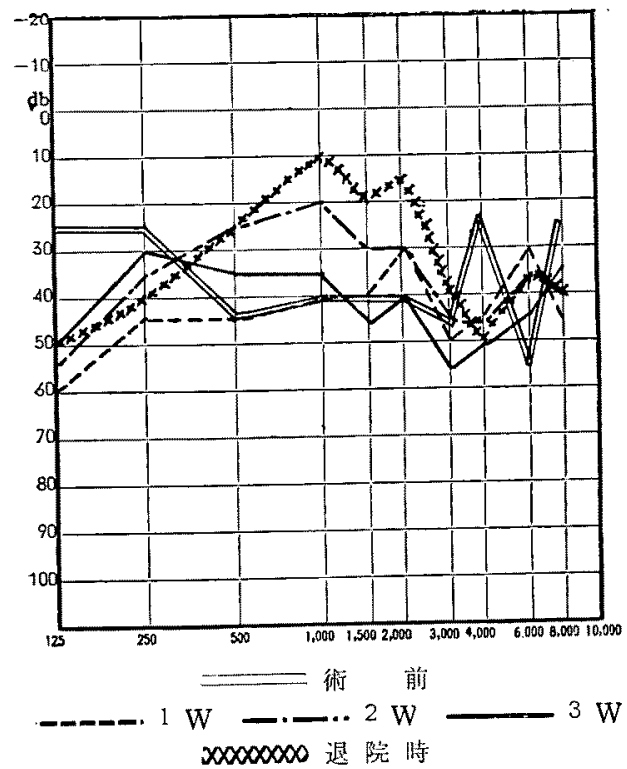

きおこした。しかし眩最は生ぜず 1 週後の骨尊聴力にも 低下は認めていない。しかし気導㯖力は 1 週後低下を認 めている。汸 2 週後よりすぐに回復が始まり鐙骨の操作 上の問題点があるに拘らず，高音の回復が蓄明であり退 院時には術前と同程度まで回復した。 
图 9

No. 9

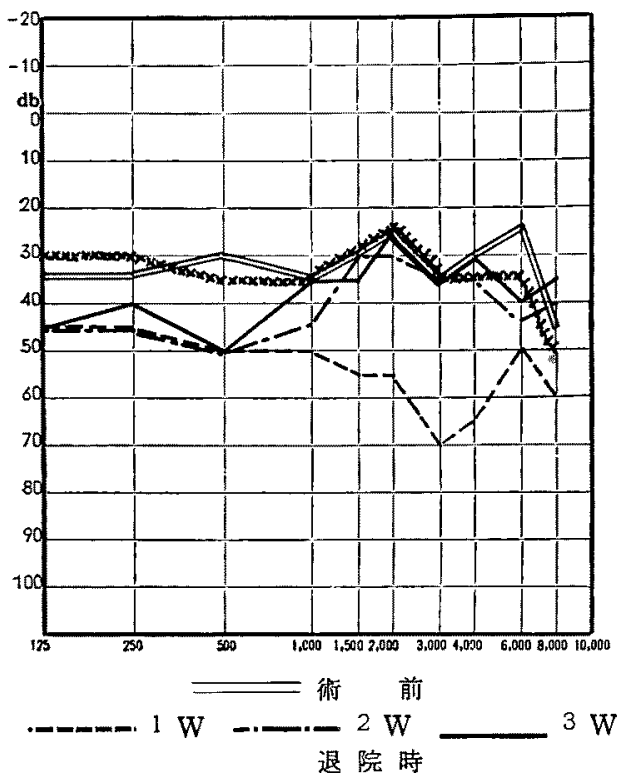

No. 10 (㘡 10)

中耳根治手術後の再手術症例で内耳炎を合併し骨導聴 力に $40 \mathrm{db}$ 前後の低下を認めている。

鐙骨は残存しているが高音が低下し退院時まで回復し ない、合併症の存在から理解できる症例である。

図 10

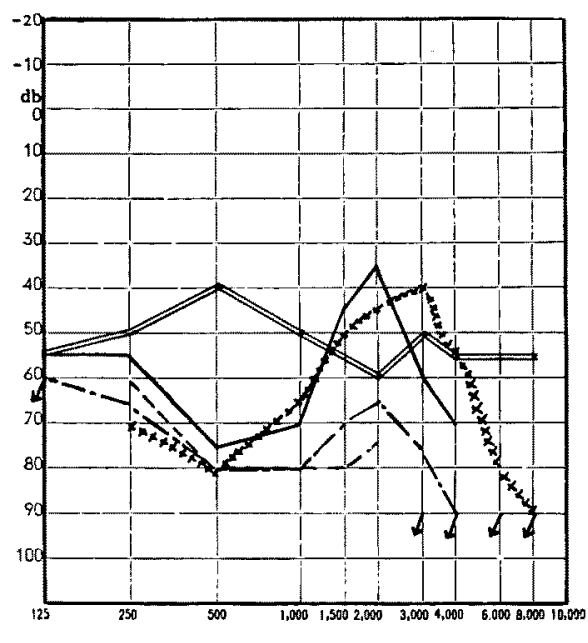

前

$1 \mathrm{~W} \cdot-2 \mathrm{~W}$ 100000000 退院時
No. 11 (図 11)

この症例は真珠腫で水平半規管に瘦孔の形成あり．骨 導聴力も著明な低下を認めている。

このよらな条件にも拘らず，すで週間後に聴力の 上昇を見ている，聴力は安定する様子をみせていない が，術創の治癒経過よく3週間で退院した症例である.

图 11

No. 11

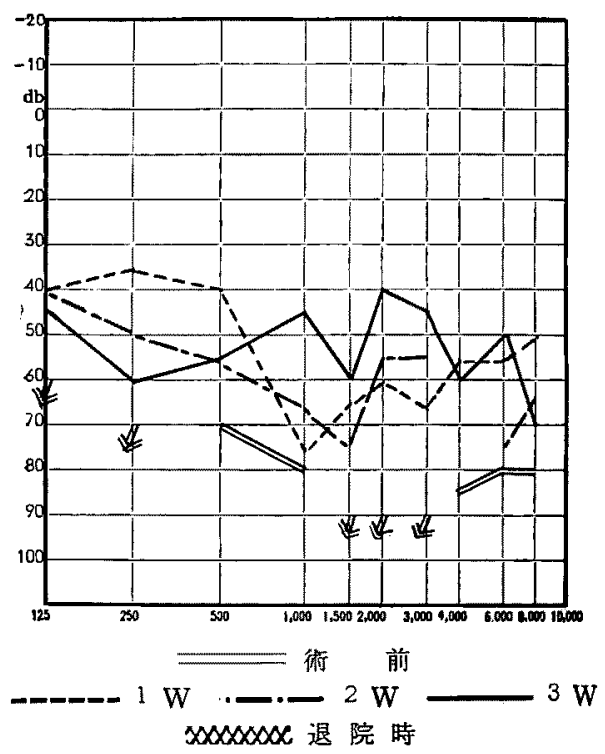

图 12

No. 12

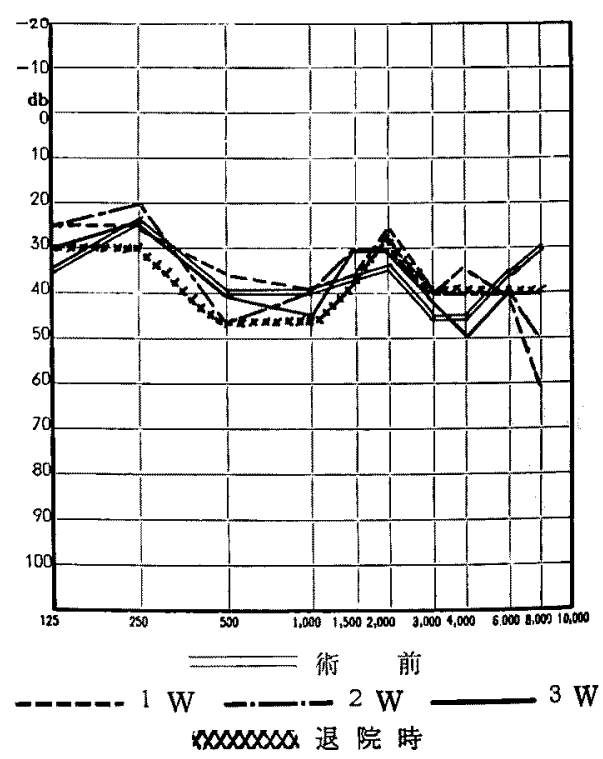


No. 12 (図 12)

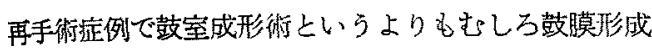
術を行つた. 鐙骨も残存せず術前と術後の変化の差はほ れど認められていない，術前。術後共に骨導衈力に変動 を認めず大体正常の值を示している.

No. 13 (図 13)

この姃例は術直後よりもむしろ途中で㯖力の変化をき たしている，骨導聴力に低下を認めず術中所見にて砧骨 もすで消失していて鐙骨も存在していないしかしな がら退院時高音域及び低音域も上戒の程度著しく連鑜な い場合飞拈ける聴力像としてはかなり良好な状態を示し ‘いる.

図 13

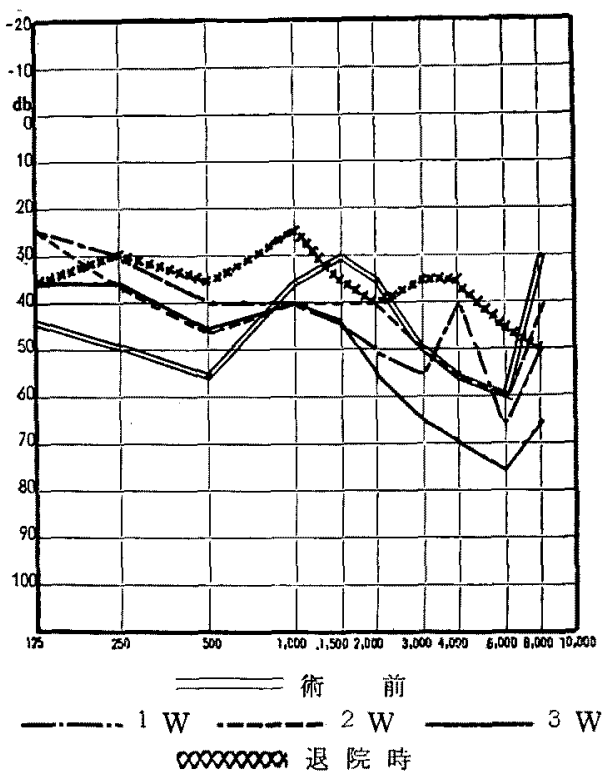

第3 節 小 括

辢室成形術を施行し大眼部より採取した薄い植皮片で 術創を覆つた後，1週每にガーゼタンボンの全交换を行 つて聴力検查を施行し㯖力の推移をを見た。

街後! 週目は全应例に批いて気導聴力の低下をきたし 術創の乾橾之共炕聴力は回復する，低音域よりも高音域 の回復はやや扰くれ，新生膜の形成される時期と密接な 関保があるらに思はれる、しかし症例中には術創が乾 蜗してもな活高音の回復をみないるのもある。

術㣪 1 週目の聴力の低下は主に滲出液の貯溜が原因と 考えられ，又新生膜の性質もこれの原因となつていると 考流れる。
大体聴力は 4 週後に術前又はそれ以上のレベルに゙で 回復し得る。

\section{第 III 章 退院時聴力之遠隔成精について}

第 1 節 研究対象及び研究方法

昭和 29 年上り昭和 31 年までに名大耳究咽煀科数室て 鼓室成形術を施行し，更に 1 年後に雨恰査した 148 耳と 昭和 32 年から昭和 33 年要でに手術を施行した 240 耳で あり，前者の 148 耳は 1 年後の聴力について，後者は退 院時聴力の值である、研究方法は第 1 編と全く同様であ る。

第 2 節 手術型の分類之頻度

前章と同様に耳小骨に重点を和き分類した，即ら種々 の操作の結果残存せしめた耳小骨の存在を中心にした。 その種類と頻度は第"10 表に示す

\section{表 $\quad 10$}

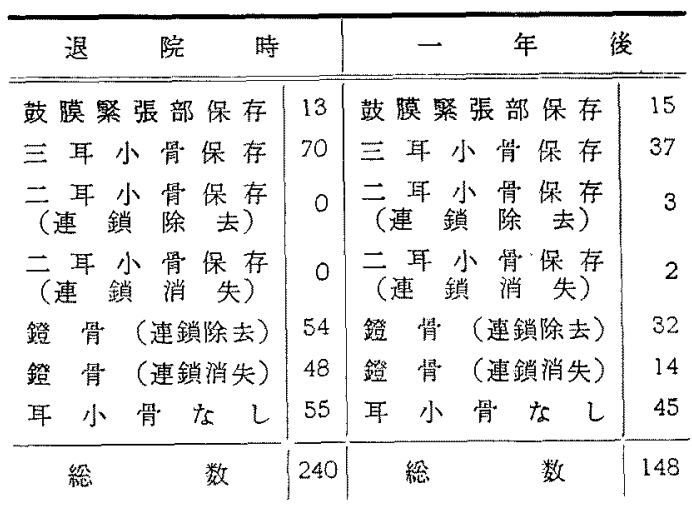

第3 䈱 成 績

i) 退院時聴力について

豉室成形術を施行した 240 耳で，その退院時聴力を各 周波数について術前㯖力と比校し，上昇。不变，低下の 各群に分ち，しかも手術型に分つて夫々の周波数の百分 率を示したのが夫々第 $14 ， 15 ， 16$ 図である。

祭银部保存の子のは上年例少く低音之高音にかなりの 低下を認めている。これに反して 2000c/s は不变の比 率が特に高い、

耳小骨残存例は僅か儿低音に和いて上笔例が多く認め られるが，3000c/s 以上では他の症例群との差美余りな い.

鐙骨残存例は連鎖の操作によつて僅かの相違が認めら れる，連鎖を除志しない方の症例群がやや結果に批いて 勝るよらである。

耳小骨の全く存在しない症例群は $2000 \mathrm{c} / \mathrm{s}$ 以上で兽 
力の改善されたものが多い，しかるに又低下例も2000 c/s 以上に多い上うである.

图 14

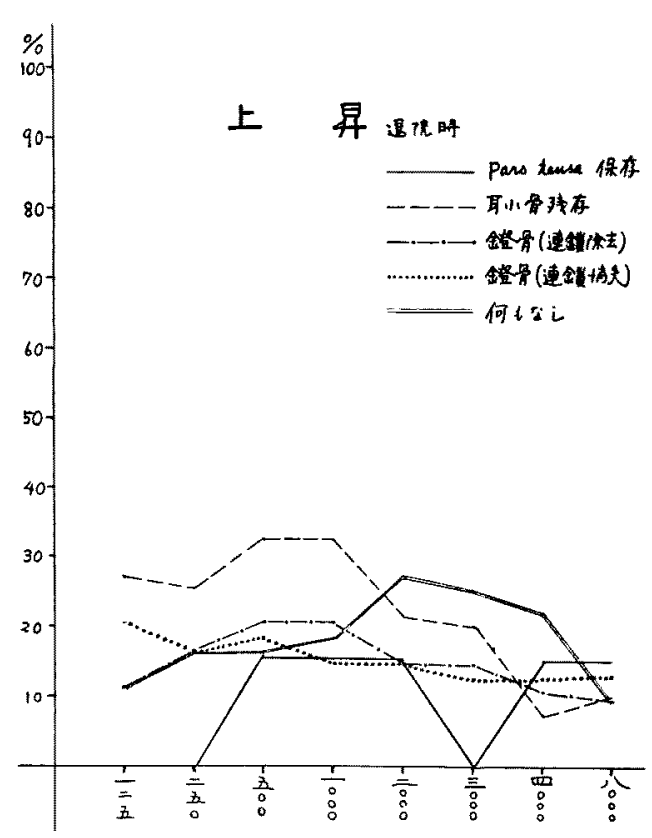

図 15

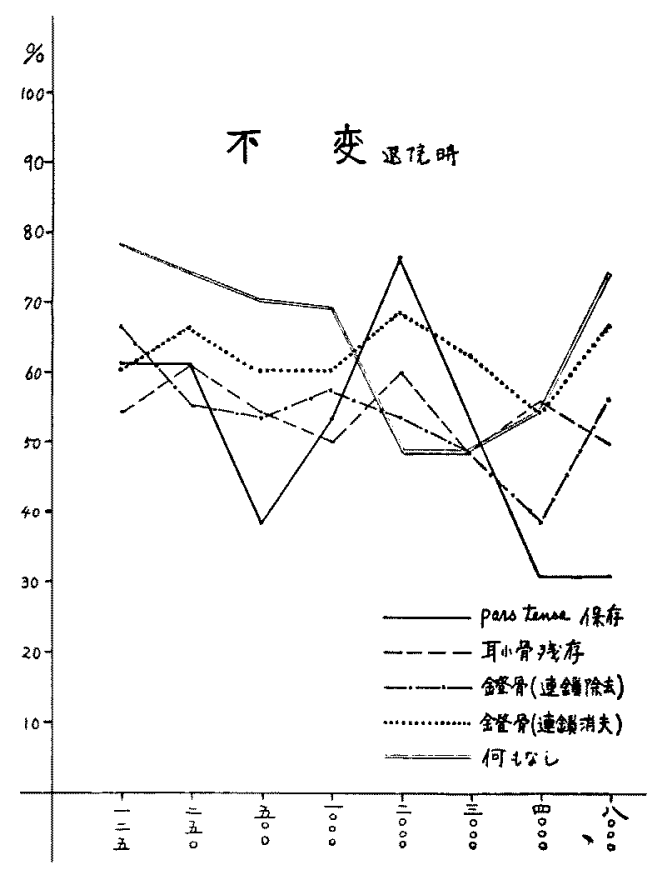

图 16

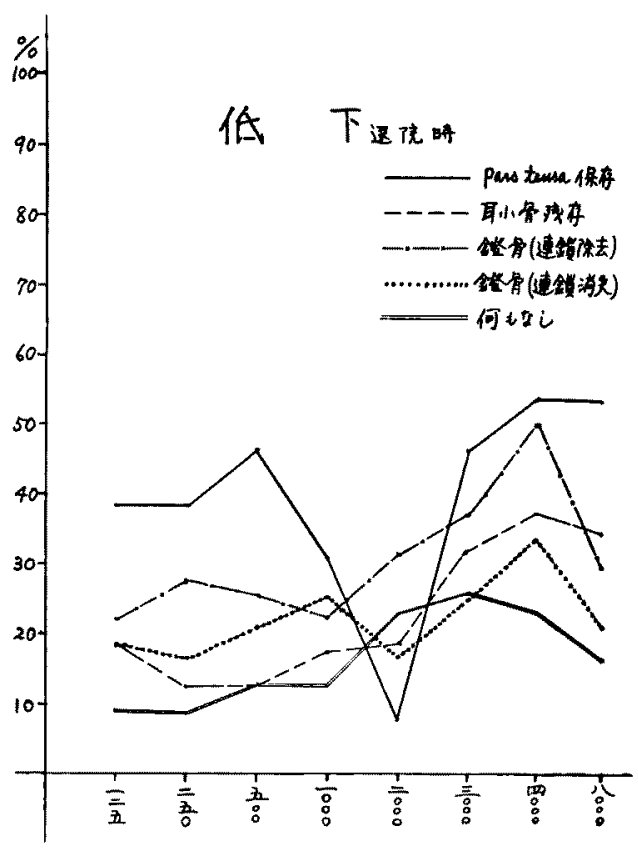

ii） 1 後年の聴力について

鼓室成形術を施行した 148 耳で， 1 年後の聴力を各周 波数厄ついて術前聴力と比較し, 上昇, 不变, 低下の各 群に分ち，しかも手術型に分つて夫々の周波数の百分率 を示したのが第 17，18，19図である.

熙張部保存例忙 $3000 \mathrm{c} / \mathrm{s}$ 孝除いて 低下例は非常比少 々, 不変例が非常に多い

耳小骨保存例は不変の值が割合にたかく，高音に秃い ては低下例多く伝音形態は理想的である筈であるがその 結果は余り良好ではない。

ここに注目すべきは連鎖消失の鐙骨残存例で上昇例が 非常に高い値を示しており，退院時と比較して大きな差 を示している。

耳小骨の存在しない例では低下の割合高く，高音へと その割合が増大して行く 上我例も他の症例群に比較し て非常に少い：これは退院時成績に执いても同しょうな 傾向を示している.

各手術型群と各周波数との間には特殊な因果関係を見 る事はできないが，両者の成績を比較すると連鎖除去後 の鐙骨残存例と連鎖消失の鐙骨残存例化かなりの差のあ る事が認められ，第 1 編第】章で述べたと同様に，でき る限り連鎖は保存すべきであるとの結論に達する.

いずれの例飞おいても三耳小骨を保存し，正常に近い 
国 $\quad 17$

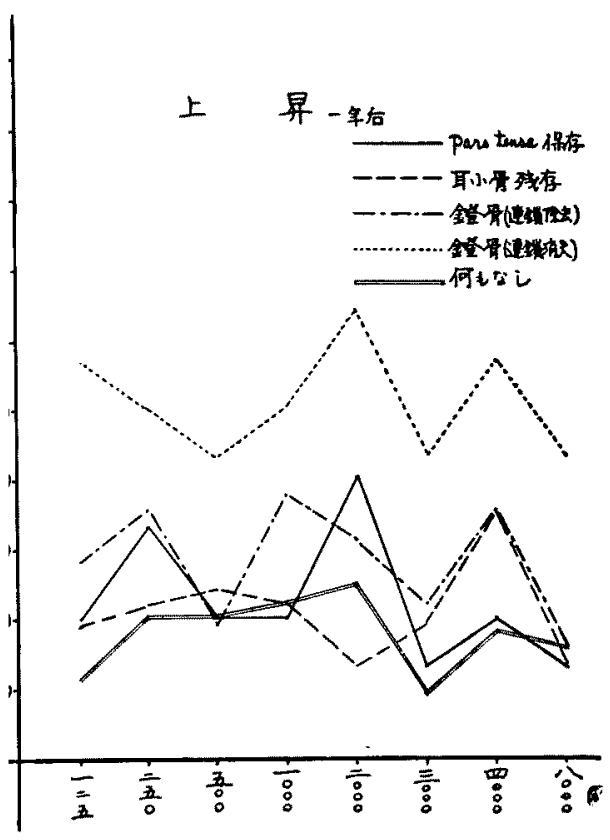

图 18

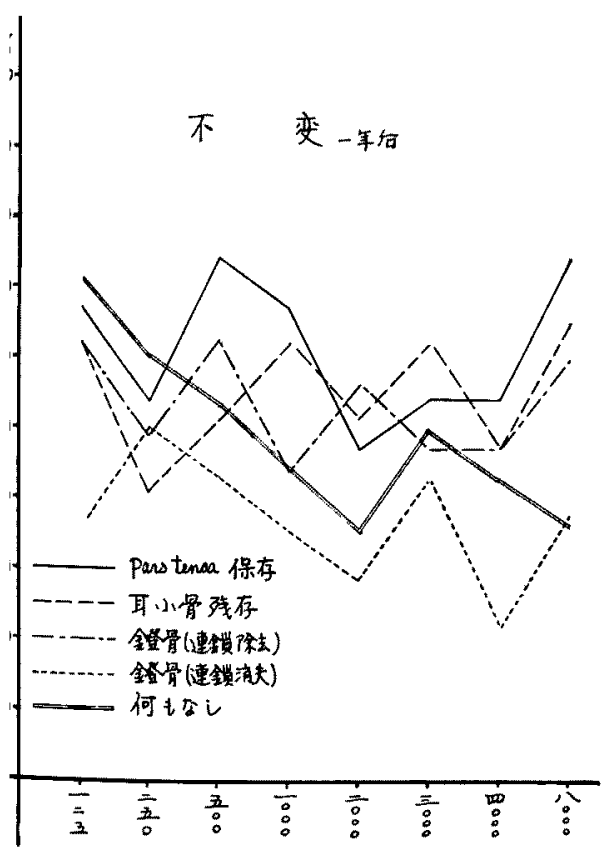

図 19

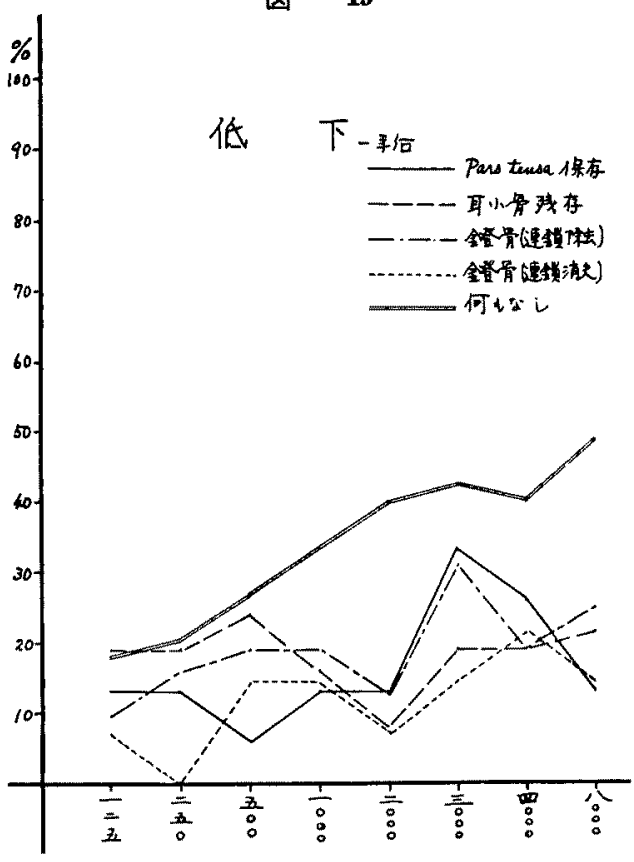

數室腔を作つたと考えられる耳小骨保存例がその割合か ら云うと余り好結果を出していない，鼓膜緊張部保存例 に扎てすらかなりの低下例を示している。

又低下例佂いて退院时と 1 年後の症例群を比較して みると明らかに退院時に扎いて，3000 c/s 以上の高音域 に低下例多く 1 年後はこれが非常に少くなつている. 但 しこの症例群について耳小骨の全く存在していない場合 は例外の結果を示している。

\section{第 4 節 小 括}

各手術操作が退院時聴力及び這隔成續㯖力にどの程度 の影響を与えているかをみた，便宜上定めた代表值を以 つて集計した上杽，不变，低下群の定例数からの判断で は，耳小骨保存例に大なる期待を持てず失望させられる よらに思点るが，細かく1例，1例に観察すれば上年の 傾向大であり，連鎖除去例上りも連鎖消失例即ら必要以 上に連鎖を破壊しなかつた例に回復傾向が強い.

又 $3000 \mathrm{c} / \mathrm{s}$ 以上の高音域に和ける 回復の悪さも退院 時之造滆成續ではかなりの差を有し，第 II 章で述べた如 く変化のある事を証明している，即ち鼓室成形術は鼓室 腔をできる限り正常へと近づけるよう努力する事が術後 の聴力回復を良好ならしめる。しかし高音域を上界させ る事にはやや困難が伴5，低，中音域の低下例は平㘬䄪 20〜30\%であるが高音域の低下例はこれよりややうわま 
わつている，そして連鎖についての手術操作の差買が 1 年後の逻隔成績に大きく現はれている点が重要と芳え b.

\section{第IV 章 術後の權得聴カについて}

第 1 節 研究対象, 研究方法及び手術型の分類 研究対象は昭和 29 年より昭和 33 年に至るまでに名 大耳鼻咽唉科教室で鼓室成形術を施行した 148 耳であ り，研究方法及び手術型の分類は第】章と全く同様であ る.

\section{第 2 節 成 績}

i）症例の分類及びその頻度

$250 \mathrm{c} / \mathrm{s}$ より $2000 \mathrm{c} / \mathrm{s}$ 亿至るまでの周波数の聴力損失 を目標に分類した， $3000 \mathrm{c} / \mathrm{s}$ 以上の高音はこの章では余 り考慮せず，2000c/s までの周波数について各症例が術 後どの程度のレベルに聴力閾值を維持しているかを問題 にしている．聴力曲線の特徽によつて分類すると下記の 如くになる.

1. 鼓膜緊張部保存（三耳小骨保存）

第1型 $2000 \mathrm{c} / \mathrm{s}$ までの閶做がほぼ正常

第 2 型 $2000 \mathrm{c} / \mathrm{s}$ までの䦔值が平均 $30 \mathrm{db}$ 損失

\section{2. 棺骨鐙骨接合}

第 1 型 $2000 \mathrm{c} / \mathrm{s}$ までの閾值が 15 20db に中心あ り

第 2 型 $2000 \mathrm{c} / \mathrm{s}$ までの閶值が 35〜40db に中心あ $\eta$

3. 新豉膜形成（三耳小骨保存）

第 1 型 $2000 \mathrm{c} / \mathrm{s}$ までの閔值が $35 \mathrm{db}$ 以下のもの (35db としたのはこの附近淿中心を持っ 聴力像が多かつたためである)

\section{a . 德力損失の軽度の群 \\ b ．聴力損失やや高度の群}

第 2 型 $2000 \mathrm{c} / \mathrm{s}$ までの間值が $35 \sim 55 \mathrm{db}$ のもの a. 損失平均が 35 40db の群

b. 損失平均が $45 \sim 50 \mathrm{db}$ の群

c. $2000 \mathrm{c} / \mathrm{s}$ にピークを有する群

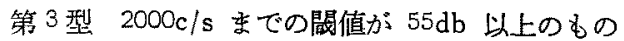

4. 鐙骨残存

a . 損失平均か： 20 30db に中心あり

b. 損失平均か $40 \mathrm{db}$ K中心あり

c. 損失平均が $50 \mathrm{db}$ K中心あり

$\mathrm{d} \therefore$ 損失平均

: 5:: 耳小骨存在せず

a 、損失平均が $40 \sim 50 \mathrm{db}$ に中心方り

\section{表 11}

1. 跂膜緊張部保存

$\begin{array}{ll}\text { 第 一 型 } & 2 \\ \text { 第 二 型 } & 6\end{array}$

2. 棺骨鐙骨揬合

$\begin{array}{ll}\text { 第 } \text { 型 } & 2 \\ \text { 第 }=\text { 型 } & 4\end{array}$

3. 新鼓膜形成

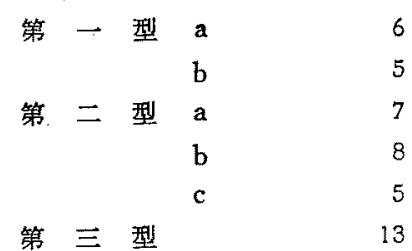

4. 鐙 骨 残 存

5. 耳小骨就と

$\begin{array}{rr}\mathrm{a} & 6 \\ \mathrm{~b} & 26 \\ \mathrm{c} & 16 \\ \mathrm{~d} & 18\end{array}$

a 11

b 19

b. 損失平均が $60 \mathrm{db}$ 以上

これらの分類によつて症例数は表11 亿示される. 即 ๖ $35 \sim 55 \mathrm{db}$ 損失の 新鼓膜形成症例と 30 50db 損失 の鐙骨残存症例，60db 以上損失の鐙骨残存例，60db 以上損失の耳小骨のない症例が多い。

ii) 聴力像仙ついて

これら症例群の audiogram の重積像を図唀したの が第20図より第 29 図である.

鼓膜祭張部保存の術後聴力像は $2000 \mathrm{c} / \mathrm{s}$ までに関し ては間值が正常に近似するものと $30 \mathrm{db}$ 前後の水平像 を呈する群に分け得る。この群に打ける变化は乳様洞及 び上鼓室が開放され，橋部は保存されず，正常な耳と巽 なる点は外耳道が後方に掋大している事と，上鼓室の開 放による影響である。故にこの症例群は理論上正常閜値 に留るべきである、しかし事実は高音低下と $30 \mathrm{db}$ 前後 の損失を示している.

桘骨之鐙骨保存の術後聴力像は第 21 困に示してある。 この症例群は鼓膜緊張部を保存して病的所見呈する砧 骨を除去し，桘骨之鐙骨頭を接合したもので，この群も 二つに分け，会話領域周波数損失が 15 20dbを中心 としたものと，35〜40db を中心としたものとである.

新豉膜形成群の術後聴力像は図 22 と図 23 に示す. こ 
I型
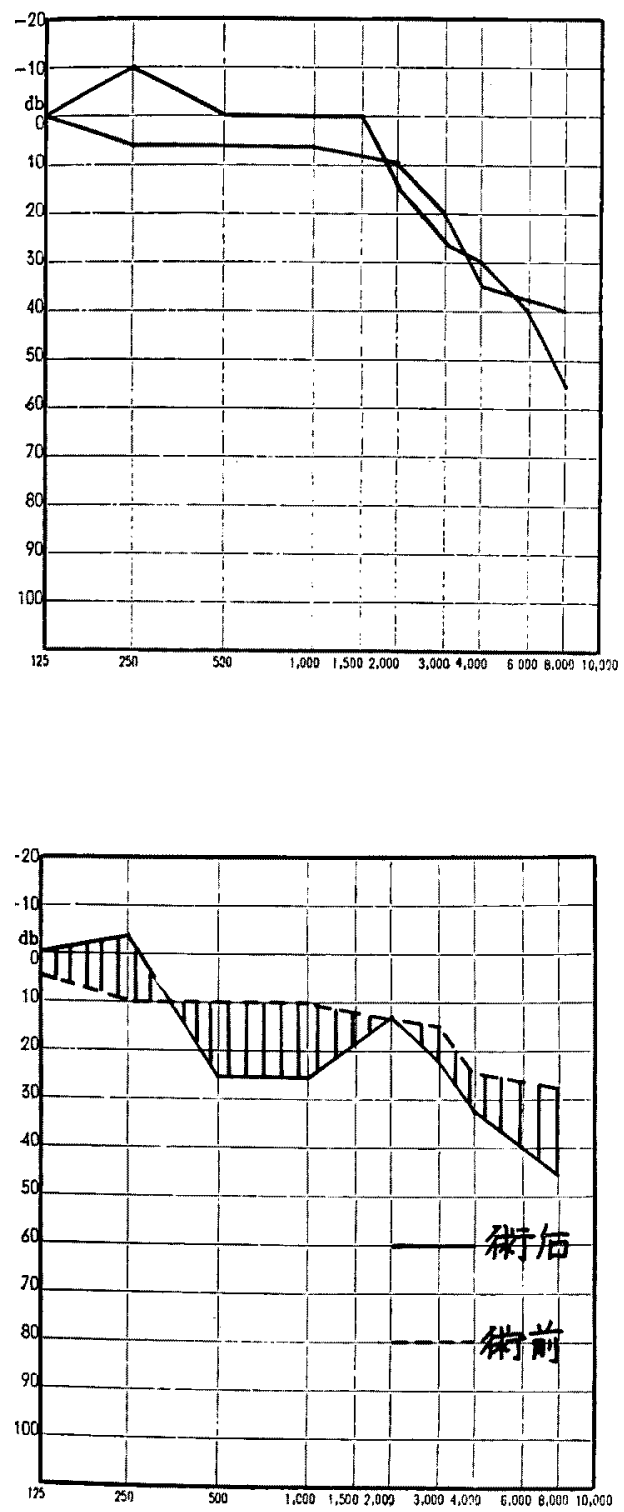

I型
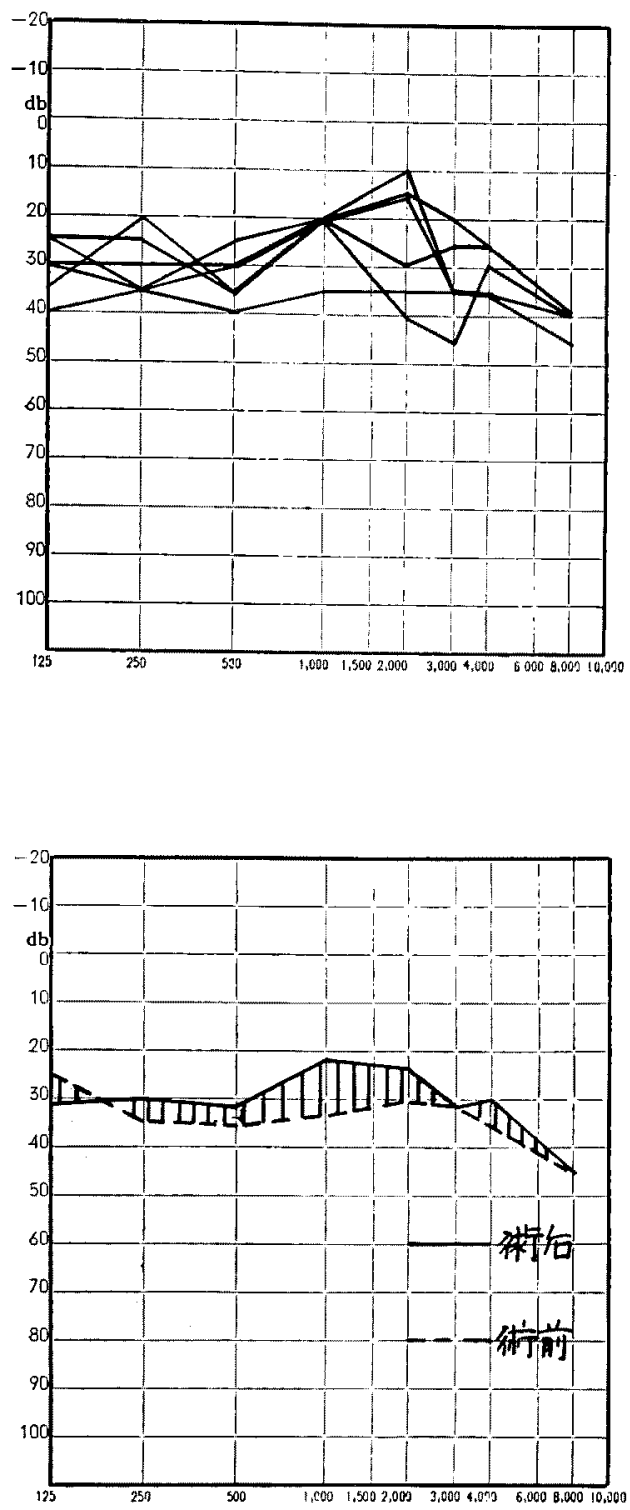
图 21 槌骨 - 鐙骨接合

I 型
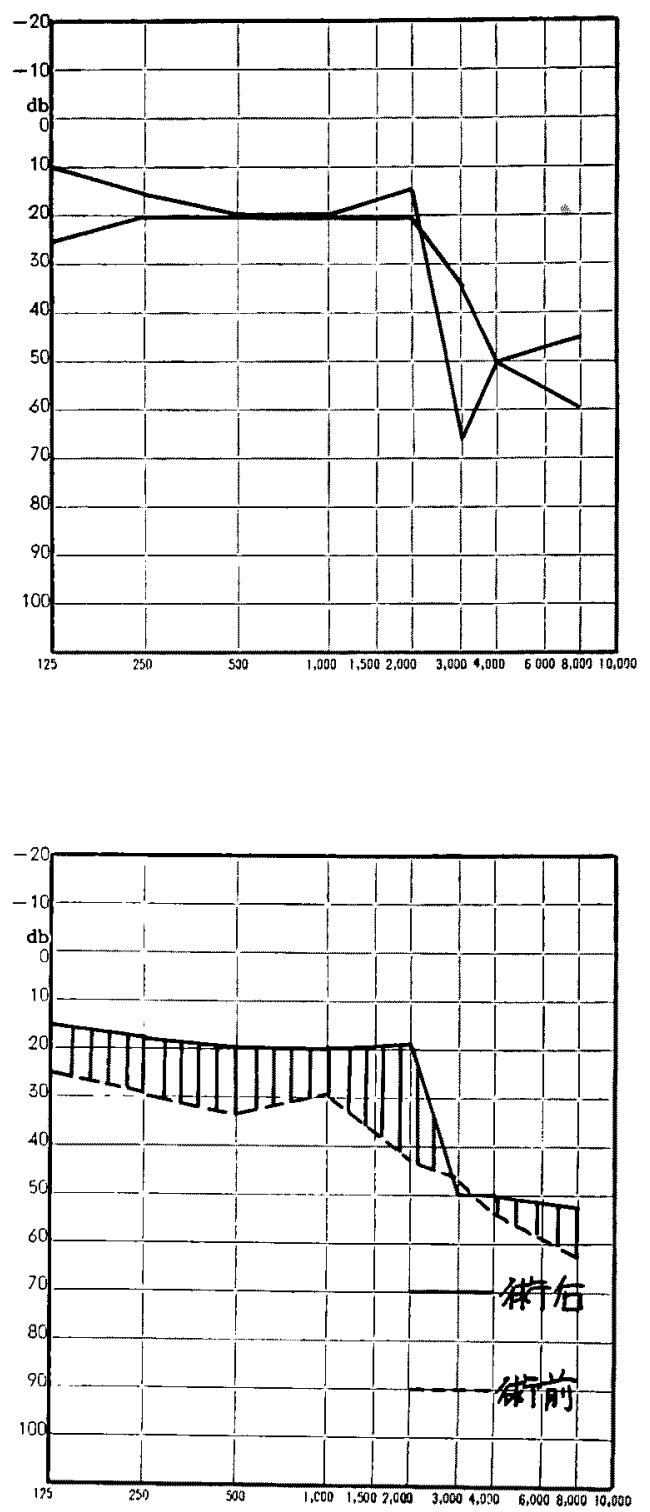

1 型
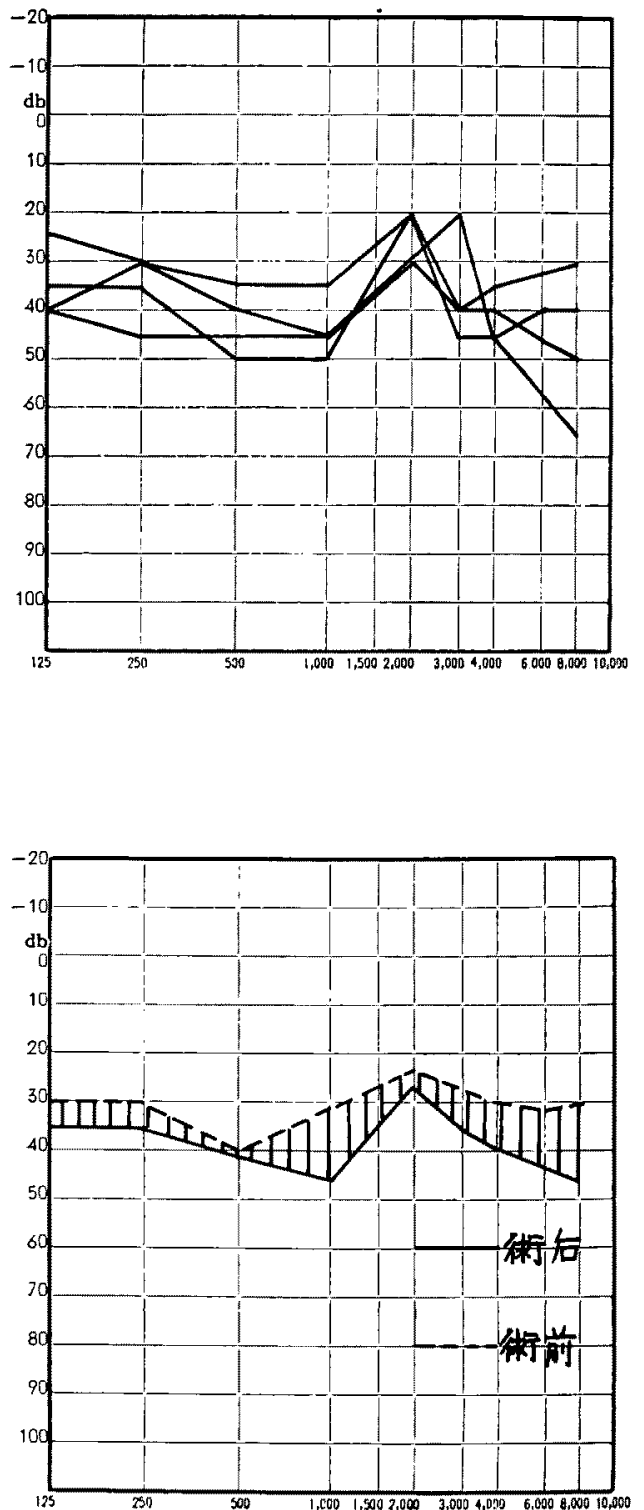


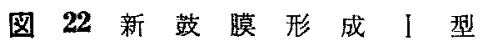
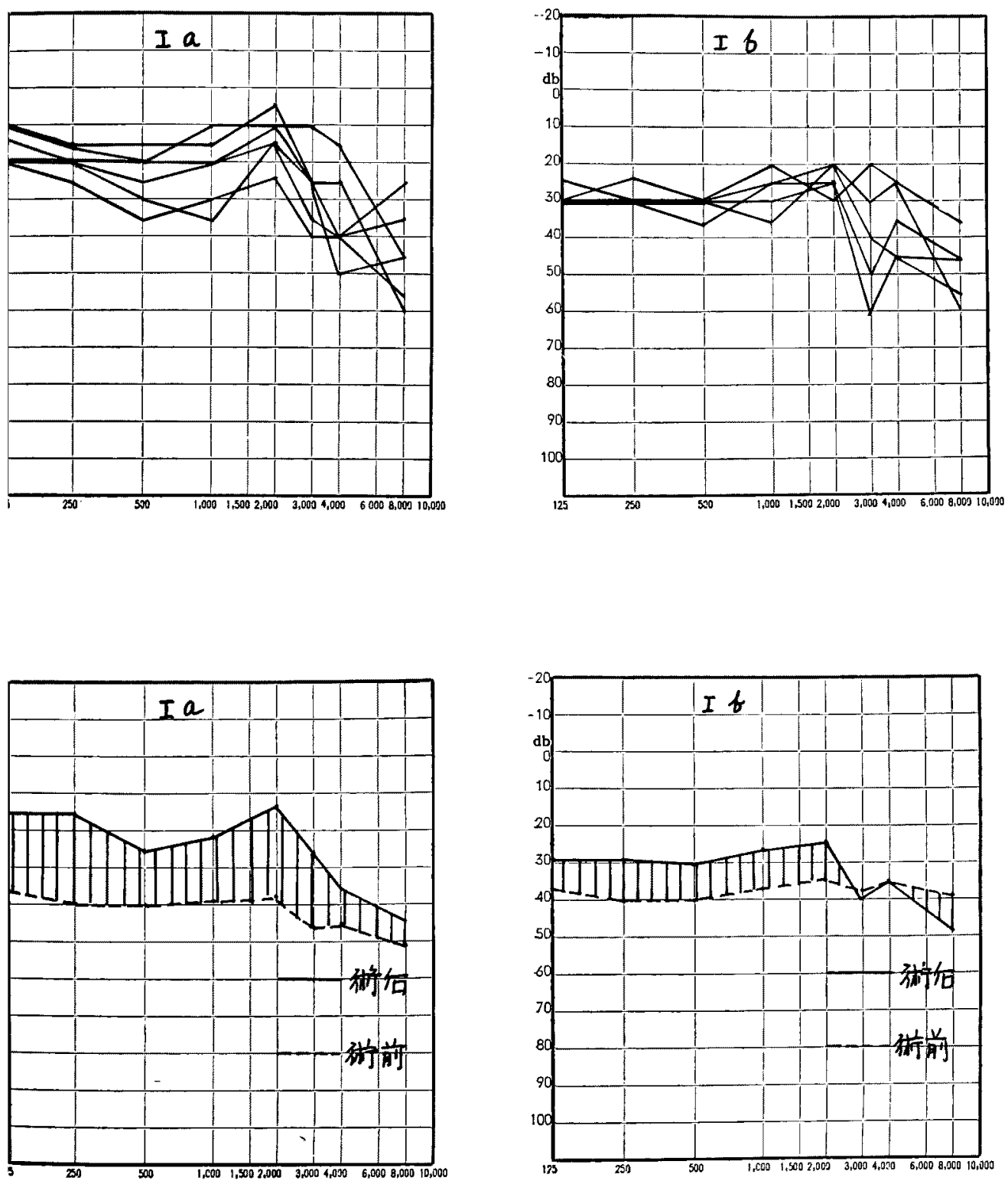
图 23 新鼓膜形成】型
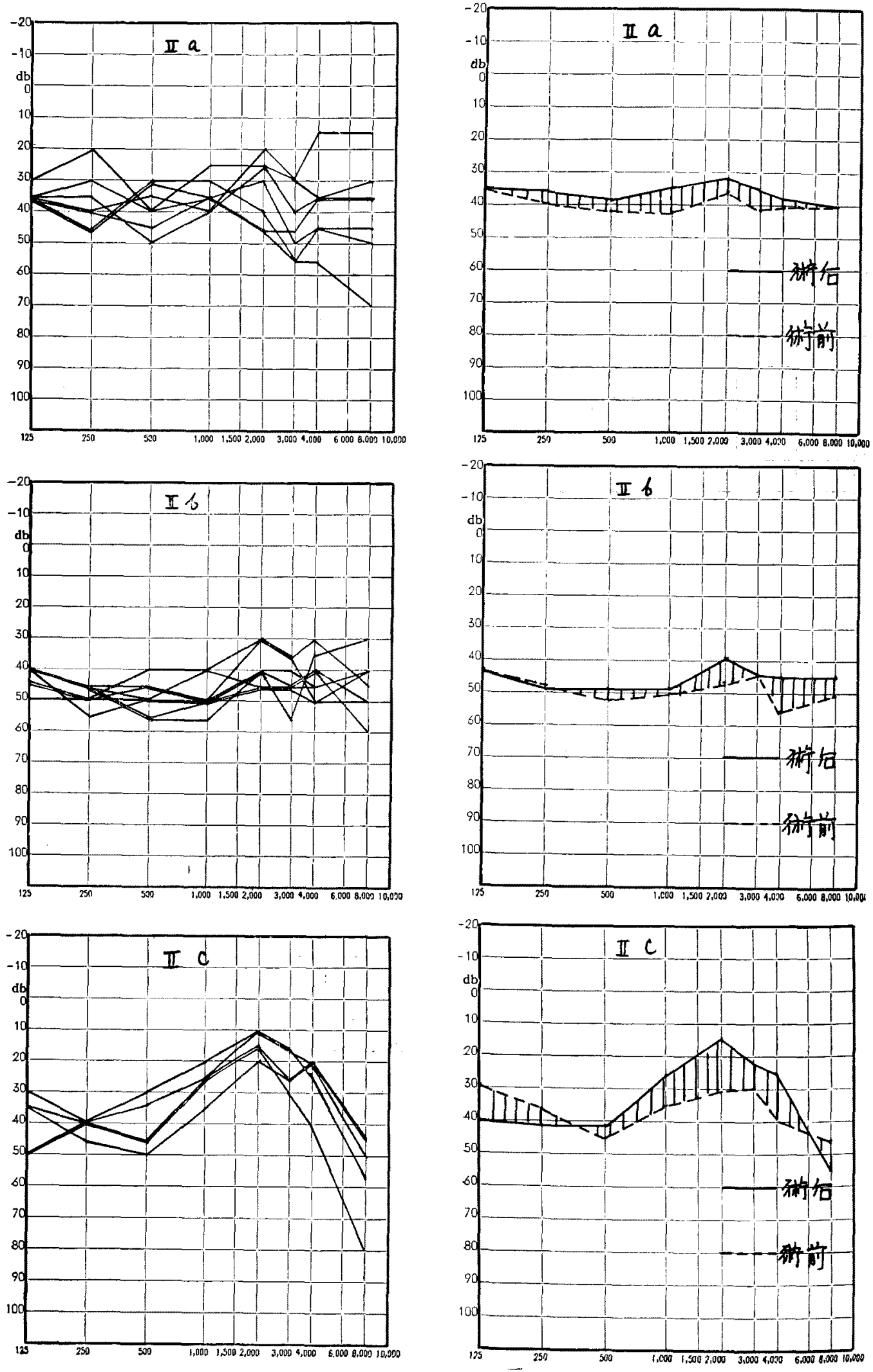
图 24 鐙骨残存
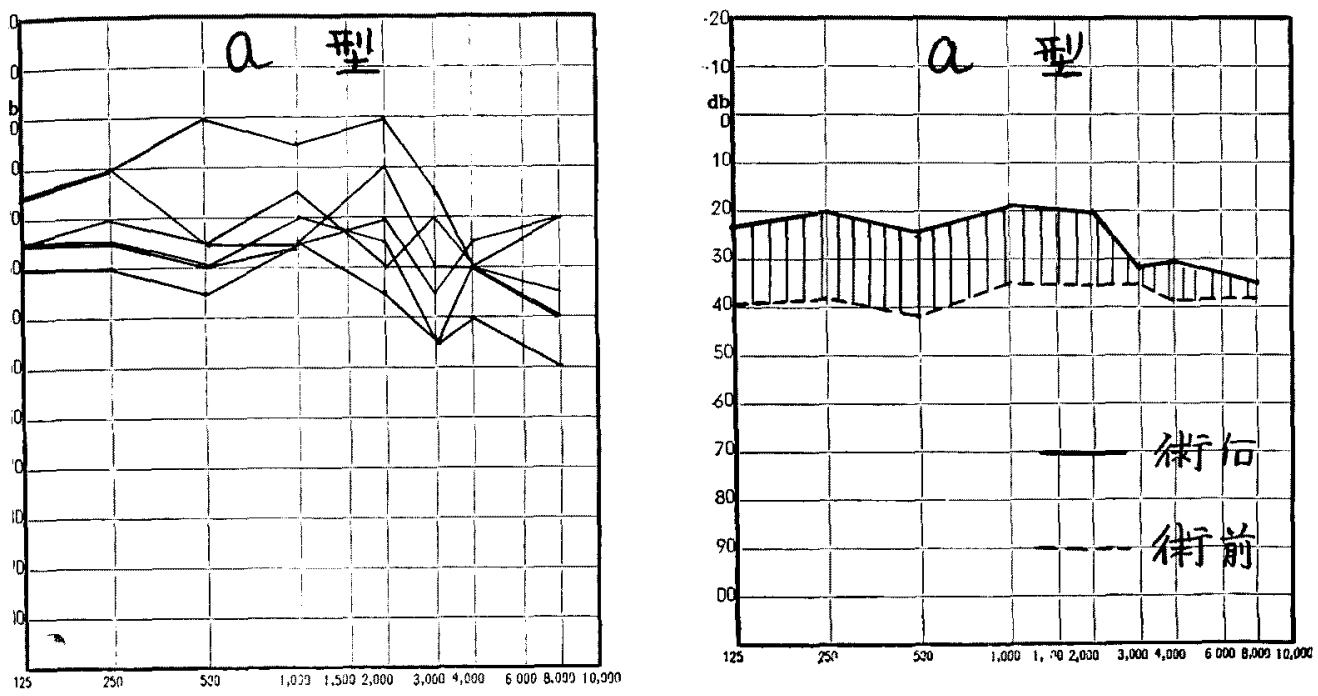

图 25 鐙 骨 残 存
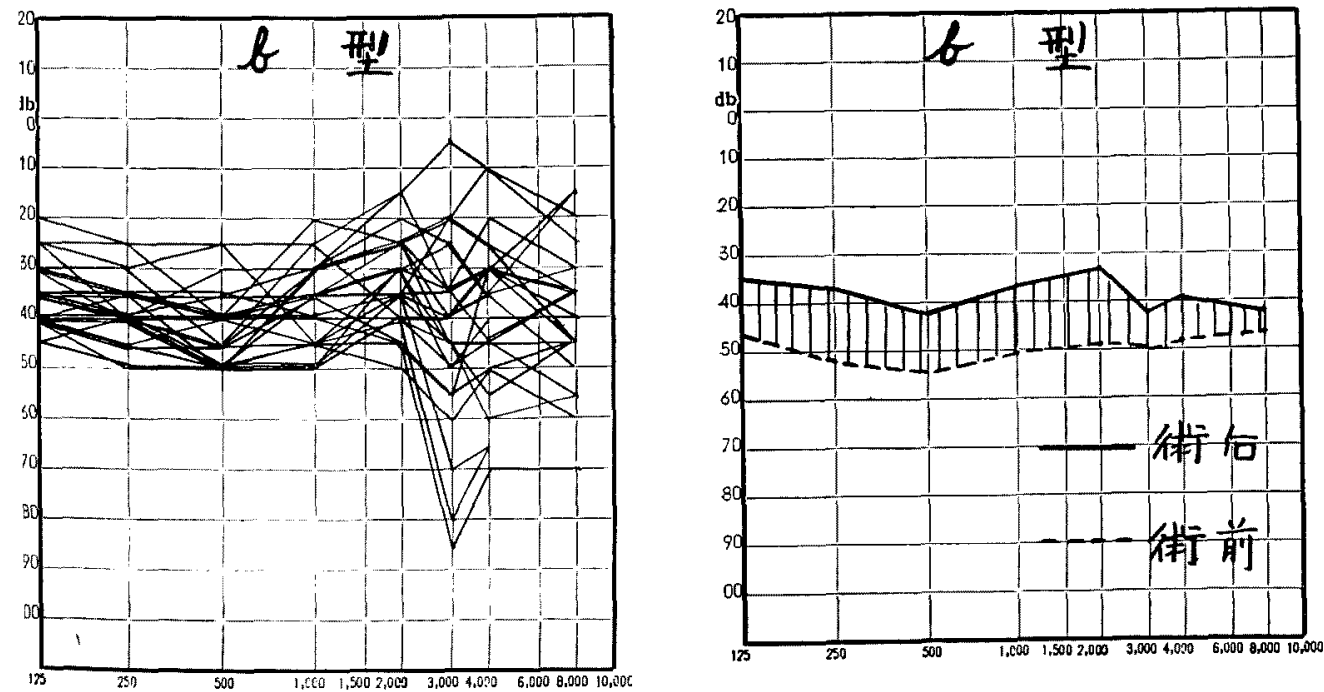
図 26 鐙 骨 残 存
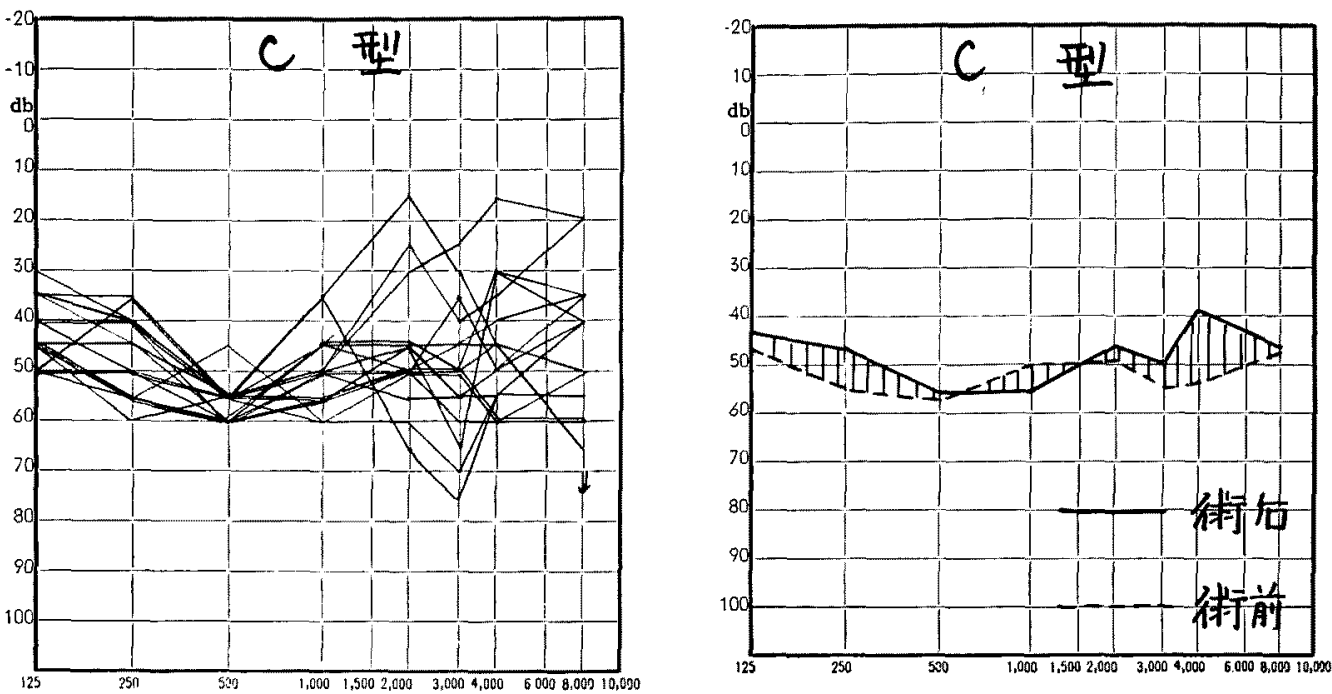

图 27 鐙 贯 残 存
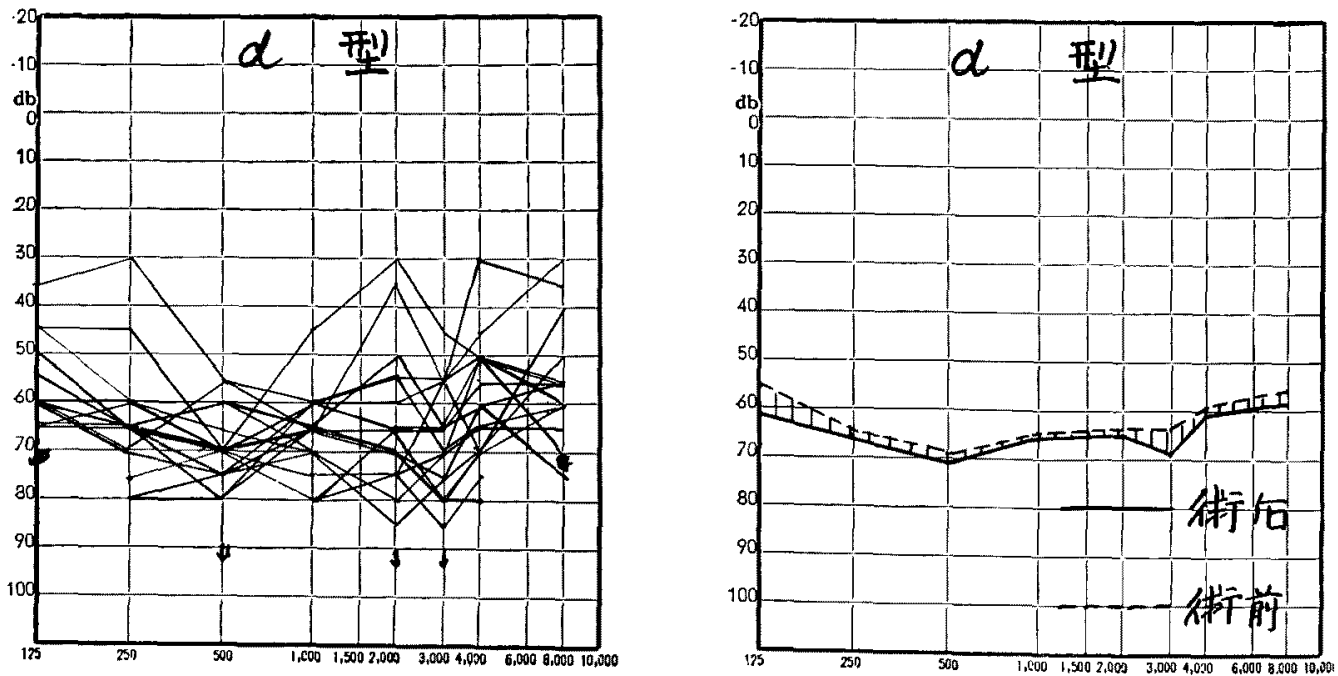


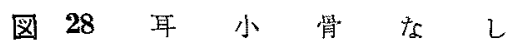
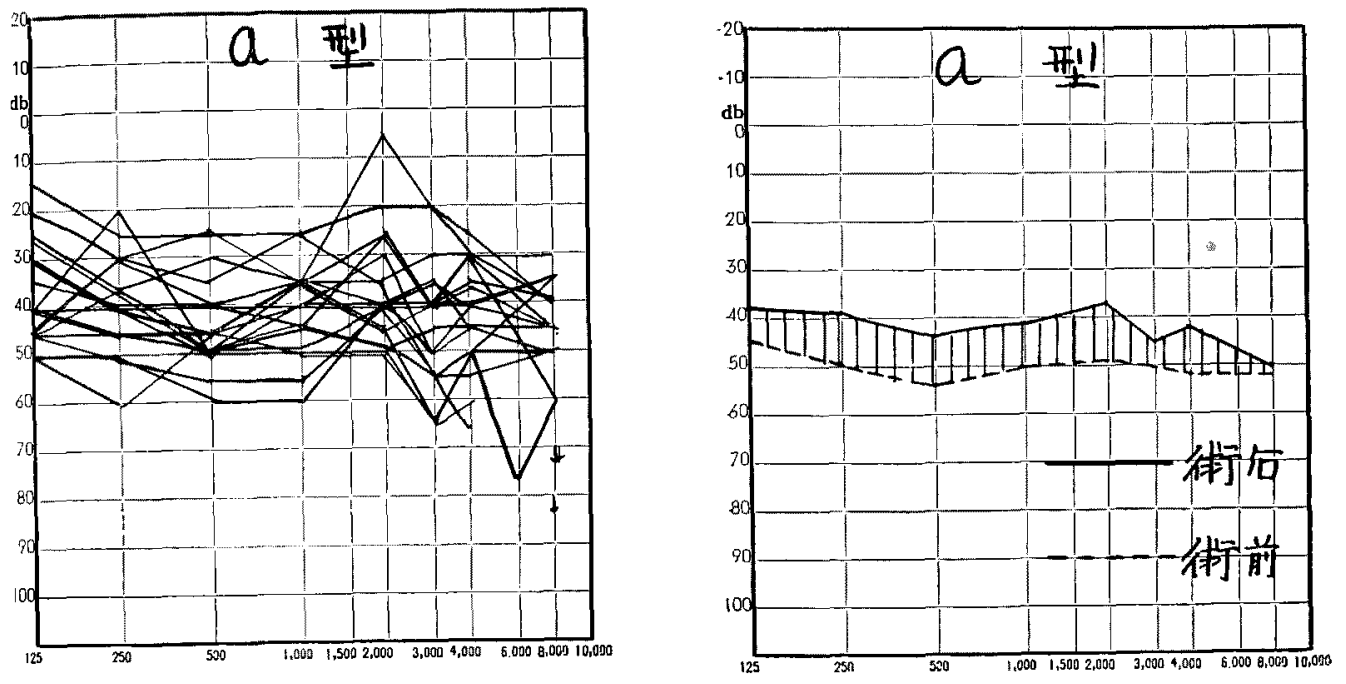

图 29 耳小骨な
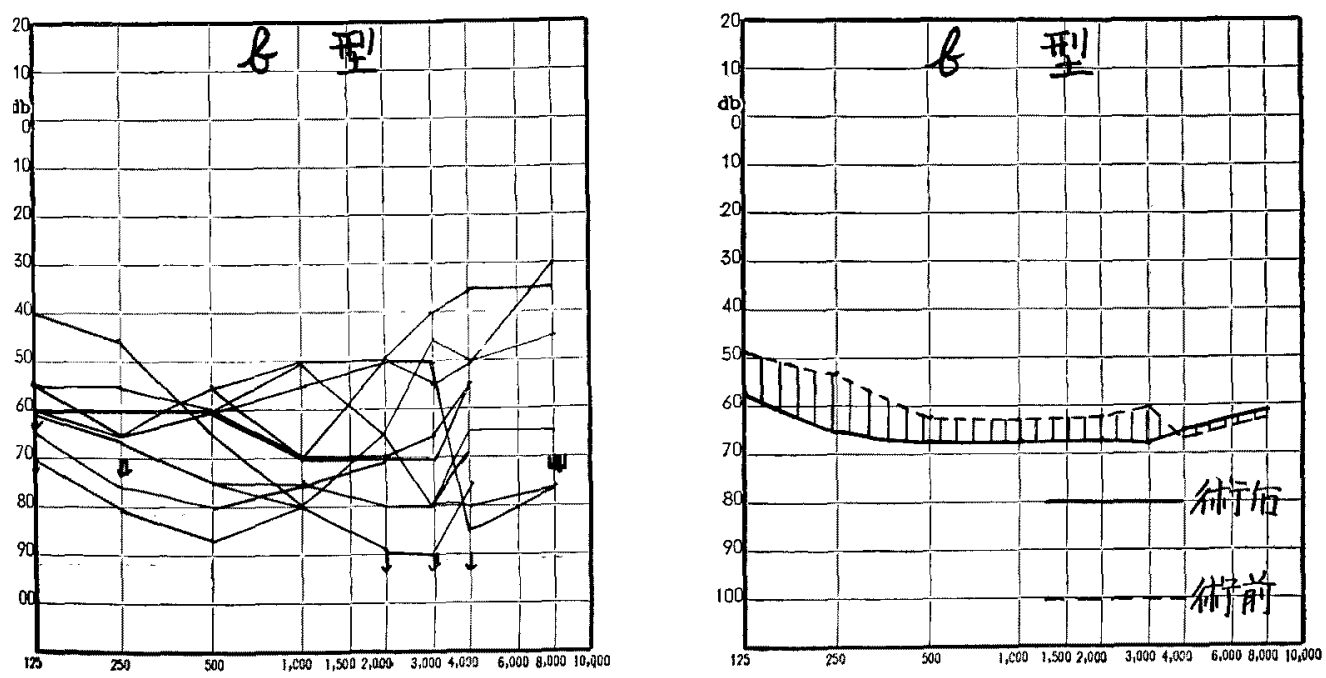
んは三耳小骨を牫存させ新敖膜を作製した症例群で術後 德力像は非常に変化に富えでいる。この中で問題となる つは $2000 \mathrm{c} / \mathrm{s}$ にピークを持つ1群である。

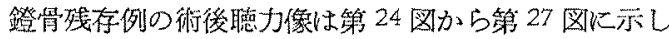
てある，連鎖が完全に残つているものに比較して聴力間 值が 30db 以下のものは少く，20〜30db を中心とする もの上りもさしる大体 $40 \mathrm{db}$ を心とする德力像が多 、第27図火示寸ものは骨望聴力低下をきたしている 证例多く統一ある聴力像を作り得ない。

耳小骨のない症例の術後聴力像は第 28 図と第 29 図に テしてある．この場合も新鼓膜形成群之同㥞に術後聴力 像は変化火富及，㙂力損失が 40 50db K中心ありと考 えられる定例が多い

以上の結果加鼓膜祭張部保存型の】型群と耳小胃残 存のりb 群とははぼ同型の聴力像老有し，又耳小骨保 存の I a 群と鐙骨保存の b 㤠群の聴力像が近似してい る.この術後の聴力損失の值からのみ考文，これら同程 度の聴力損失を示するのは同一の伝音形態を営んでいる

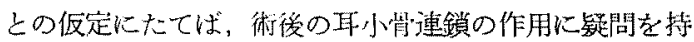
たざるを得ない，

图 30 良好

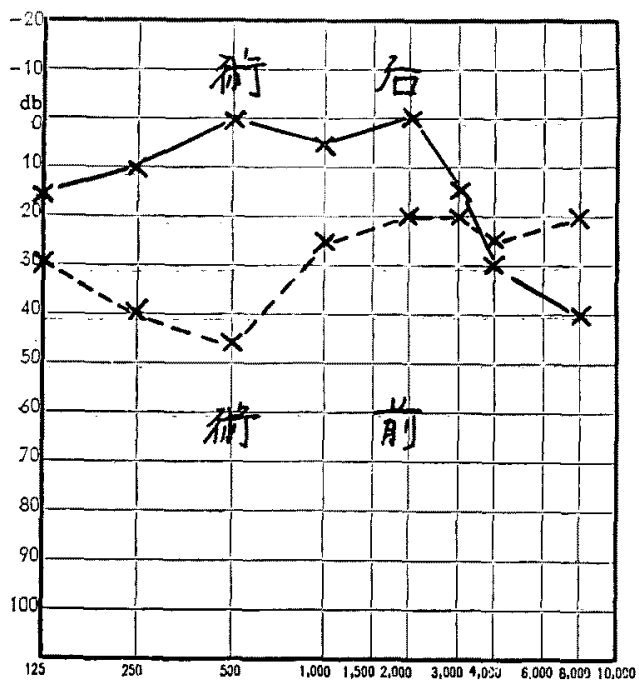

第3 節 小括

各手術型が術後どの程度の聴力損失でとどまつている かを観察した。

動物を使用して C.M. を老測定する事によつて得られた

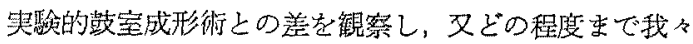
は期待し得るかる知るために行つた。
名図の聴力重積像とは別に示してあるものは各群の術

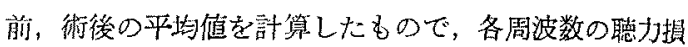
失を $\mathrm{db}$ ですし，それについて術前と術後の平㚬値を此 较して及たものである。これによると会話領域における

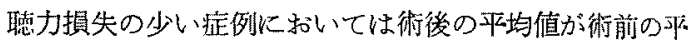
均值に比して著明な上具をきたしているに反し，術後埴 力閶値の大なるものは術前と比較して低下している事が 判明する. 更に鐙骨残存の c 及び d, 又耳小骨の存在し ない群においては、術前、術後の平均健の差は僅か炕な り遂にその差は逆になつてゆく、この点から考えると術 前の聴力が非常に良好なるのは瑟化する事少く，これに 民して術前缌力 $60 \mathrm{db}$ 以上のbのは術後聴力の好結果を 期待し得ない.

しかし㬰際には陲物実駼の值からは全く想鮛され得な い上うな聴力に達した症例もある。これら症例群のうち 最も代表的な2 例を図30に示した。 この二つの在例は 鐙骨残存例亡耳”䧎のない症例で，いずれも術中所見， 術後の経過にも特記すべき点はなく，1例は $10 \mathrm{db}$ 前後 屯で，他の 1 例は $25 \mathrm{db}$ 附近むで回復している。

なる症例

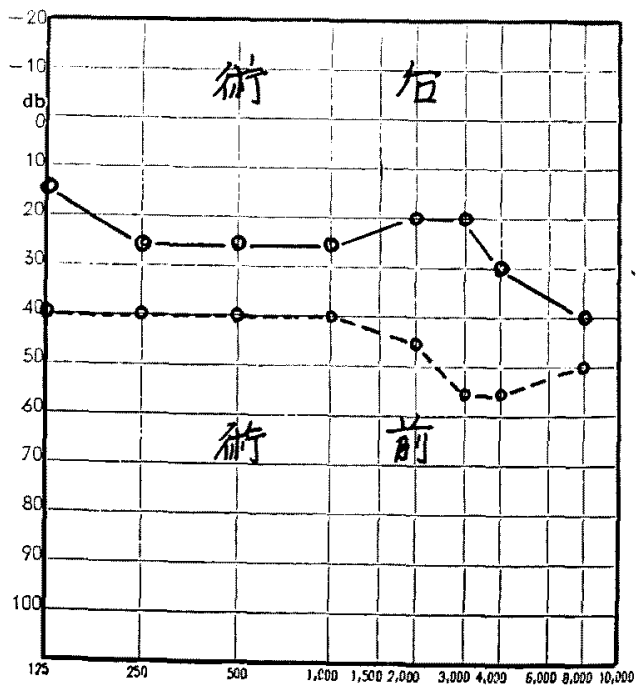

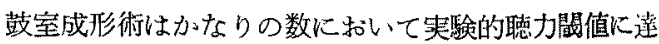

し，実駼值と近似する。

又近似しない群では耳小梋保存例之蹬骨保存例に同じ

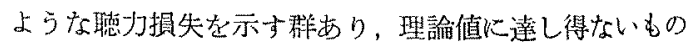

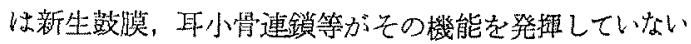
牙が示された。 
術前㯖力の良好なるもの程術後㯖力は実用価值を有す るもの多く，回復も良好である。これに反して術前悖力 $60 \mathrm{db}$ 以上の閐倡のるのは術後の回復が甚だ困難である ことが推論される。

\section{第 V章 総括並びに考按}

E.G. Wever は中耳伝音障碍を 1) 鼓膜穿孔又は欠 損，2）耳小骨連鎖の離断，3）耳小骨連鎖の可動制限， a）液体又は類腋体に上る可動制限，b）単純な機械的 可動制限，c）耳硬化症によるる可動制限に分類してい る. 我々が鼓室成形術を施行している慢性中耳资の症例 では䧽々の病変の程度に上つてこれらの条件圭伴つて特 りこれら伝音系の障碍を修復寸るのが鼓窒成形術の目 的である.我々の行っている鼓室成形術は植皮片を大垠 内側部より採取し，外耳道皮弁文は耳後部よりの皮弁を 使用していない，採取した植皮片は比較的らすくこれを 耳内淔皮する事によつて，その下に新しい上皮形成を 此こさせることを目的としている，よつて新しい膜は辢 皮片の下面にそつて生ずる.我々は術中植皮片で術創を 覆う場合，その拈き方，支持面等化非常な注意を払つて いる.これはあくまです植皮片の下にできる新しい上皮 怯伝亲の一つの膜として作用を有するとの仮定の上に たつている.

前編にも述へたように，新生膜が膜としての性質を有 するか否がつては，Wullstein は諭交の中で淢問 を呈したままその解答を与えてはいない，著者はこの章 に沏いては耳小伟に重点を扰き，新生膜は脱としての作 用をなすとの仮定の上になつて観察し，その data を宇 蹒值と比較してみたのである.

Wullstein の理論仙よれば豉室䐋が正常と考えられ

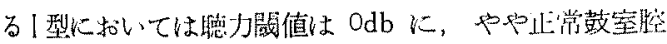
と恙翼ある』型及び鐙骨のみ存在する四型は所謂 lever action の損失により $2.5 \mathrm{db}$ に，鐙鮹も存在しないい $N$ 型 は，20〜30db の損失を示すとしている。本編し批いて

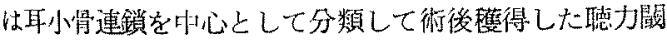
値については $2000 \mathrm{c} / \mathrm{s}$ までの楇波数を主体に検討した。 即古

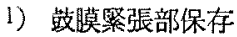

2）鼓暯，桘骨，镫骨保存

3) 新鼓膜形成

4) 鐙骨残存

5) 耳小骨存在せず 以上ら群である。

これら症例群を理論的に钼察するため, 幾多の研究者 達恃種々の方法を試みてその条件を或駼的炕作らんとし

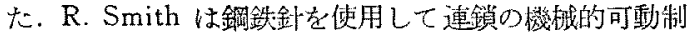

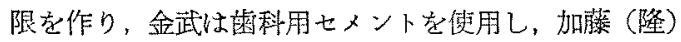

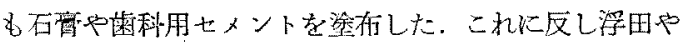

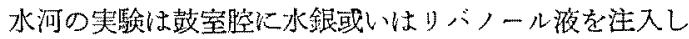
て可動制限を括こさせている。

これより 以前に Wever 及び Lawrence が正常及び

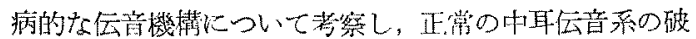
塄に上り平均值約 $28 \mathrm{db}$ の損失赵生し喊膜の多化は一般 に10〜20db の損失があると羪告した，私の分類する1) の鼓膜緊張部保存例は上鼓室及び固有鼓膜室の病変少い がために残し得たのであり，理諭的には乳様洞閒放し故 膜驰緩部までを植皮片で覆つた牙となり，これで回復良 好な群は平均 $10 \mathrm{db}$ の損失を示し，户や不良の群は 25〜 $30 \mathrm{db}$ を示している。 又 2) の鼓䑏・桘骨・蹬骨残存例

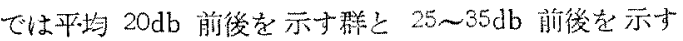

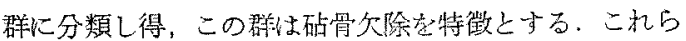

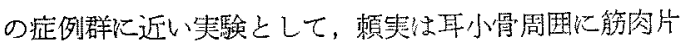
を插入して，全周波数領域に和いて約 $20 \mathrm{db}$ 内外の水平

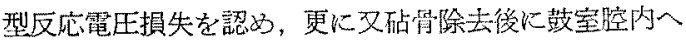
笳肉小片を插入した時は低音域で最高 $30 \sim 45.5 \mathrm{db}$ ，高音 域に移動するに従い減少する傾向を示したと報告してい る，更に関節帅带のみの離断で $10 \mathrm{db}$ ，関節の断端を セハントに上り接台した場合壮 $11 \mathrm{db}$ であると云う、 又

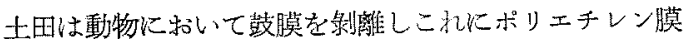
をはり，平里にはつた場合と円錐形にはつた場合でその 回復に非常な差があり前都は $26 \mathrm{db}$ ，後者は $44 \mathrm{db}$ であ るとしている.

これらの值から比軟してみると私の拝例群はすべてこ

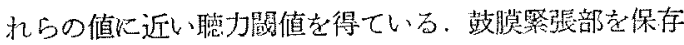

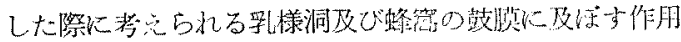
について，恩地はラグランジ二の暹助方程式をいれて中

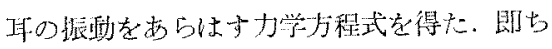

$$
\begin{aligned}
& Z_{\text {THMA }}=R_{T}+\frac{S^{2} \cos \beta}{\omega^{2}\left|Z_{A}\right|}+\frac{S_{2}{ }^{2} \cos \theta}{\omega^{2}\left|Z_{H}\right|} \\
& \quad+\mathrm{j}\left(\omega M_{T}-\frac{S T M}{\omega}-\frac{S^{2} M \sin \beta}{\omega^{2}\left|Z_{A}\right|}-\frac{S_{2}{ }^{2} \sin \theta}{\omega^{2}\left\lceil Z_{H} \mid\right.}\right)
\end{aligned}
$$

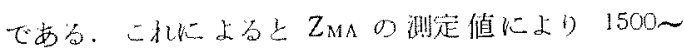
$3500 \mathrm{c} / \mathrm{s}$ の間で主として抵抗起增加させ，去のために散 膜の振動は減少するが $10 \mathrm{db}$ にとど李る上述べている。

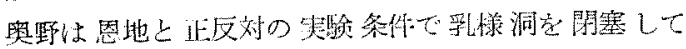

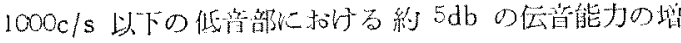

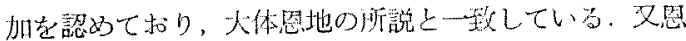

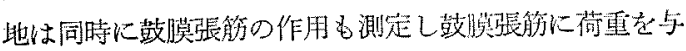


えると連鎖の $1500 \mathrm{c} / \mathrm{s}$ と $3500 \sim 4000 \mathrm{c} / \mathrm{s}$ にある2個の 其唯ピークか゚商音域に等れると云う。しかしこれによる 氐音域での連鎖の振幅の減少忧 $2 \mathrm{db}$ 程度であり，防音 乍用又は音量調穊作用は㱠んどないと考えられると絈諭 している。

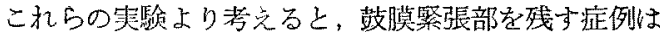

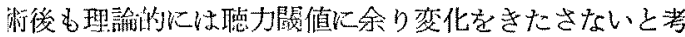

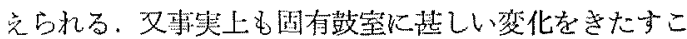
となく経過し，㕛牫存耳小骨の周四に扣こる治㙏機転で

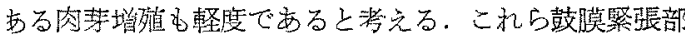

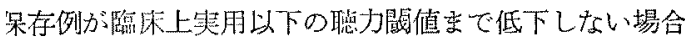
D多い罗之全く比例している。

これK反して三耳小猬を残存させ，これを植皮片で覆

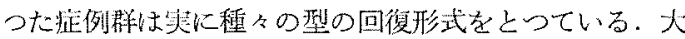

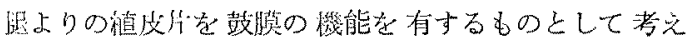
た場合，Wullstein の玉う＼cjkstart型にいれるべきものであ

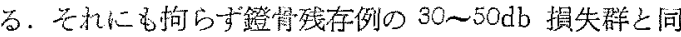

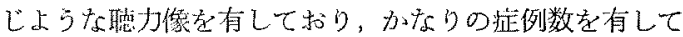

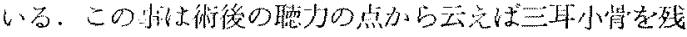

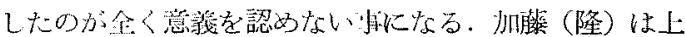

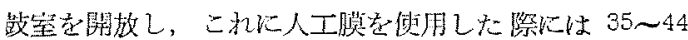

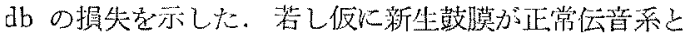

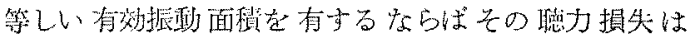
Schmitt の理論式 $a=20 \log \frac{22}{22 \mathrm{~F}-\mathrm{d}}$ 或いは丸山・土 IEの理論式 $a=20 \log -\frac{43}{43 \times \mathrm{F}-\mathrm{di}+\mathrm{K}}$ によつて計筧し

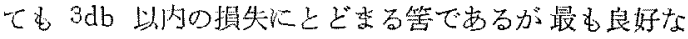

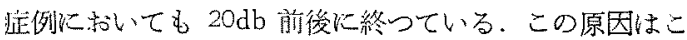

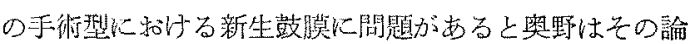
爻のリで述べているが私も同感である。この新生膜が膜

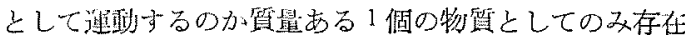
与るのか未だ全く解明されていない，鼓空成形術例を阿 手術してみると，鼓室䣙と新生膜との間には空間が存在

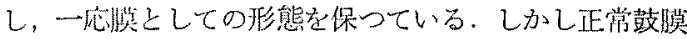

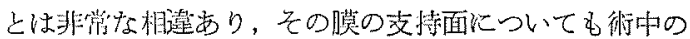
操作方法及び植皮片の㷳いうにより多様にわたりその振

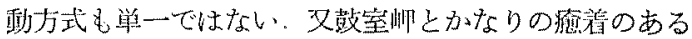
姃例むある。これについて佐藤（智）は鼓室成形術後聴 力に関与る論文において $2000 \mathrm{c} / \mathrm{s}$ にピークの出現する 可能性の多い攲を述べ，これが Wullstein 四型及びN 型に多い亦学述べている。これらの原因として佐藤(智) は Rossberg の云ら衍後の治揬過程に执いて作られた

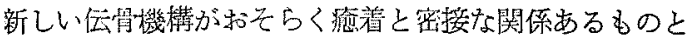

考えており，新生鼓膜の状態がこの特異な所見と大きな 關係を有するのであららと推論している。

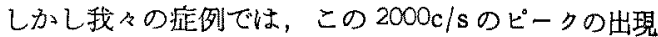

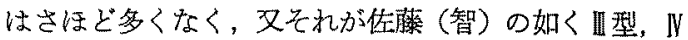
型に出現する求は稀で耳小骨残存例に出現し余り症例数 は多くない，耳小骨保存例が癒着をきたすことは他の症 例群より洘えられず，鼓室成形術直後より聴力の変動を 観察した結果， $2000 \mathrm{c} / \mathrm{s}$ の聴力変動が僅かであり最初は 涔出液その他によつて術前に比較して非常に低下してい た聴力が $2000 \mathrm{c} / \mathrm{s}$ 以下の低音ではすみかかに回復し，又 $2000 \mathrm{c} / \mathrm{s}$ 以上の高音は回復悪く $2000 \mathrm{c} / \mathrm{s}$ を境としてい る.こ礼内耳のインピーダンスが 2000c/s に括いて 埐小である内耳の特性が根本にあると考劣られ，新生膜 の特性がこのピーク出現に密接な関係があるとは考えな い. 更に他の非常に種々の状態を呈する聴力像について は術中所見の観察が肉眼的であり，術後の経過中に関節 の離断や鐙骨の硬化も生ずる症例も考光られ，現在では これな荍密に判断する手段がない，これらを一括して論 ずる所以問題むり，個々の注例についての检討の必要性 を痛感する。

この耳小骨連鎖については古く前述の Wever, Law rence が罢駺を行い中耳機構の障碍が嚾かである場合，

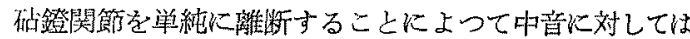
$60 \mathrm{db}$ の損失を見るが低音及び高音に刘する損失は幾分 少いと述べている. こ扎対し Hughson, Crowe, Wever \& Bray は 60〜70db の值を示し，加蒋 (隆)は Hammer 除去により中省 $45 \sim 50 \mathrm{db}$, 低音 35 40db と，これは低音がや〉少い值を示している，彼は更に Amboss 除去した例特いて $500 \mathrm{c} / \mathrm{s} \sim 4000 \mathrm{c} / \mathrm{s}$ K 34.0

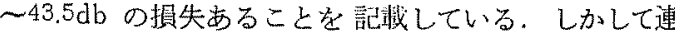

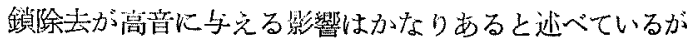
これについては次編の伝音障碍以よる高音低下について の項で述べる，この耳小骨が冝膜に与えられた音響振動 を内耳八伝達する役目を果しておりり，その伝音機能が理 論的叒は实験的に Helmholtz によつて確定されたとも 言える事は今日誰も異論古はさ委ないところである。即 b Helmholtz は豉膜の振動が内耳に伝党られるに当つ て耳小骨連鎖は一体となつて振動しこの運動は体䅡運動 とみなされると考えるのがこれら Helmholtz の説を支 持する最も有力な説，䫅棉説である．Lawrence は実験 的な測定でこの音压比け $1.31: 1$ で $\mathrm{db}$ に鯀算すると 2.5

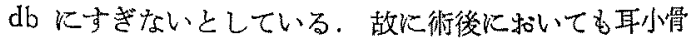
連鎖の運動が制限されたとしてす，臨床上余り大きな差 
がないと理論上では推論される，柏戸は耳小骨連鎖の购慈 能汇関する研究に批いて解剖ないし生理学的並びに各種 嚓床的研究の結果から，耳小骨連鎖の伝音能力には䄪 50db の開きがあると共に振動数の特性に抢いてほら゙ $4000 \mathrm{c} / \mathrm{s}$ を境として低音部並びに高音部分を夫々よく伝 達乙得る2つの特性が例存するものとの推定を下してい るが，この耳小骨連鎖存在の有归及び術れのこれに対与 る操作は踾室成形術後の聴力の変動代対して非常に大き な影響を与兄ている。この結果を最もよく現はしている のが術後鐙骨のみを残して植皮した症例群である，即ち 病変索可及的除去する必要から肉眼的には正常之考兄 られた連鎖を除去した場合と脱白又は真珠堙等の存在又

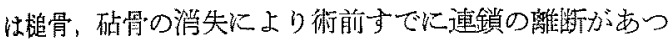
たと考えられる症例に打讨る美異は第2 節で示されてい る. 連鎖除去症例数が他より数に括いて儤つているのは 我分国炕おける耳炎が諸外国に比してその病变が高 度である事を如実に物語り，あくまで病変の完全除去を 目標上しているためである。これらの症例群は退院時聴 力では大差を認めていないが遠隔成續に扔いて上戒例が かなり高い頻度を示している．第】章での結果も同椂で あることは既に述べた。鐙骨存在例及び耳小骨の存在し ない例についてはュメラ又はそれに類似している操作 を行つているが，この編に括ける钼察例では挙げていな い土田の夷験汇上机ば豉室成形術四型に执いて $53 \mathrm{db}$ の損失を有するものがュルメラ装着により $39 \mathrm{db}$ の損失 となり，鼓室成形術了型ではコルメラ装后に上り $44 \mathrm{db}$ が 27db K, 26db が 2Idb K改善されると言う. Stapes の存在は正円空比して卵円空に和ける音の強さと位相 を変化させるが，この2つの空の位瞋によつて括こる位 相变化怯 Békésy によつて測定せられている。この Stapes 子存在しない症例群では㯖覚に関して sound protection が重要な意味を持つている事老我々はすで に知つている. sound protection は2つの component より成立つ，即音の伝播損失と位相の变化である。 Wullstein は共同研究者 Smith の計算より新生裁膜や 植皮片で作つた $50 \%$ sound protection は $30 \mathrm{db}$ に近 く, 耳小骨連鎖のない音王変換の出来ない中耳の症例に 注活近い檤を示寸と述へ，それが50\%，60\%，70\% sound protection のいつれであろうと大きな差はないとし ている、猫で中耳構造を鐙骨まで除去した場合，損失は オへての振動数で同しでなく平均大体 $28 \mathrm{db}$ で理論值の 30db に近いと言う。若し両空が同様に音圧に対して受

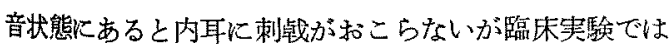

45〜50db の聴覚閾值を示吉ことを知つている，我ふの 症例飞抬いては 20〜30db の值をとつたものが比較的良

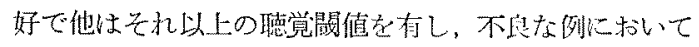

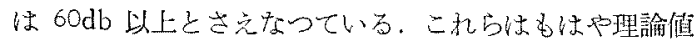

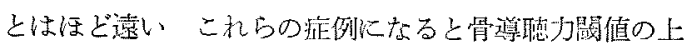

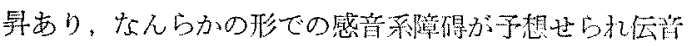

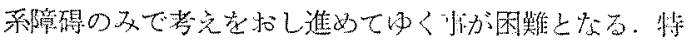

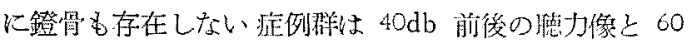
$\mathrm{db}$ 以上の恥力像を特很とする群江分けられるが，後者

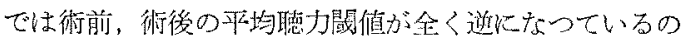

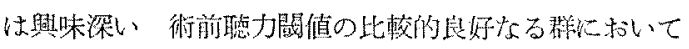
改善の程度も良好であるのに注目すべきであり，こ机は

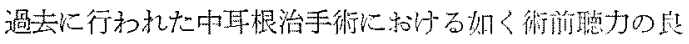

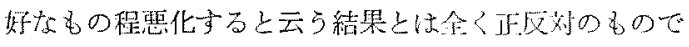
あるが，これは鼓室成形術と中耳根治手術との月的の基

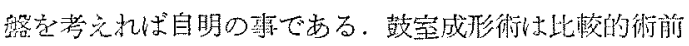
聴力が良好なるもの程回復が容易であるが，缶前聴力閶 值が $60 \mathrm{db}$ 以上のものは術後に恥力を回衡さ也るのが困 難である事を臨床例の観察から知つた。この打は術前の 症例より術後の経過をらかが、知る一助になるである ら. 又この結果から女後藤（修）が慢性中耳炎の早期手 術を提唱しているのは合理的であり，賛成するところで ある。

しかしこの鼓室成形術のかなり重要な部分を占める聴 力の術中より経過を追つた観察は余り行われてはいな

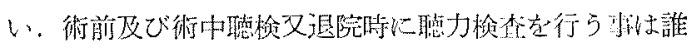
しもが行ら事であるが 術直後上り短時日の間隔を叔、 て㯖力検查を行つた報告はみあたらないこれら術後短

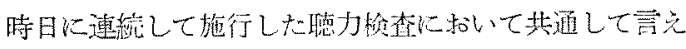

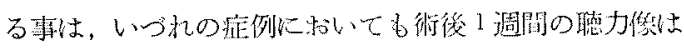

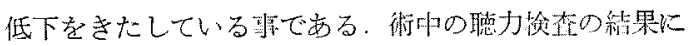
ついては我が教室に括いてすで発表しており，乎術操

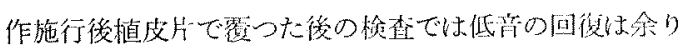
著明でなく，2000 c/s 以上に上最をるる結果が出てい る. Wullstein I型でなさ汪どではないが Wullstein N 型に怙いては1 週間後の㯖力像は 80〜90dbにまで低

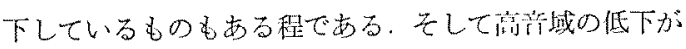
低音域よりも著明である。術後 1 週間の状態公分议物の 貯溜甚だしく，上皮の形成も完成されて扣らず，植皮片 の祭張も瑟く，耳小骨との疮合もきたしていないため音

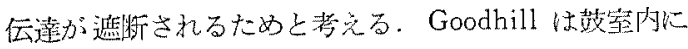
液体を注入入し，その粘度の差異上それに対する C.M. の変化を述へ，粘度の增加と共に高音の低下をきたす才下 
を発琵している，術創が乾燥すると共に聴力も改善し， 約 3 週間後には大体術前の間值又心方礼以上の良好な状 態回復している。この場合高音の回復しないものは退 院時をで变化しないこの章で倠察した症例群では術前 上り低下した症例はない。

こ礼らの結果をみると鼓室成形術は植皮片で覆つた時 $2000 \mathrm{c} / \mathrm{s}$ の高音域にやや上最を認めるがその後主として

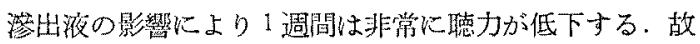

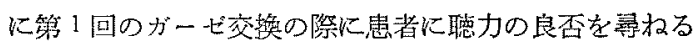
のは然意味であり，この場合聴力の低下を訴えられても 術中の操作失敗, 又心付耳炎等を疑う症状の存在を認め なければ, 聴力は術後の術創の上皮化, 乾操と共に改善 されてゆく、3〜4週間で聴力は安定し退院時の聴力検 盗成結汇示されるように変動を示すこの変動に関して は病変の除去をできる限り小範田の侵毙にとどめめ連鎖 を残した症例群に聴力改善の期待がかけられる。しかし てその改善忖全周波数領域に及ぶ場合もかなりあるが， 高音の改善はやや因難である。しかし高音域は更に年月 を䌯過して改善されていく可能性を有している。このよ

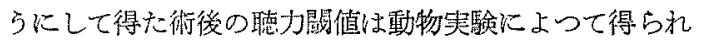
た理諭值と近似する值を示す理想的な症例る多数存在す る一方，その反対例もある事恃事実である。

Wullstein の述べているよらな理論俌优達する事は 稀であるが，その値に達しない事はWullstein 自身む 認めて扎り 15〜30dbをもつてその成績を良好と判定 している.このような东性に三耳小骨を残存せしめた 症例で理論值に達しない症例群がかなり多く，耳小骨連 鎖の取り扱い方に今後多くの問題を残すと考兄られる。 肉眼的に連鎖が正常であれば聴力の点からはそのまま残 すべきであるが，その残した連錤がそのままの機能を保 存していると考灾られない症例があり，連鎖周困の肉岽 の処置又は固有鼓室の搔爬の問題などがある，術前噹力 良好なる群恃術後 $5 \mathrm{db}$ 前後低下する事があり得るが実

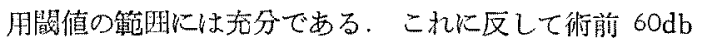
以上の気導聴力を有するるのに対しはたと党手術を施行 しても去の効果を期待できる確率は少く，鼓室成形術の 適応をきめる一つの手掛りとなると信ずる。

要するに手術施行後の伝音機構は正常之は非常に異つ でり，一つ一つの正常な状態より变化させた単純な実 験条件からは測り知れない、複雑な要素をもつている。 してその個タの条件が音伝播機構偟影響を与えていく。 術後の聴力像はそれらすべての component を含んだ集 産物であり，それが又感覚器管であることからより複雑
になつてくる、しかしそれ以前に考えなければならない のは炎症の消失である。何故なら耳小骨む存在せず，両 空になんら操作をほどこさない症例で聴力改善の見られ る場合，その原因が桨症の消失に西つたと考之られる症 例も少くないからである、炎症の完全な消失をきたさね ば伝音系の修復は全く無意味である。

私の観察症例の結果が他の報告と多少差異を示してい、 るのは，植皮の方法に起因寸る獄が多いと考光る。非常 にうすい植皮片をとり覆ら事は後汇穿孔の危険を抏こす こと大であつても好結果を生み出していると考える. 大 退より採取した植皮片は薄くともとの経過中に壊死を物 こすことなく，又直接に支持面に接して和らずとも上皮 形成は可能である。

現在まで正常動物に上る障碍実験が行はれ，中耳伝音 機櫣に対してかなりの解明が行はれているが，かくも多 様に方たる術後聴力像をはつきりと把握できない原因の 一つは新生嫴膜の特性が全く不明な点にある。ごく僅か の变化によつても伝音機構は变化し，巽つた聴力像を示 すのであららが，術後においては新生㪍膜の支持点も明 らかにし得ないのである。

叉この術後聴力像について與味あるのは種々の変動を 示与高音域の態度である. 完全な伝音棌碍耳の高音低 下及びその回復の遅延，更に長期間後の好結果について である.

私は新生鼓膜は膜としての作用を有するとの仮定の上 にたつて術後の成續を観察したが，嵒床例のみではそれ を笑証し得なかつた。

今後残された課題はこれらの点を追求してゆく束にあ り，高音低下については次編で検討する。

\section{第 VI章 結論}

第 1 編で敋室成形術後の聴力は 1 年を経過してもな汪 变化してゆくものであり，特に高省域は更に上帠する傾 向のある事索知つた。しからば術後聴力はどの上らな経 過をたどつて形成されてゆくか，退院時に打讨る噹力上 1 年後の聴力は各手術型，各周波数間にどのような関係 を有するか，又動物実験仩得られた值と実際の臨林 例との間にどの程度の相違が認められるかを追求した

その結果, 鼓室成形術後必ず聴力の低下をきたし，し かしこの状態によつてその後の経過の良否を拈それる必 要なく術創の幹燥と共に德力は回復する.特にこの際高 音域の变化法著しい

又第 1 編で述べた如く連鎖を破壊せずに手術を施行し た症例群が各周波数共に上昇する傾向を有し，退院時と 
1年後の差を大きくしている.そして大体症例の $50 \%$ に かいて実験值に近似しているが高音域の回復は困難であ る。中耳根治手術後に呿けるような術前聴力良好なもの
に低下を認める事少く，鼓室成形術に和いては術前德力 良好なもの程術後の好結果を期待乙得, その限界は術前 気導聴力 $60 \mathrm{db}$ をもつてすべきである。

\section{第3 編 伝音障碍による高音低下について}

\section{第 I 章 緒 言}

現在まで行はれた伝音障碍の実験に怙いては常に低 暗障碍がその変化の主体をなしている結果を得ている。

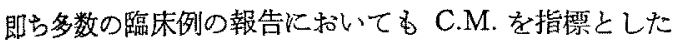

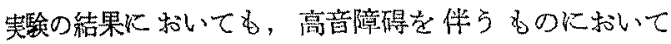
る，常淿低障碍が主体であつて高音障碍のみを認めて Wない.

しかるに私が検索した鼓室成形術後の患者については 術後畽力回復の状態が低音域で良好である事は伀音系修 徼といら点からして当然であるが，高音の回復もしばし 壮認められている。しかし高音域の及が低下したり，低 下のま主不変の場合がある。しかも骨学は正常であつて

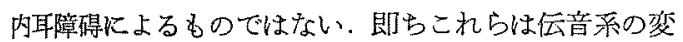
化によって生じたるので，低音域，中音域の回復には好 都合であつたが高音域の回復にはなんら効果を生じ得な 加た症例である。ここに打いて伝音系の障碍による高

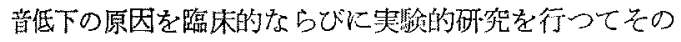
因子を解明せんとした。

\section{第I章 臨床例による研究}

第1 節 研究対象及び研究方法

炤和 29 年から炤和 33 年末で名大耳鼻咽㩔科教室で鼓 室成形術を施行し， 1 年内至 2 年後に聴力を検查した 416 耳及び䩳膜形成術及び 外耳道保存の豉室成形術施行 の10耳である. 研究力法は聴力像を低音域，中音域高音 域分姑，その高音域の回復状態を主として観察した。

\section{第 III章 成績}

i) 根治手術型厄和ける検討

術後外耳道と乳様洞が一つの空洞となつたものについ て高音域の変化を中心として聴力の回復形式を分類して みると第 12 表に示すようである，即ち第1型は全音域

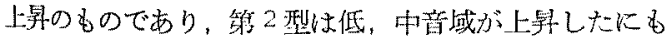
拘らず，高音域が变化しなかつた場合であり，第了型は 低，中音域情上昇したにも拘らず高音域はか克つて低下 した場合であり，第 4 型は低，中音域法不变，高音域は 上年したものですり，第 5 型虫低，中音域がいかなる回 復形式をとるにせよ高音域が低下した場合である．第6 型のその他々は各音域の回復形式が全く一定の傾向走示
表 12 回復形式の分穎

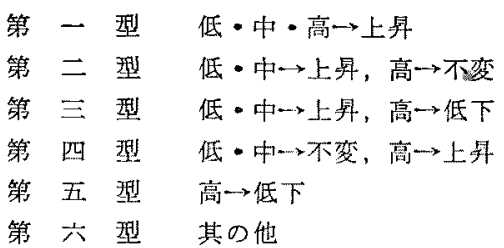

表 13

\begin{tabular}{|c|c|c|c|c|}
\hline 回 & 復 & 形 & 式 & 症例数 \\
\hline 第 & & - & 型 & 59 \\
\hline 第 & & E & 㤠 & 25 \\
\hline 第 & & $\Xi$ & 珰 & 8 \\
\hline 第 & & 四 & 型 & 1 \\
\hline 第 & & 不 & 型 & 114 \\
\hline 第 & & 六 & 㑭 & 209 \\
\hline 采 & & & 妏 & 416 \\
\hline
\end{tabular}

さないものである。

そこで本检索対续となつた416耳炕ついでの程度に

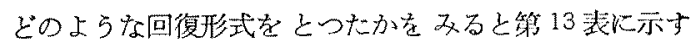
ようである。即占

第 1 型 59 例 第 2 型 25 例 符 3 型 8 例 筙 4 型 1 例 第 5 型 114 例 第 6 型 209 例 である，この成績からして，第 5 型の術後高暗低下する むのが多い事であり，それに比してこれから追求せんと する高音域のみの 回復不良の状態は比較的少い事であ る、特炕高音域のみが上昇する症例は非常に少い。

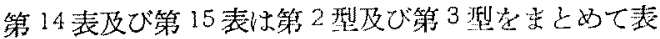
に作製したものである。

第 2 型の症例群についてては総数 25 例中 15 例小骨尊䍡

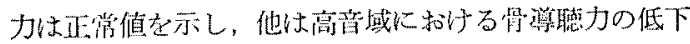

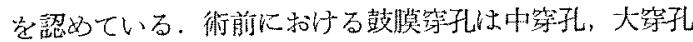
が多く, 術前の気道聴力は中等度の難衈を示している。

上䓩室，中故室の病変は軽度であり，このため 25 例 中 16 例儿三耳小骨を残存し得ている。

耳小骨の運動性は比較的良好なものが多い，第3 型の 症例群疒籍 15 表に李とめて示してある。症例数は第 2 
表 14 第 二汪 (上・上・不) 症 例

\begin{tabular}{|c|c|c|c|c|c|c|c|c|c|c|c|}
\hline & \multirow{2}{*}{$\begin{array}{l}\text { 衙 } \\
\text { 鼓膜所前 }\end{array}$} & \multicolumn{3}{|c|}{ 聴 } & 力 & \multirow{2}{*}{ 上 鼓 室 } & \multirow{2}{*}{ 鼓室 } & \multirow{2}{*}{\multicolumn{2}{|c|}{$\begin{array}{ll}\text { 耳 } & \text { 骨 } \\
\text { 連 } & \text { 鉬 }\end{array}$}} & \multirow{2}{*}{ 牫 存 骨 } & \multirow{2}{*}{$\begin{array}{l}\text { 運 } \\
\text { 動 } \\
\text { 性 }\end{array}$} \\
\hline & & 低 & 中 & 高 & 骨導 & & & & & & \\
\hline 1 & & $\begin{array}{l}55 \\
37.5\end{array}$ & $\begin{array}{l}63.5 \\
36.6\end{array}$ & $\begin{array}{l}55 \\
60\end{array}$ & 高音低下 & 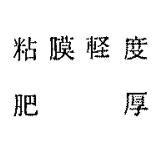 & $\begin{array}{l}\text { Binde- } \\
\text { gewebe } \\
\text { 僬 }\end{array}$ & 保 & 存 & $\begin{array}{l}\text { Hammer } \\
\text { Amboss } \\
\text { Stapes }\end{array}$ & 良 \\
\hline 2 & & $\begin{array}{l}45 \\
22.5\end{array}$ & $\begin{array}{l}38.3 \\
20\end{array}$ & $\begin{array}{r}36.6 \\
35\end{array}$ & 正 常 & 硬い肉芽 & 曆い肉芽 & 保 & 存 & $\begin{array}{l}\text { Hammer } \\
\text { Amboss } \\
\text { Stapes }\end{array}$ & 良 \\
\hline 3 & & $\begin{array}{l}52.5 \\
35\end{array}$ & $\begin{array}{l}66.6 \\
45\end{array}$ & $\begin{array}{l}86.6 \\
81.6\end{array}$ & $\begin{array}{l}\text { 高音低下 } \\
\text { 著 明 }\end{array}$ & 橋部 除 去 & 肉芽 & 何るな & L & 何子なし & \\
\hline 4 & & 47.5 & 46.6 & 40 & 正 常 & 硬い附荡 & 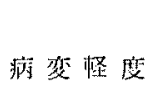 & 除 & 去 & Stapes & 瓦 \\
\hline 5 & & $\begin{array}{l}45 \\
25\end{array}$ & $\begin{array}{l}45 \\
25\end{array}$ & $\begin{array}{l}35 \\
45\end{array}$ & $\begin{array}{c}8000 \mathrm{c} / \mathrm{s} \\
\text { や低下 }\end{array}$ & Chole. & & 除 & \pm & Stapes & 底 \\
\hline 6 & & $\begin{array}{l}67.5 \\
30\end{array}$ & $\begin{array}{l}80 \\
30\end{array}$ & $\begin{array}{l}66.6 \\
71.8\end{array}$ & $\begin{array}{c}8000 \mathrm{c} / \mathrm{s} \\
\text { 低下谓䀧 }\end{array}$ & $\begin{array}{l}\text { 七ンキ惟 } \\
\text { 粘 膜 }\end{array}$ & 肉芽充 䔩 & 除 & 去 & Stapesplatte & \\
\hline 7 & & $\begin{array}{l}60 \\
22.5\end{array}$ & $\begin{array}{l}61.0 \\
33.3\end{array}$ & $\begin{array}{l}43.3 \\
43.3\end{array}$ & $\begin{array}{l}\text { 低中, 低下 } \\
\text { 術後に正常 } \\
\text { にもを゙る }\end{array}$ & $\begin{array}{l}\text { 肥原 せる } \\
\text { 肉芽 }\end{array}$ & $\begin{array}{l}\text { 肥檿世艺 } \\
\text { 肉芽 }\end{array}$ & 除 & 去 & Stapes & 良 \\
\hline 8 & & $\begin{array}{l}52.5 \\
30\end{array}$ & $\begin{array}{l}58.3 \\
36.6\end{array}$ & $\begin{array}{l}56.6 \\
46.6\end{array}$ & $\begin{array}{l}3000 \\
4000 \mathrm{c} / \mathrm{s} \\
8000 \\
\text { 低下著明 }\end{array}$ & Chole. & $\begin{array}{l}\zeta \text { れ } \\
\text { pars tensa } \\
\text { 保 存 }\end{array}$ & 保 & 存 & $\begin{array}{l}\text { Hammer } \\
\text { Amboss } \\
\text { Stapes }\end{array}$ & 不明 \\
\hline 9 & & $\begin{array}{l}65 \\
30\end{array}$ & $\begin{array}{l}55 \\
30\end{array}$ & $\begin{array}{r}40 \\
43.3\end{array}$ & 正 & & 粘膜肥曆 & 保 & 存 & $\begin{array}{l}\text { Hammer } \\
\text { Amboss } \\
\text { Stapes }\end{array}$ & 良 \\
\hline 10 & & $\begin{array}{l}37.5 \\
20\end{array}$ & $\begin{array}{l}46.6 \\
26.6\end{array}$ & $\begin{array}{l}36.6 \\
36.6\end{array}$ & 正 & 桥 部 残 存 & & 保 & 存 & $\begin{array}{l}\text { Hammer } \\
\text { Amboss } \\
\text { Stapes }\end{array}$ & 良 \\
\hline 11 & & $\begin{array}{l}40 \\
22.5\end{array}$ & $\begin{array}{l}41.6 \\
20\end{array}$ & $\begin{array}{l}48.3 \\
58.3\end{array}$ & $\begin{array}{c}8000 \mathrm{c} / \mathrm{s} \\
\text { 軽度低下 }\end{array}$ & Chole. & $\begin{array}{l}\text { pars tensa } \\
\text { 保 存 }\end{array}$ & & & $\begin{array}{l}\text { Hammer } \\
\text { Stapes }\end{array}$ & 不明 \\
\hline 12 & & $\begin{array}{l}32.5 \\
20\end{array}$ & $\begin{array}{l}36.6 \\
25\end{array}$ & $\begin{array}{l}31.6 \\
31.6\end{array}$ & 正 & Chole. & & 除 & 去 & $\begin{array}{l}\text { Amboss } \\
\text { Stapes }\end{array}$ & \\
\hline
\end{tabular}




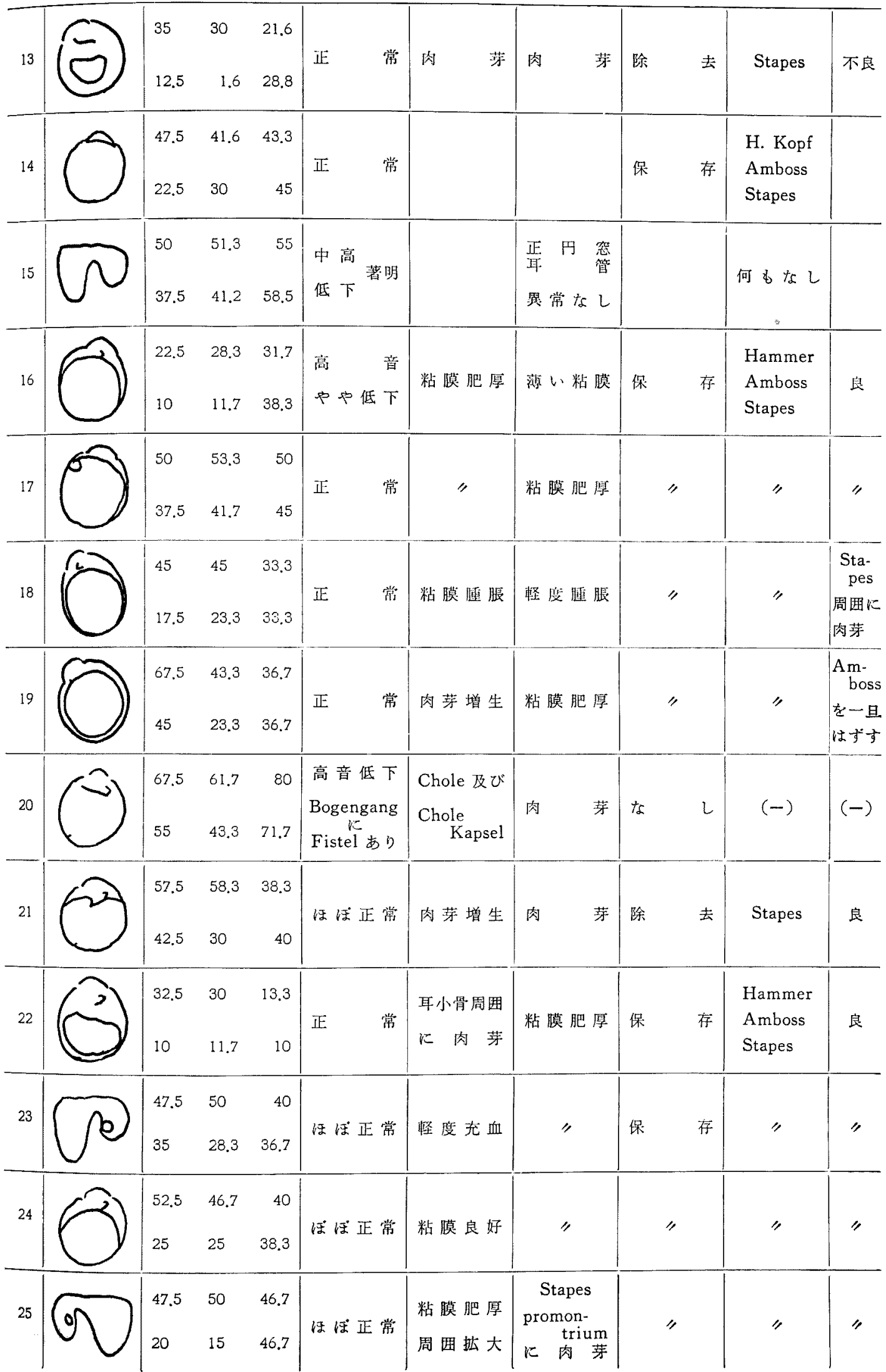


表 15 第 三型（上・上・低）症 例 群

\begin{tabular}{|c|c|c|c|c|c|c|c|c|c|c|}
\hline & & & 聴 & & 力 & 1. 踩 5 & 宮 & 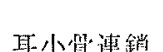 & 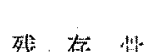 & 通 \\
\hline & & 但 & 帱 & m & 捐 泠 & 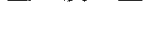 & & & & 性 \\
\hline 1 & & $\begin{array}{l}60 \\
20\end{array}$ & $\begin{array}{l}36.6 \\
21.6\end{array}$ & $\begin{array}{r}35 \\
56.6\end{array}$ & 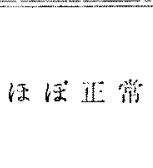 & 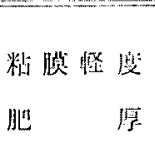 & $\begin{array}{l}\text { Binde- } \\
\text { gewebe } \\
\text { 僬 }\end{array}$ & $\begin{array}{l}\text { Amboss } \\
\text { 器脚なL } \\
\text { Hammer- } \\
\text { griff なL } \\
\text { 除望 }\end{array}$ & Stapes & 主 \\
\hline 2 & & $\begin{array}{l}55 \\
30\end{array}$ & $\begin{array}{l}53.3 \\
28.3\end{array}$ & $\begin{array}{r}28.3 \\
45\end{array}$ & 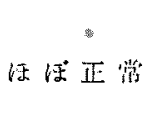 & 肉 & 料膜肥曆 & 存 & $\begin{array}{l}\text { Hammer } \\
\text { Amboss } \\
\text { Stapes }\end{array}$ & $\begin{array}{l}\text { 肉犽に } \\
\text { 賏はる }\end{array}$ \\
\hline 3 & & $\begin{array}{l}35 \\
25\end{array}$ & $\begin{array}{l}50 \\
38.3\end{array}$ & $\begin{array}{l}36.6 \\
63.3\end{array}$ & 汪汪正敌 & 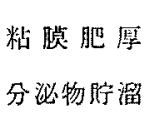 & 粘膛浮腫状 & 除 & Stapes & 艮 \\
\hline 4 & & $\begin{array}{l}40 \\
27.5\end{array}$ & $\begin{array}{l}40 \\
26.6\end{array}$ & $\begin{array}{l}28.3 \\
53.3\end{array}$ & $\begin{array}{l}4000, \\
8000 \mathrm{c} / \mathrm{s} \\
\text { 火怪度低下 }\end{array}$ & 肉 & 肉 & 保 & $\begin{array}{l}\text { Hammer } \\
\text { Amboss } \\
\text { Stapes }\end{array}$ & 良 \\
\hline 5 & & $\begin{array}{l}22,5 \\
0\end{array}$ & $\begin{array}{l}16.6 \\
18.3\end{array}$ & $\begin{array}{l}23.3 \\
53.3\end{array}$ & ほぼ正常 & 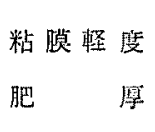 & 粘膜肥㫗 & 存 & $\begin{array}{l}\text { Hammer } \\
\text { Amboss } \\
\text { Stapes }\end{array}$ & 底 \\
\hline 6 & & $\begin{array}{l}22.5 \\
12.5\end{array}$ & $\begin{array}{l}45 \\
25\end{array}$ & $\begin{array}{l}35 \\
60\end{array}$ & 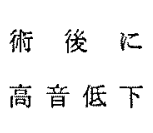 & 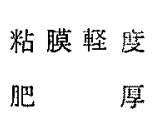 & $\begin{array}{l}\text { 粘膜怪摸 } \\
\text { 肥厛 }\end{array}$ & 保 & $\begin{array}{l}\text { Hammer } \\
\text { Amboss } \\
\text { Stapes }\end{array}$ & 真 \\
\hline 7 & & $\begin{array}{l}42.5 \\
25\end{array}$ & $\begin{array}{l}40 \\
23.3\end{array}$ & 32 & 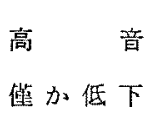 & 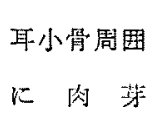 & 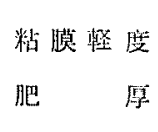 & $\begin{array}{l}\text { 保 存 } \\
\text { (但七 A. S } \\
\text { 切断) }\end{array}$ & $\begin{array}{l}\text { Hammer } \\
\text { Amboss } \\
\text { Stapes }\end{array}$ & 艮 \\
\hline 8 & & $\begin{array}{l}50 \\
32.5\end{array}$ & $\begin{array}{l}41.7 \\
20\end{array}$ & $\begin{array}{l}36.7 \\
46.7\end{array}$ & 正 & 闪 & 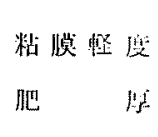 & 保 & $\begin{array}{l}\text { Hammer } \\
\text { Amboss } \\
\text { Stapes }\end{array}$ & 良 \\
\hline
\end{tabular}

型より少い，骨導聴力は第 2 型群と同様に正常値を有す るものが大体半数を占めて括り他の蓜例はやはり高音域 に低下を認めている，術前に蚂ける鼓膜穿孔も中及び大 穿孔多く，上鼓室，中鼓至の病変る墐かであり，三耳小

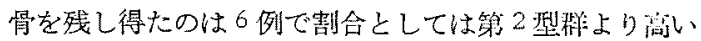
值を正している。

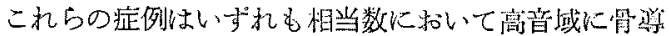
媤力の低下を認めて特り，これによつて䧚音域に特ける

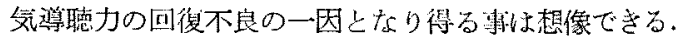

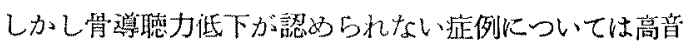
域が変化を示さなからた原因は不明であり，連鎖に対吉

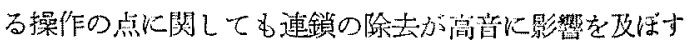
と断語でさない。

ii) 外耳道保存症例飞抽占る检剖

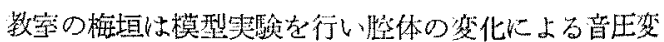

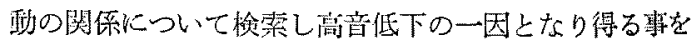


報告している。

このため臨床例について鼓膜形成術及び乳样润修空の みによつて後部の乳梯洞を削開せず外耳道を保存上しめ た泟例について観察した．全症例は10例でそのらち2 例䏓完全な故膜形成術のみを施行されており，他の8例 は乳梾洞型空によつて病変軽度であることるたしかめて 外耳道を保存したるのである。鼓膜形成の 2 症例小いず れも三耳小骨を完全に保存しているが，砧鐙関節を再形 成したり砧骨の欠除，又はFascia Bindegewebe に上 るコルメラを作製したものもある。第31 図から第40図 までがこれら症例群のオーヂオグラムである。いずれ必 退院時琼力と術前聴力を比較している.

図 31 第 1 例 鼓膜形成術

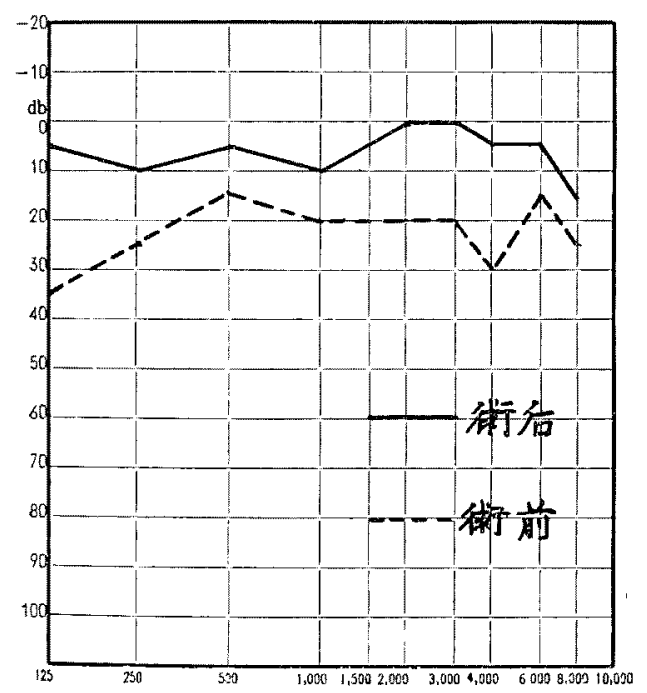

图 32 第 2 例 敏膜环成街

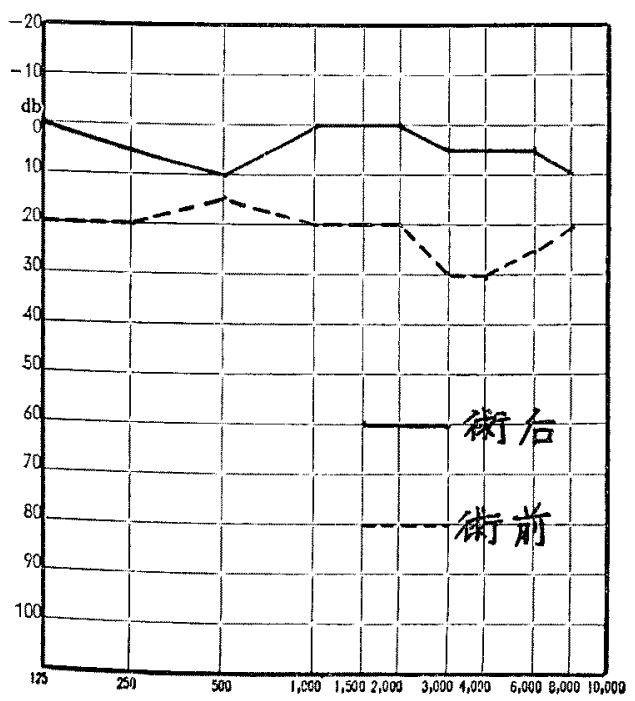

図33第 3 例

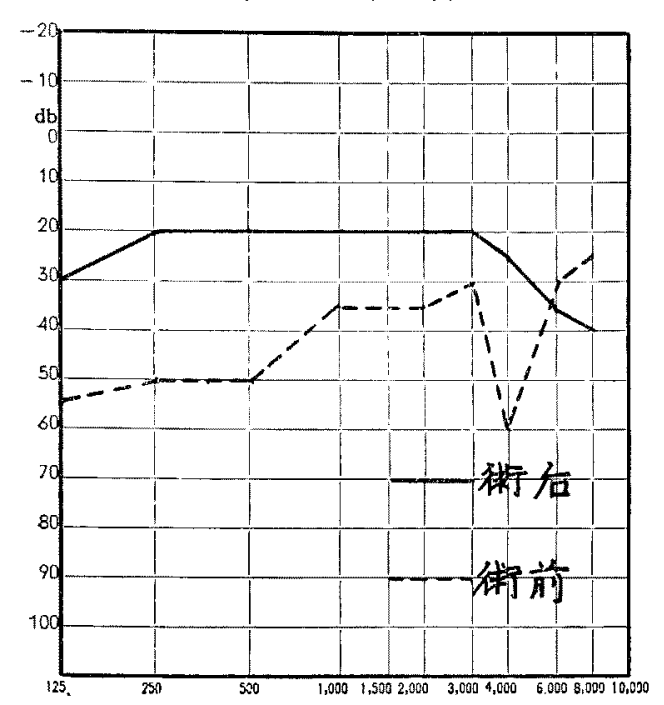

图 34 第 4 例

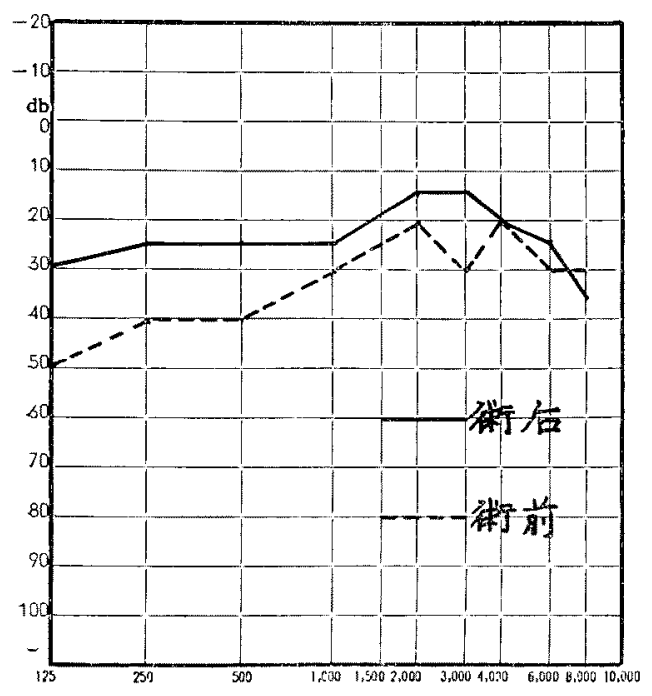

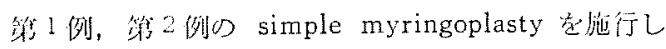
たものは全音域にわたり上帠して闇值が大作 $10 \mathrm{db}$ 前後

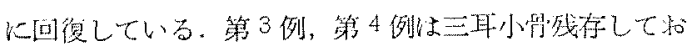
り，外耳道の削開は己れていないか３000 c/s, $4000 \mathrm{c} / \mathrm{s}$

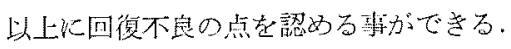

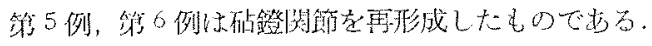

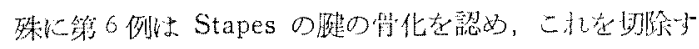

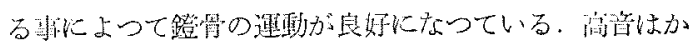
えつて低下をきたしている。 
图 35 管 5 何

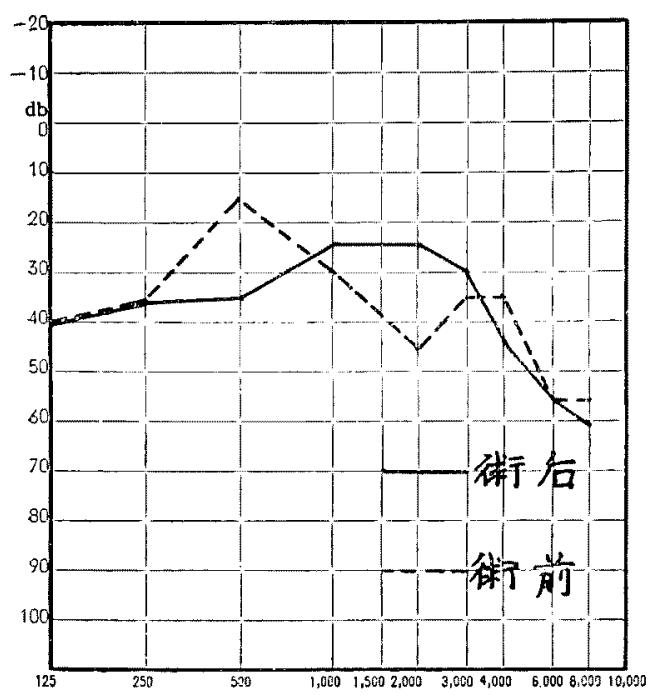

国 36 扰

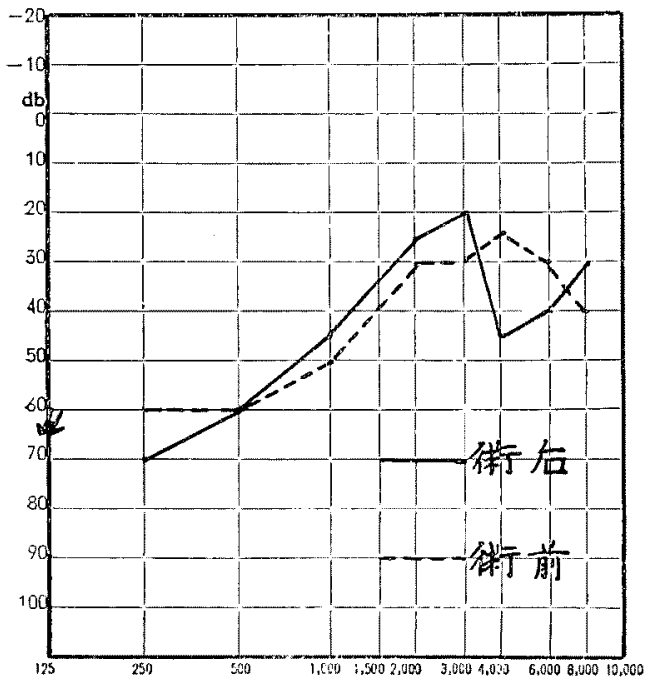

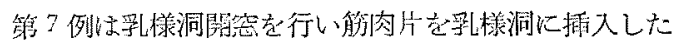
ものでるる。高音の低下が著明である。

第8例な濑骨が硬く固定し，砧骨を認めないものであ

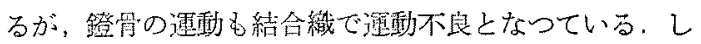

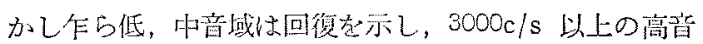

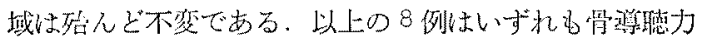
に低下老認めていない。

第9例，符10例はいずれも Fascia Bindegewebe
図 $37 \quad$ 第 7 例

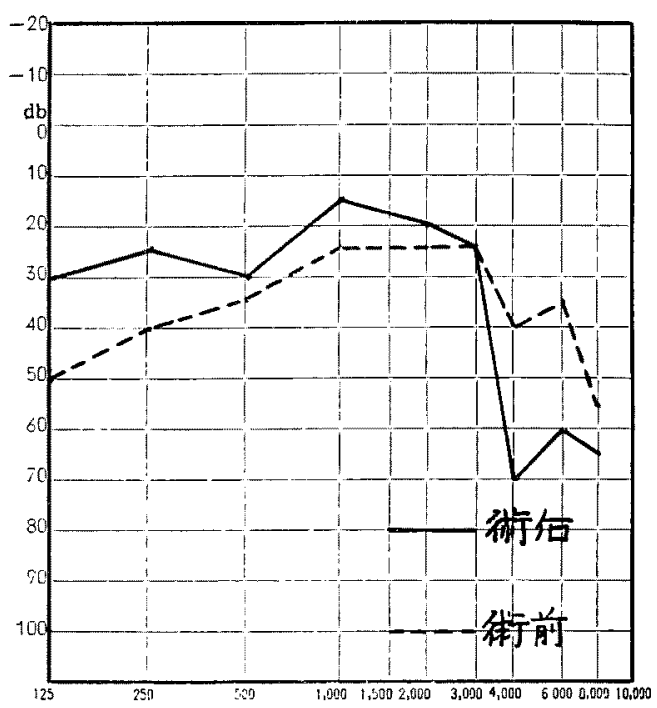

图 38 第 8 例

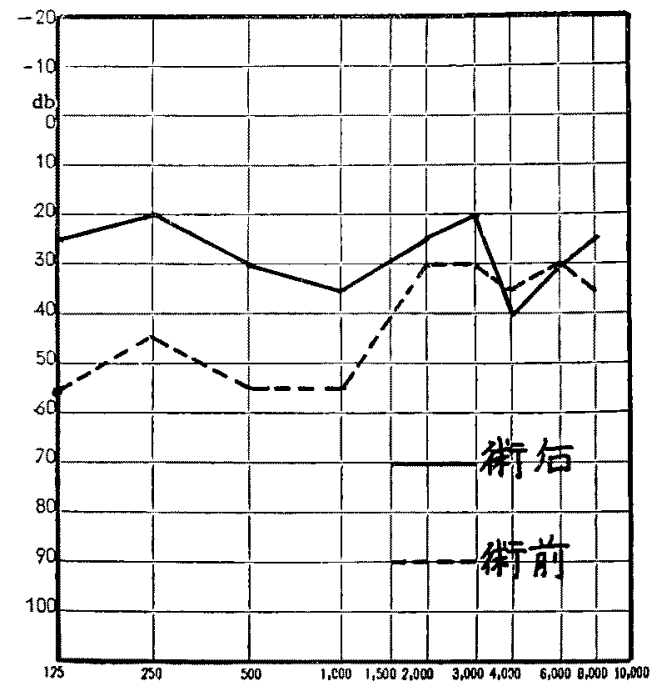

によつてコルィラを作筡したものである，第9例は $4000 \mathrm{c} / \mathrm{s}$ より高音域に念激な骨望㯖力低下を諗め，第 10

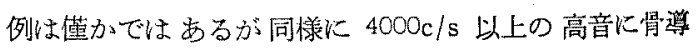
恥力の低下を示している。

これらの症例は孚様洞の削据は行はれて扣らず外耳道

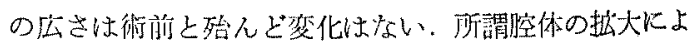

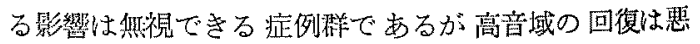
?，不変か又双低下を示与ものが大多数なのである。 
图 39 第 9 例

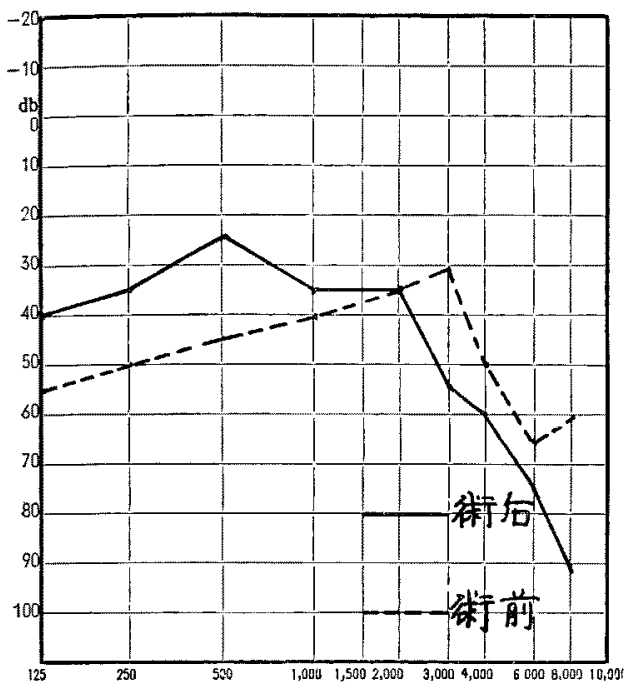

图 40 第 10 例

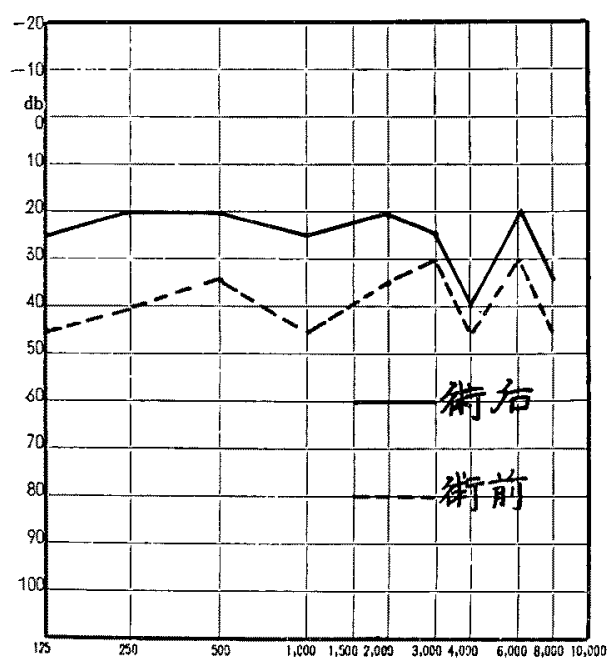

iii）術後経過による高音域の移動について 詳紐は第 2 編第 I章に記述ずみである。

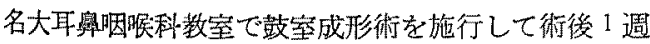
間每に㯖力検查を行つた 13 耳の経過について追求した。

I型の 4 例については，いずれも術後 1 週間で全音域 にわたつて聴力低下をきたしておる，3000 c/s 以上の高 音域に和いて藷明である。

この高音域の低下が 1 週後より回復してきており3週

後，4週後に至つて街前の level に近づき又はをれよ
り良好な状態となる。

【型の手術定行つた1例は，同様比 1 週徭全音域に低

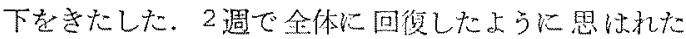

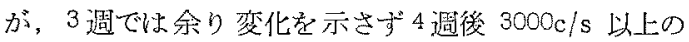
高音域は術前より低下を示した状態となつている。

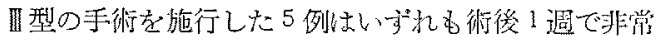

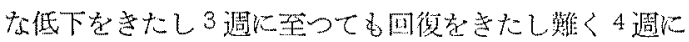
至つて術前と同じ level に回復したもの2 例で他修 前より低下をきたした。

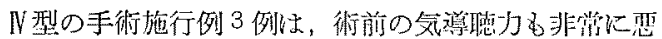
く 1 例怘全く全音域侄化を示していないか，他の 2 例 は術後高至城の低下方改善され，術解の level 上り上 氧している。

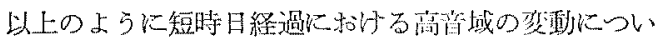

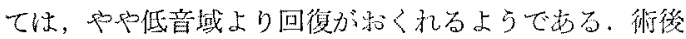
1 週経過の術創ま分泌物非常に多く植皮片もまだその形

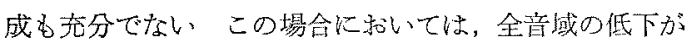

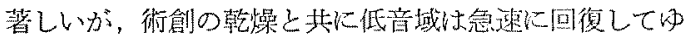

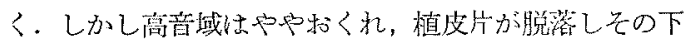
面に新生膜が形成された頃より回復してゅくのである。 これによつて高学域の变化は新生膜に密接な閣䌽を有

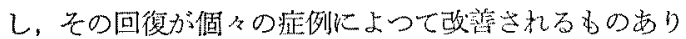
又低下をきたすもののあるところから，新生慕の形成が 一つの因子となつてい石事老推定し得る。

第3節 小括

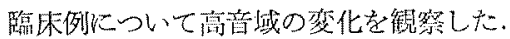

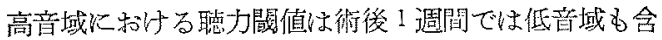
めて非常な低下を示している，しかしこの低下はその後

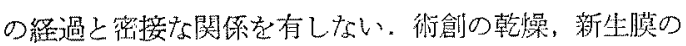

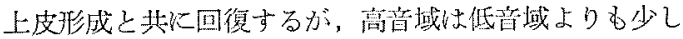

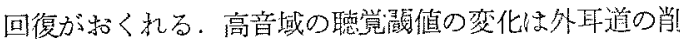

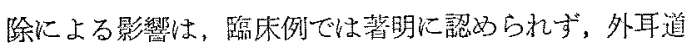

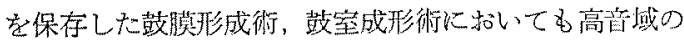

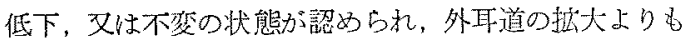

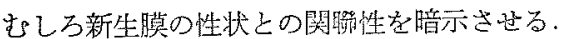

\section{第 IV 章 商音低下の実驗的研究}

第 1 節 武験方法

a) 実疑村料

プライエル反応正常な250〜300gr.のーヒルモツトを渎 用した。

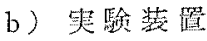

第 41 图がこの䍒験に使用した㳖置のブロックダイア グラムである，音源としては检河制測音 1 号 C.R. 発振 
図 41 Block Diagram

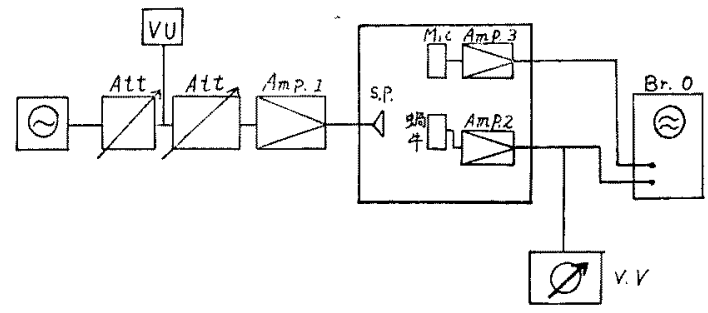

器を用いて，それを8インチのパイオンフのスピーカー

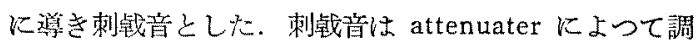
整できるよらにしてある、スピーカーとモルモットの耳 との閣隔は約 $50 \mathrm{~cm}$ とした，C.M. をとり出す電極は鋼 鉄針を使用した。

c) 察駼方法

クロールブロマヂン及び10\%ウレタンにて麻醉したモ ルモットに気管切開敠施行して気道を確保し, 次いて鼓 室を開放して蜡牛を明視下に扣き，螎牛の基底迴枟に小

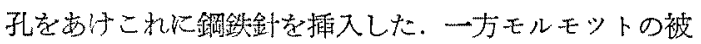
检耳より $50 \mathrm{~cm}$ の距離化あるスビーカーより $250 \mathrm{c} / \mathrm{s}$ から $8000 \mathrm{c} / \mathrm{s}$ 末で純音を刺㦸音として与え, それに よつて生ずる C.M. を雨入した鋼鉄針より尊いて懔幅

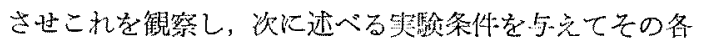
々について数値の差を観察した。

第2 節 等験条件

a）上鼓室への硬石臂注入

粎科用石䇏を使用してこれを水にてとき，水との混 合比を变化させて耳小骨周囲へ充搷した. そしてその後

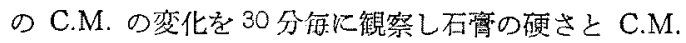
との関係をみた。

b）豉膜变化とその回侯

i) 亄膜剝離

ii）鼓膜穿孔とその修復

正常耳において攱膜を 4 時から8時の位置にわたつ

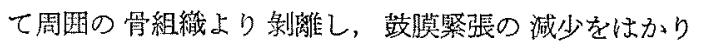
C.M.の変化をみた

次化鼓膜穿孔を括こし後にその穿孔を厚さ的 $0.04 \mathrm{~mm}$ 及び約 $0.08 \mathrm{~mm}$ の市販のポリェチレン膜とビニール膜 にて閉錤して同様に C.M. の変化を観察した.

籍 3 節 柴験成経

i）上哱室への硬石而注入

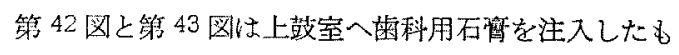
ので，第 42 図小石営と水を $2: 1$ の容量比で混合泥状に
し耳小骨周国に注入した，第 42 图上はその注入範因が 少なく，第42 図下はその範围を少し抎げたるのである. 更に第 43 図は混合比を3:1 としたものの值を示してい る. 即ら後者の 2 例が粘度の高い石刑泥を注入した形に なる、入れた直後より C.M. の值を30 分每儿観察し、 全く值の変化しなくなるまで観察した data である.

いずれの場合に执いても注入直後より低音の障碍が認

図 42 耳小骨周囲への石高注入

No. 1

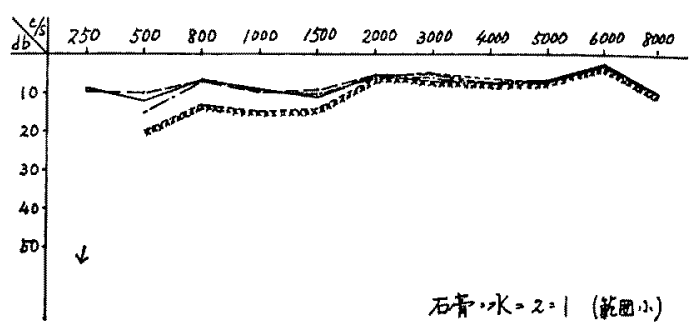

No. 2

No. 2

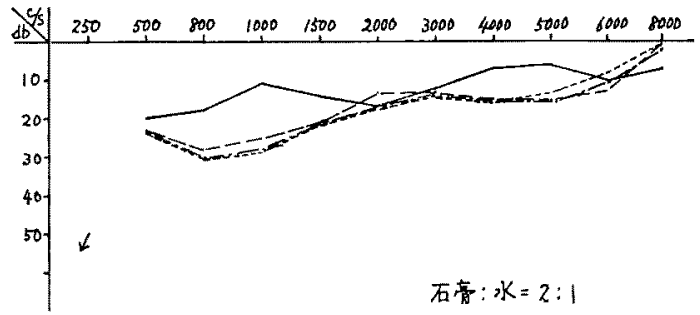

No. 3

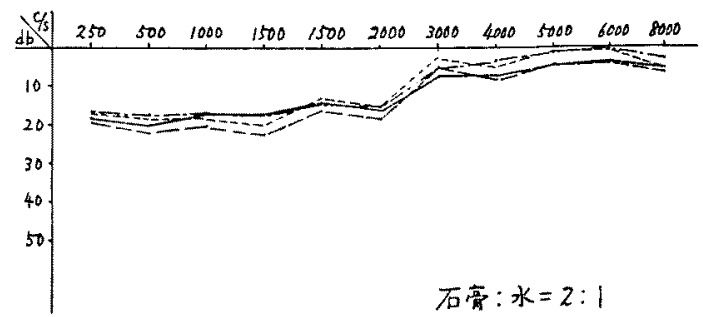

No. 4

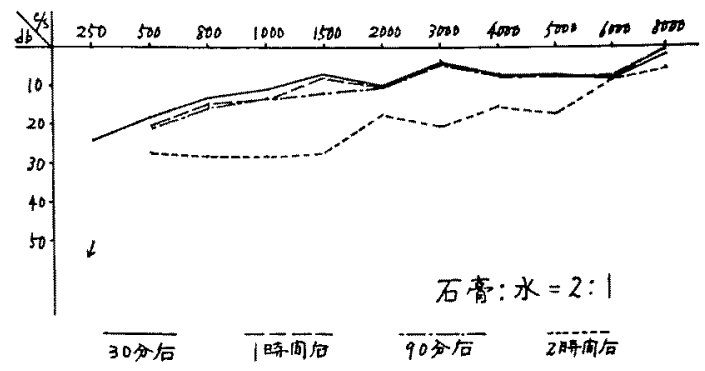


No. 1

图 43 耳小骨䧓围への石霄注入

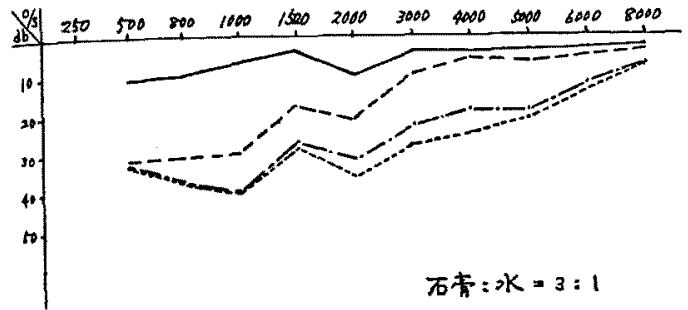

No. 2

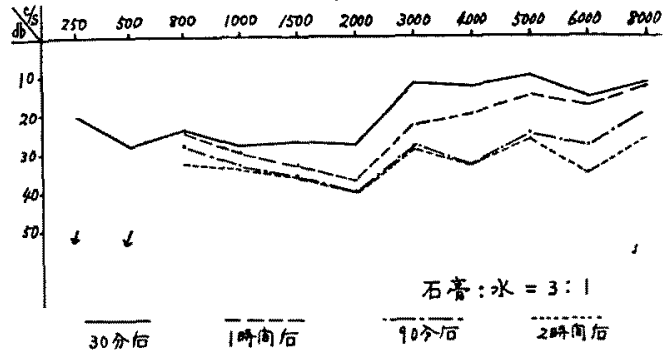

められている，耳小骨周团への注入の搪大をはかればそ れに伴つて低音の障碍は著明となつており，時間の経過 に従つて石管の硬さが增大し，并れに比例して C.M. の反伦低下が認められる。

この6例の共通点はいず机も最初に $250 \mathrm{c} / \mathrm{s}, 500 \mathrm{c} / \mathrm{s}$ 等の低音の低下をきたし時間の経過，即ち石膏の硬さの 增加往つて徐々汇高音が障碍されて行く点にある. 石 高の硬さが全く一定すると C.M. が安定する，この場

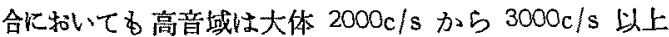
は余り急激な低下を示していない，がしがし石骨の硬さ の增大滈高音の低下に著明な影響を与支ている。

ii）鼓膜变化とその回復

a) 鼓膜剥離 第 44 図

鼓膜剩離は全周の $1 / 3$ Kわたつて注意深く剥滩した。 ここに挙げるものは剝離症例の 3 例である.大体水平の 低下をきたしており，10db 前後の損失である。特に高 音のみ低下する傾向は見あたらない，

b) 鼓膜穿孔第 45.46 図

鼓膜穿孔を人工的に抏こし，これに前述した如く約

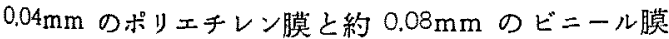
により閉鎖して C.M. の変化を観察した.

第 45 図恃攱膜の前下 $1 / 4$ の部分に 穿孔を 作つたもの である。この $1 / 4$ 穿孔では $3000 \mathrm{c} / \mathrm{s}$ までは大体 $15 \mathrm{db}$ 前後の損失であり高音にゆくに従つてその損失山俥度と
圆 44

鼓膜剩蜼

No. 1

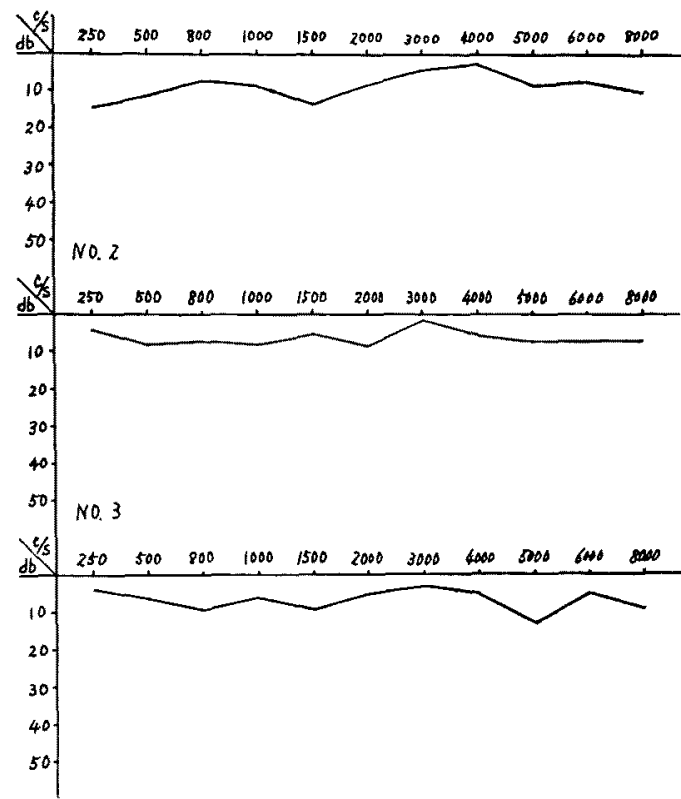

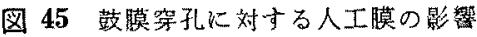
$1 / 4$ 穿 孔

$$
\begin{aligned}
& \text { —穿 孔 } \\
& \text { - - - }
\end{aligned}
$$

No. 1

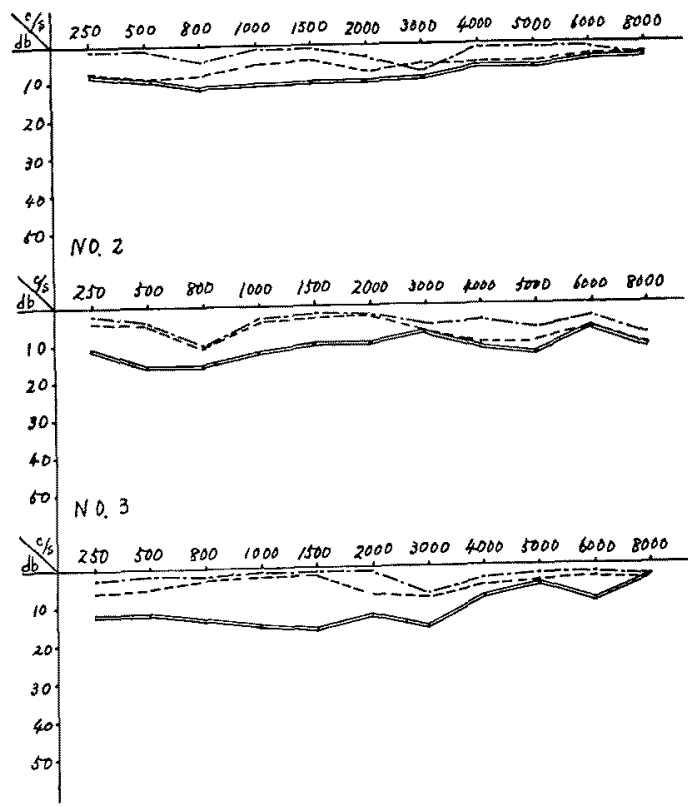


图 46 敨膜穿孔に対する人工膜の影瑤

$$
1 / 2 \text { 穿 孔 }
$$$$
\text { ーーーーポリエチレン膜 }
$$

No. 1

แแแนแแแณ ビニール膜

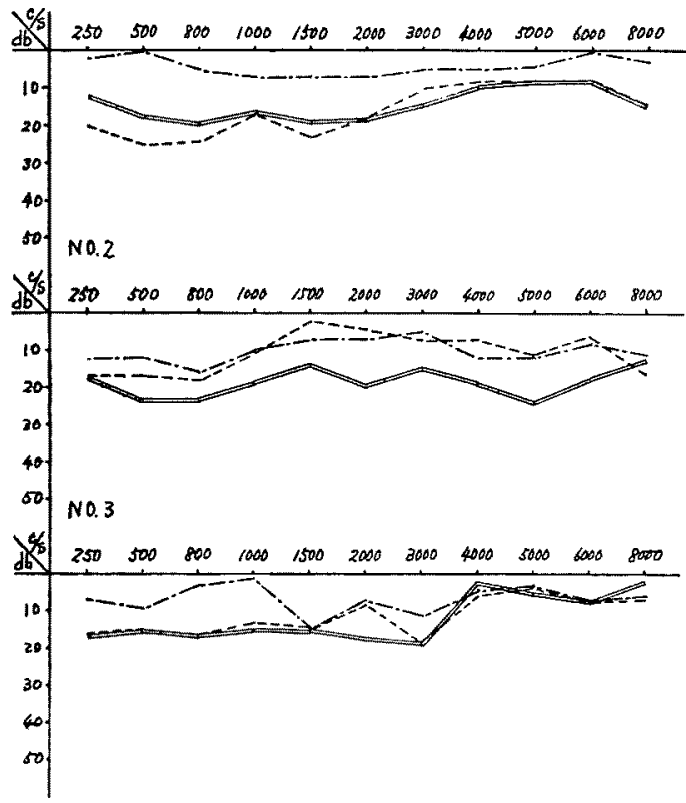

なる.これに対してらすいポリエチレン膜で閉鑜すると

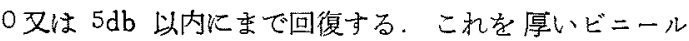
膜で閉鎖するとその差は僅かではあるが愿いちが回復が 墨く，特に高音部において顕著である，この場合膜の質 量の変化と緊張度の減少が䒓觉られる。

次の第 46 図は1/2穿孔の場合である。この場合の C.M. の変化は1/4穿孔の際よりもその損失が大で 20 $\mathrm{db}$ 前後の損失を示している。薄い膜は厚い膜よりる等 孔閉鏡をした際 C.M. の回復が良好である事は1/4等 孔の場合と同様である。しかし1/4穿孔に比して雨者之 も穿孔前の值なで回復し難くなり䑏の厚さの差が強くあ らわれてきている，穿孔が大になりその上に人工膜をの せればその膜の祭張は瑟くなるに違いなく，その摆向を この data は示していると考觉られる，穿孔閉鎖に対寸 る影響は低音域につよい，故に伝音障碍である慢性中耳 炎の鼓室成形術啳に和いて低音域，中去域の变動の大き い事は納得がゆくこの変化に比べ扎ば高音域の変化は 少く膜の性質によつて余り影響奴なが高音の回復はや や瑮くなるようである。

第 4 節 小 括

鼓膜の変化及び耳小骨周囲の変化を害験的に作り上げ
て観察した、いずれむ臨休例の観察結果から推定され代 る条件である。

植皮片のはり方，術中の肉芽除去操作及び術後の創低 治疻機転によつて正常鼓膜と人工鼓膜に差が生して、 る、又耳小骨周囲の結合組織の增生も考えられるため ある。しかしいずれもが先つ低音域の障碍をきたし，忐

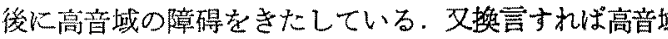
が低下してきている場合は既にとれより高度の低音障石 お存在している。

本䒠験条件では高音域のみの障碍を伝音系の障碍だ で作り出すのは不能であつた。

\section{第 IV 章 緢括並びに考按}

鼓室成形術は中耳伝音采の再修復によつて良好な聴う を期待する手術であるが，前術で述べだ如く高音域のた 復は困難であり，軽度ではあるが術後かえつて低下す。 症例孔事実存在している，中耳伝音系の障碍が低音域 び中音域の周波数の聴取能力に非常な影響を与える事け よく知られているが，高音域に対しては比較的变化が少 いと言はれているてかし高音の回復は決して不可能子 はなく全周波数にわたつて改善される症例る数多く存存 し，この手術に対する期待を蛪ぎらない，それでる低声 域及び中音域が改善されたにも拘らず，高音域のみが己 善されない症例が存在し，これらの症例は高音の改善に 何らかの不都合な条件が存在するに違いないのであるか 明確な解答を見出せなかつた。しかしこれらの症例群い 非常に㑮かである。

骨導聴力值が内耳の侵能の一部分を表現しているとす れば，高音に対する骨導聴力低下例は純粋の伝音系障确 とは考えられない，純粋の伝音系障㥂によると考光られ る高音域のみの改盖不良の蹦床例の検討によつては全く 一定の共通点を認め難い，これらの症例群のあるるのけ 三耳小骨残存例であり，又あるものは再手術例である。 枝膜案孔は中等大の穿孔多く術中観察した病变も比較的 軽庭である。

一般に中耳の機能は 1) 空気と外淋巴液の固有性を一 ソチさせ，2）振動起との形のまま最小限の变化で伝播 させ，3）更に内耳椪造に対する保護作用をなしている この中耳伝音系を構成する要素としては，穜膜，耳小骨 連鎖（棺砧体，砧鐙関節，鐙骨，諸筇肉，刺带)，中耳 腔，乳様洞，乳様蜂简等が関与し，更病的中耳伝音忒 はこれに炎症性変化に基つく結合織，中耳腔液体の䀧 溜，中耳腔の内王の変化等々の相乗因子が附加される一 方でこの分析は全くもつて至難である。 


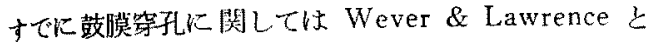
その学派達によつて動物实焕の結果が我々に与えられて いる.

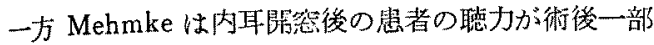
低下してくるところからこの原因を鼓膜にあると考光， 敋膜に負荷を与えることによつて解決できたと述べてい る、彼はこの原因を驰緩した鼓膜が負荷によつて再びェ ネルギー伝達力をるつた円錐として振勘することによる のだと解釈した。

Heermann jr. は Fascienplastik 㳊関する彼の論文 の中で術後の高音の改善の悪さは内耳障碍ではなく卵円 䓡上をる mass のインピーダンスによるものであり， 赫後の経過化よつて良好な結果をたどるのはコルメラの 接解点と鐙骨板，鼓膜とが強固に結びつき円錐形にはつ た豉膜の祭張がより良好になるのだとしている，又更に Mehmke は故膜前後の音王を測定して鼓膜穿孔による 音王の変化を探究し，穿孔纪よる変化は低音部が大で $1000 \mathrm{c} / \mathrm{s}$ で㱠んど变化なく $5000 \mathrm{c} / \mathrm{s}$ で雨び增加するの を見出した．そしてこれは新鮮な鼓膜穿孔を有する人間 にもあてはまると述べている，我々の臨床例を一見して みて特に高音のみが低下する原因は術前及び術中の手術 所見からはそのような区子の存在は考えられない，鼓膜

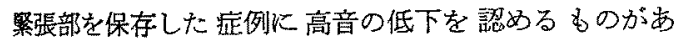
るが, Cancura \& Schwetz の実験によれば嗢膜弛緩 部の穿孔による影響は皆無に近く、緊張部50\%の穿孔で $25 \mathrm{db}$ の損失だと述べている.

モルモットの散膜虽離突験で 3 例之も水平型 $10 \mathrm{db}$ 前後の損失を見，高音のみの低下は認められなかつた。 次に行つた攱膜穿孔の修復では穿孔小さく薄い膜ではつ た場合は正常値近くまで回復したのに反し，穿孔やや大 きく㝵いビニール獏ではつた場合は小等孔よりも全体に 回復瑟くその状態土特に高音が悪い結果となつた。がこ の場合同時江低音域の低下もあり高音のみの低下の原因 とはなり難い。

耳小骨連鎖の振動特性については高音域に関与すると 言う Zowy，低音域伝音比役割を有すると言う Bezold， 全音城にわたり伝音すると言う Dahmann, Pohlmann， Wever, 浮田等の報告がある. 佐藤 (隆) は中耳癒着化 上る砧鐙関節肉芽性連鎖の症例について観察し，特異的 I stiffness control を示したところからこの原因を肉

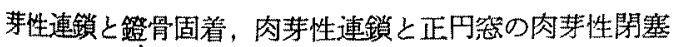
に起因する異常反応と見なした．Campbell によれば鐙 骨固着の初期聴力像は鐙骨が蝸牛款の一部となり siiff- ness が附加されて mass control となり高音低下が更 は加はり平均化すると言う。.Schambough も同様な見 解を述べている。

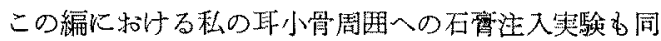
棁な結果を示した，即ら石望が少しやわらかい場合は先 づ低音のみが障碍されて低音涂降型となり，石骨の硬さ を增すに従つて高音低下が加つてくる．このため聴力像 は平均化されたものになり，特信音のみを低下させる 因子とはなっていない，我及の臨床例から之りあげた慢 性中耳炎の㾤着症例では大部分に高音に批々る骨導聴力

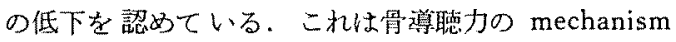
から言っても当然の事ではあるか，このような病変をひ きおこした症例去術後に高音部が回復し難い事を推諭で きる、この第一の原因は鐙骨の運動不良にあると考之 る、䡩微鏡使用に上る手術操作とは言光，鐙骨に対する 操作は特に揁重を要求される点であり，完全に正常に近 い状態まで復し得ず病变の残存も充分に考兄られるから である。

H.G. Andersen は耳手術後にその連鎖の欠損状態に 従つてポリェチレン管とか双は骨の小片を挿入すること によつてその術後德力が 低中音は非常に回復するのに $2000 \mathrm{c} / \mathrm{s}$ 以上の高音の回復の悪い事定認めている. 更に これを实験によつて証明するため音進行の逆経路で音圧 の測定を行い conducting mechanism における mass の增加は高音に対しては必ずしも必須の条件ではないと 推諭している.そして插入した Prothese の位置が渄常 に重要であり良好な聴力を得るためには何度も trial and error method を行うべきだとしている.

更に最近 Stapesplastik 後の高音域の反応がとりあ げられて扣り，Stenger は Stapesplastik 後の高音低 下についてその原因を三つあげている，即ち

1）鼓膜の復元力の減少

2) 連鎖の Federkraft の減少

3) 附䯣的な mass の負荷である

これらの条件はすべて手術後の耳に生ずる状態として 考えられるべきものであるが，高音のみの損失に対して は mass の增加, 復元力の減少を挙げている.

又 Schwetz \&同様炕 Stapesplastik 後の高音低下に ついて検索して和り，連鎖の Steifkeit の術後の減少を 問題にし，これにはは途中に存在する組織の状態が関係あ ると述べている．以上は大体 Stapesplastik 後の聴力に 関しており慢性中耳炎によるものでないため，いつれも 鐙骨の操作に重点が抬かれ論ぜられている。しかしその 
論点杂特に新しくなく常識的に述べられているように感 じられる．たしか取小骨連鎖は術後その所謂 Steifkeit が変化し，その差が高音に対する反応として現は れてくる事性考党られるが，これら一つ一つの条件忏術 後に生し得るすべて考觉られる条件である。これらを集 積している鼓室成形術後の聴力を一つ一つ解明する事は 非常に困難であり，鼓室成形術に和ける高音低下に対し てただらにあてはめる事はできない，

教室の梅垣は全く別の見方から腔体变化に上る音圧变 動について観察し，鼓室成形術後の乳様洞を含めての腔 体に対し模型及び人頭蓋骨による実験を施行して腔体の 変化と聴力変動を観察した．その結果低下周波数の波長 $\lambda$ と側管距離 $\ell$ は

$$
\ell \div \frac{1}{4} \lambda
$$

の関俰あことを見出し，これらの現象学波動理論上入 射波と反射波の重鲳現象として説明している．このため 外耳道を保存し上鼓室及び固有鼓室のみ操作を加立， 植皮片で㠅つた症例を 1 年間の症例中よりえらび出し観 察したところ，高音の回复は低，中音域に比べて悪い結 果を示した．この場合の腔体変化は殆んど僅かであり， 側管距離は無視し得る。この事実より考えると実際の臨 床例に佂いてはこの寒験の結果をあてはめて説明する事 はできない

散室成形術後の高音の回復不良な状態は各々の症例に よつて異り，今迄挙げられてきた条件が種々の形で関与 していると考亲るのが現在の状態である.

実際上鼓膜の復元力の減少については臨床例に执いて 散膜緊張部保存例及び耳小骨保存例のみ高音の回復不 良状態を認めてはいないが長期間後に高音が変化し回復 してゆく経過をとるところから，術創の安定と共に新生 膜の緊張が增加したと考えたい．

又次に鐙骨附近の变化も高音低下の一因と考光られ る、耳小骨周明の操作によつて肉芽或いは結合織の增生 が括こり，mass の負荷が括こるのは当然である。

しかし最も重要な点は新生障膜である。臨床例の観察 ではこの新生膜の振動様式や振動特性を実証する事は困 難であり，実験的研究に括いてもこの問題に対しては満 足すべき結果は未だ得られていない。

正常豉膜とは全く別の特性を持つているに違いなく， 外耳道保存症例に括壮る高音回復不良の状態はこの新生 膜の性質を示していると考充る，術後短時日に和ける高 音の変動の著しさ，長期間にわたる高音の回復，これら
によつて高音の回復不良は新生膜自身の性質によるもの であろうと推察する. そして 1 年後, 2 年後倍高域の 改善が認められるのは肉眼的所見からも推察し得るよう に新生膜の復元力の增加と考えてよいのではなからう か.

\section{第 $\mathbf{V}$ 章 結 論}

伝音障碍による高音低下について追求した。臨床例及 びモルモットを使用して実駼を行い钼察した結果次の如 き結論を得た。

鼓室成形術においては高音域の回復不良な症例がかな り多く認められるが，低音域，中音域の上昇之高音域の 回復不良を同時にあわせ持つ症例は余り多くない.これ らの症例群を比較検討すると，約50\%に高音域の骨導聴 力低下が認められる他は, 病変軽度で三耳小骨を残し得 た症例が多く，このため連鎖操作と高音域の聴力変動の 関保も断言できない，又腔の搪大による影響も䠛床例で は認められす新生膜の形成と共に回復する.

实騟の結果から鼓膜の緊張の減少厄上る高音域の低下 は常に低音域の障碍を伴い，石望の硬化，即ち硬い肉茅 の出現は高音域を障碍する事を推定できる.

\section{第 VI章 全編の総括並び結論}

1951 年欧州に括いて Wullstein, Zöllner 等が伝音 系修復の問題をとりあげ，1952年我が国において後藤 教授がこの問題に着手して以来, 鼓室成形術は種々の段 階を経て今日に至つている. 現在では聴力玫善の問題の みでなく，新生膜穿孔，耳漏停止の困難な症例等の問題 まで検討されている．即ちこの事は㛺室成形術が従来ま で行はれてきた根治手術より現在では広く行はれるより になつた事を示している。

伝音系の修復に関しては C.M.を指針とした実騟によ つてその mechanism は徐々に解明され正常に括ける 場合の状態峌る程度まで理解されている，しかし病的 变化の場合特に術後聴力の問題，新生膜の問題について は末だ殆てど解決されてはいない。

本研究は名大耳奥咽知科教室で施行した鼓室成形術淀 例群の術後聴力像について種くの点より観察すると共

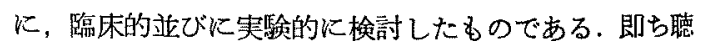
力像を術後短時日より镜察し, 退院後, 1 年後, 2 年後 と聴力の変動を研究した。 そして亄室成形術はどのよう な手術型をとるのが理想的か，聴力安定の時期は何時と 考えるべきか，術後の周波数移動はなんKよつて決定さ れるか等について検討したものである。

その結果 
1) 会話領域の周波数の聴力閥値は術後 1 年位で安定 すると考克られる，但し低音域，高音域は更に変化し易 く, 両者の変化け相反している。

2）健全な耳小愲連鎖を除去する之術後聴力は低下を きたし易い。

3）連鎖保存例に実用聴力を有するものが多い。

4）連鎖消失の鐙骨残存例は術後聴力変動が良好なる あのが多い。

5）鼓室成形術施行例の約半数が実験值に近似する聴 力像を有し，しからさる症例は三耳小梋保存例に多く， 術後厄叔りる耳滑連鎖機能について一考を要する。

6) 術直後の気導聴力は殆んど低下を示すが術創の乾 燥と共江聴力生改善される。

7) 術前気導聴力 $60 \mathrm{db}$ 以上のものは術後の改善は 期待乙難い，

8）豉室成形術後の高音低下の原因を一つの因子に限 定する事恃困難であるが，回復不良の因子として新生膜 の特性を考克得る。

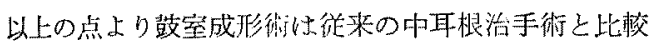
して非常にすぐれて居り，病变の程度によってそれに適 した伝音形態子悠復し得る。このため比較的軽度の病変 の存在する症例であつても手術は可能であり，その術 後㯖力む低下を来ちこと少く，たと京高音低下を生じて る改善される希望を持ち得るるのである.

ここに括いて敖室成形術を施行するにあたつては，先 つ第1 1 炎症の消失以努力せ小ばならない，何故ならば 炎症の存在によつては聴力改善は望を机ないからであ る.

第2に健全なる耳五骨連鎖はできる限り残存すべきで ある，䱦全なる速鎖を除去した場合の術後聴力の改善状 態悪く，連鎖を保存した症例に比して退院時では大差 が認められなくとも遠隔成繢で差異を認めることが少く †い.

今後我々に解沃を要求せられる問題は創傷治瘉後の耳 に淤る耳小骨連鎖の状態及び新生鼓膜の特性である。

\section{琴考文献}

1) Andersen, H.C., Jepsen, O. \& Ratjen, E.: Ossicular-chain defects, diagnosis and treatment, Acta Oto-Laryng., 54; 393, 1962.

2) Dingley, $A$.

R.: Some limitations of radical mastoidectomy and the value of early conservative surgery, J. Laryng. \& Otol., 69; 361, 1955. 3) Flock, H.: Hörverbes. serunde Operationen (und andere Beobachtungen) an einer Schwerhörigenschule, Arch. Ohr.-, Nas.-, u. Kehlk.Heilk., 180；282, 1960 . 4) 傒藤修二:

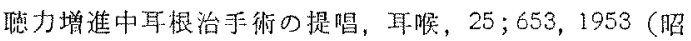

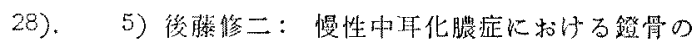

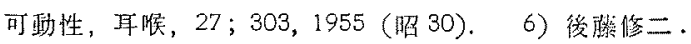
㯖力堌進中耳手術汇ついて，耳喉，27；187，1955（昭

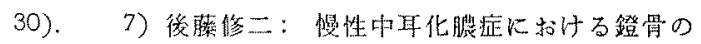
状態，耳喉，28；159，1956（昭 31). 8) 後藤㤏二： 聴力改善手術の進步，耳喉，26；617，1954（昭 29）.

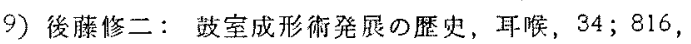
1962 (昭 37). 10) 後櫒修二, 板食 秀: 中耳形成

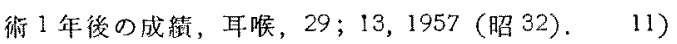
後藤修二，梅垣炤一：䔩室成形術後の胵体变化に上る 音胿变動について，日耳鼻総会号，63；612，1960（昭 34). 12) Goodhill, V., \& Holcomb, A.L.: The relation of auditory response to the viscosity of tympanic fluids, Acta Oto-Laryng., 49; 38, 1958.

13) Goodhill, V.: Theoretical aspects of stapes mobilization, A.M.A. Arch. Otolaryng., 71; 248, 1960. 14) Guilford, F.R.: Certain problems in tympanoplasty, Ann. Otol. Rhin. \& Laryng., 68; 838, 1959. 15) Hjorth, S., Lundborg, T. \& Rösler, G.: Zum Schalleitungsmechanismus des Mittelohres, Acta Oto-Laryng., 50; 423, 1959.

Heermann jr., H.: Trichterförmige Fascienplastik des Trommelfells aus mehreren Stücken mit Knorpelbrücke zum Stapes nach Radikaloperation des Ohres und das Gehör bei dickern Trommelfell, Arch. Ohr.-, Nas.-, u. Kehlk.-Heilk., 180; 556, 1962. 17）板会秀：㯖力增進手術の邀隔成斑とその予後，第 16 回日本医学総会学術檴演筑，日本医学の1963 年版, 1；791，1963(昭 38).18) 池田宏：頭部及び外耳 道の㯖力に及注す作用の矿究，日耳身，62；1464，1959 （昭 34）。19）河辺㼁荐：中耳根治手術後の聴力に及

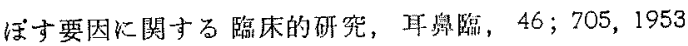
(昭 28)。20) 加藤隆：中耳伝音障碍の蜛牛電気反応

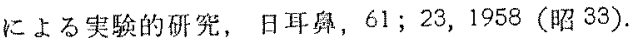

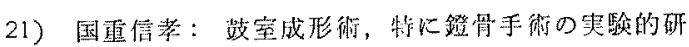
究，日耳舅，63；2176，1960（昭 35).22）柏戸贞一： 耳小骨連鎖の機能比閣する䂯究，日耳宊，66；14，1963

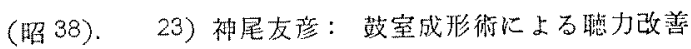
について，耳皖，34；953，1962（昭37）。24) 風問保

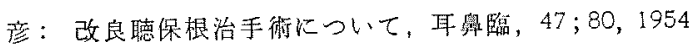


(嘴 29).

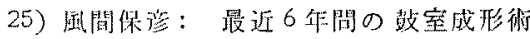

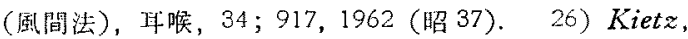
H.: Die Amplitudenverhältnisse; Trommelfell, Stapesfussplatte und Basilarmembran, Arch. Ohr.", Nas.-, u. Kehlk.-Heilk., 175; 361, 1959. 27) Laurence, $M$. Applied physiology of middle ear sound conduction, A.M.A. Arch. Oto-Laryng., 71 ; 133, 1960. 28) Laurence, M.: Process of sound conduction, Laryngoscope, $68 ; 328,1958.29)$ Laurence, M. \& Wever, E.G.: Recent investigations of sound conduction, Ann. Otol. Rhin. \& Laryng., 59; 1020，1950. 30) 丸山正夫：中耳根治手術の術後聴 力に及活す影響について，耳喉，23；290，1951(昭26). 31）松岡哲郎：中耳根治手術上㯖力に関する研究，日

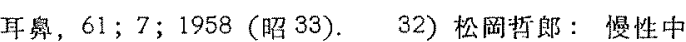
耳炎のオージオグラム，日耳舆，61；560，1958(昭34). 33）松岡焎郎：中耳根治手術と術後聴力に関する研究， 日耳医，61；658，1958（昭 34）。35) 松岡哲郎：中

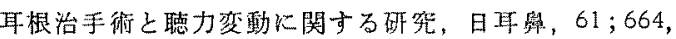
1958 (昭 34). 36) Mehmke, S.: Hörverbesserunde Massnahmen an spannungsveränderten Trommelfell, HNO, 7 ; 296, 1959. 37) Mehmke, S.: Der Hörverlust bei der Perforation des Trommelfells, $Z$. Laryng. Rhinol., 41 ; 669, 1962. 38) 西端八郎: 慢性中耳炎根治手術㓣の治臆機転に関寸る研究, 日耳

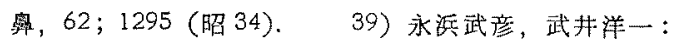
Tympanoplastik による㙏力の変化について, 日耳囷， $60 ； 1431 ， 1957$ (昭 32).40) 大和田健次郎：最近の

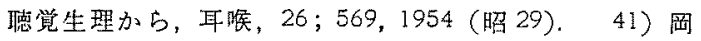
部一男: 耳模型に上る中耳伝音器の实験的研究，日耳

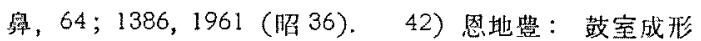
術の伝音理諭，耳烼，34:837，1962（昭 37)。 43）恩

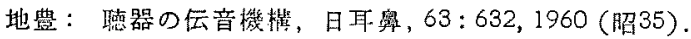

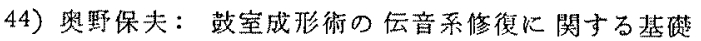
的研究，日耳鼻，64:1538, 1961 (昭 36). 45) Palva, T. \& Pulkkine, $K$ : Hearing after surgery in chronically discharging ears, Arch. Otolaryng., 52; 175, 1960. 46) Rahm, Jr., W.E., Strother, W.F., Lucchina, G. \& Gulick, W.L.. The effects of air pressure on the ear, Ann. Otol. Rhin. Laryng., 57; 170, 1958. 47) 佐藤隆三：中耳インピーダンスに関

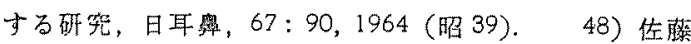
智子：菠室成形術㣪の聴力に関する研究，日耳，60， 576,1957 (昭 32).

49）佐藤清：耳科手術による聴
力の変動に閉する研究，日耳率，59，1537，196(昭31)。

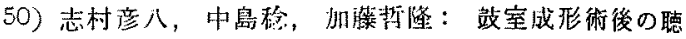
カについて，日耳舅総会号，63：616，1960(昭 35).

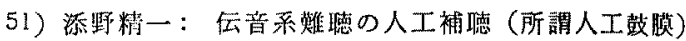

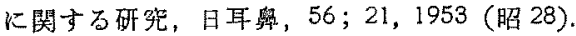

Singleton, H.F. \& Schuknecht, H.F.: Experimental fracture of the stapes in cats, Ann. Otol. Rhin. \& Laryng., 68; 1069, 1959.

53) Simmons, F.B.:

Middle ear muscle activity at moderate sound levels, Ann. Otol. Rhin. \& Laryng., 68; 1126, 1959. 54) Schwetz, F.: Das Absinken der Hörkurve im höheren Frequenzbereich nach Stapesplastik, Arch. Ohr.-, Nas.-, u. Kehlk.-Heilk., 179; 545, 1962, 55) Stenger, H.F.: Über den schalleitungsbedingten Hochtonverlust nach der Stapesplastik, Arch. Ohr.", Nas.-, u. Kehlk.-Heilk., 181；573，1963， 56) 角田 忠信；鐙骨固着度の検出法，日耳鼠，59；1939,1956 (昭 31)，57) 土田登：埕公成形術の実験的研究，日 耳鼻，62；2199，1959（昭 34)。 58) Wullstein, H. L.: The surgical restoration of hearing in chronic otitis media and its audiological basis, Ann. Otol. Rhin. \& Laryng., 67; 952, $1958 . \quad 59)$ Wullstein, H.L.: Eustachian tube in tympanoplasty, Arch. Otolaryng, 71; 329, 1960 . 60) Wullstein, H.L.: Principles of tympanoplasty, A M.A. Arch. OtoLaryng., 71; 329, 1960. 61) Weegers, H.: Sch. wierigkeiten bei der Tympanoplastik, HNO, 7; 189, 1959. 62) Weichselbauer, W.: Ergebnisse der Tympanoplastik bei Kindern und Jugendlichen, Arch. Ohr.-, Nas.-, u. Kehlk.-Heilk., 180; 273, 1962.

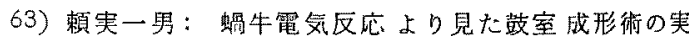

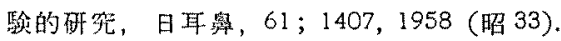

Zöllner, F.: Hörverbesserunde Operation bei entzündlichbedingten Mittelohrveränderungen, Arch. Ohren-usw. Heilk. u. Z. Hals.usw. Heilk., 171; 1, 1957.

稿を終るに臨み御指導御校閲を睗つた恩師後 藤修二教授に霔心より感謝致します、また本政 宎の实験に際して終始御指導をいたざいた楮村 博士に深く感謝の意を率げると其に，直接学を 法にし御侐撻下さつた今泉学士始め，絶大なる 御助力を贔つた教室買各位に感謝致します。

本諭文の要旨は第156回，157回，168回， 169 回, 170 回, 174 回, 175 回，190回，191 回の各東海地方会に招いて発表した。

（原稿到着=昭和 39.8 .28 日一急載) 